Eastern Illinois University

The Keep

Masters Theses

Student Theses \& Publications

1971

\title{
Tungsten Carbonyl Complexes Containing Positively Charged Phosphorus Ligands
}

Dilip Poonamchand Shah

Eastern Illinois University

This research is a product of the graduate program in Chemistry at Eastern Illinois University. Find out more about the program.

\section{Recommended Citation}

Shah, Dilip Poonamchand, "Tungsten Carbonyl Complexes Containing Positively Charged Phosphorus Ligands" (1971). Masters Theses. 3953.

https://thekeep.eiu.edu/theses/3953

This is brought to you for free and open access by the Student Theses \& Publications at The Keep. It has been accepted for inclusion in Masters Theses by an authorized administrator of The Keep. For more information, please contact tabruns@eiu.edu. 
TO: Graduate Degree Candidates who have written formal theses.

SUBJECT: Permission to reproduce theses.

The University Library is receiving a number of requests from other institutions asking permission to reproduce dissertations for inclusion in their library holdings. Although no copyright laws are involved, we feel that professional courtesy demands that permission be obtained from the author before we allow theses to be copied.

Please sign one of the following statements.

Booth Library of Eastern Illinois University has my permission to lend my thesis to a reputable college or university for the purpose of copying it for inclusion in that institution's library or research holdings.

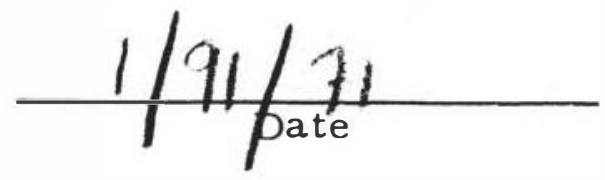

I respectfully request Booth Library of Eastern Illinois University not allow my thesis be reproduced because 
Tungsten Carbonyl Complexes containing

Positively Charged Phosohorus Ligands (กITLE)

BY

Dilip Poonamchand Shah

B.S. $(1966)=$

The University of Bombay

Bombay, India

THESIS

SUBMITTED IN PARTIAL FULFILLMENT OF THE REQUIREMENTS

FOR THE DEGREE OF

Master of Science

IN THE GRADUATE SCHOOL, EASTERN ILLINOIS UNIVERSITY CHARLESTON, ILLINOIS

1971

YEAR

I HEREBY RECOMMEND THIS THESIS BE ACCEPTED AS FULFILLING

THIS PART OF THE GRADUATE DEGREE CITED ABOVE

$\frac{1 / 15 / 71}{\text { DAIE }}$

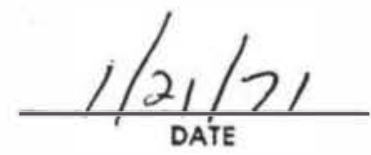


IUNGSTEN CAPBONY COMPLEXES

CONTAINING POSITIVELY CHARGED

PHOSPHORUS LIGANDS

BY

\author{
Dilip Poonamchand Shah \\ Bachelor of Science \\ The University of Bombay \\ Bombay, India \\ January. 1966
}

\footnotetext{
Submitted in partial fulfillment of the requirements for the degree of

Master of Science in Chemistry at the

Graduate School

of

Eastern Illinois University
}

CHARLESTON, ILLINOIS

1971 


\section{TUNGSTEN CARBONYI COMPLEXES}

CONTAINING POSITIVELY CHARGED

PHOSPHORUS LIGANDS

Thesis Approved

Dr. R. L. Keiter. Thesis Advisor

Dr. D. W. Ebodon

Dr. R. H. Karraker 
DEDICATION

To my liother and Father

iii 
Tho author expresses his sincere appreciation to $\mathrm{Dr}$. Richard Koiter for suggesting the problem and for providing galdance, inspiration and assistance throughout the invest. igation.

The author would like to give thanks to other members of the faculty, especially Dr. J.W. Ellis, for their active interest and help.

The author wishes to thank Varian Associates for their assistance with the phosphorus-31 nmr spectra, Mr. Paul Bork for his drawing of a uv cell and Nirs. Ellen Keiter for typing this manuscript.

Gratoful acknowledgement is also made to the Eastern Ilinois University Research Grant Cormittee for their support. Special thanks are in order for the author's wife, Pinkey, who has provided, not only very appreciated encouragement, but also invaluable aid in typing the rough draft of the thesis. 


\section{TABLE OF CONTENTS}

Chapter

I Introduction.........................1

II Results and Discussion...................14
A. Synthetic Aspects...................14

B. Theoretical Aspects.................21

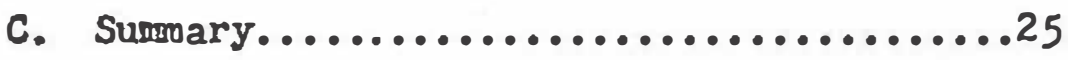

III Experimental.......................27

A. General Considerations ...............27

B. Preparation of Iigands..............28

C. Preparation of Neutral Complexes........31

D. Preparation of Positively Charged

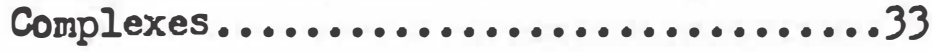

E. Attempted Preparations..............35

Bibliography..........................66

Appendix I Computer Program for Calculation of Force Constants...............66 68

Appendix II Drawing of uv Cell................?0 


\section{LTST OF FICURES}

Figure

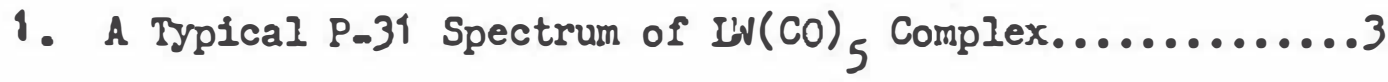

2. Co Stretching Region of the Infrared Spectrum of a

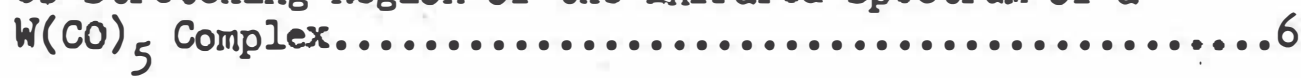

3. Nmr Spectrum of $\left(\mathrm{C}_{6} \mathrm{H}_{5}\right)_{2} \mathrm{PCH}_{2} \mathrm{CH}_{2} \mathrm{P}\left(\mathrm{C}_{6} \mathrm{H}_{5}\right)_{2} \ldots \ldots \ldots \ldots . . \ldots 38$

4. Nmr Spectrum of $\left(\mathrm{C}_{6} \mathrm{H}_{5}\right)_{2} \mathrm{PCH}_{2} \mathrm{P}\left(\mathrm{C}_{6} \mathrm{H}_{5}\right)_{2} \ldots \ldots \ldots . . \ldots \ldots . . \ldots 39$

5. Expanded Infrared Spectrum of $(\mathrm{CO})_{4} \mathrm{Bri}\left(\mathrm{C}_{6} \mathrm{H}_{5}\right)_{2} \mathrm{PCH}_{2-}$ $\mathrm{CH}_{2} \mathrm{P}\left(\mathrm{C}_{6} \mathrm{H}_{5}\right)_{2}\left(\mathrm{CH}_{2} \mathrm{C}_{6} \mathrm{H}_{5}\right) \ldots \ldots \ldots . . \ldots \ldots$

6. Expanded Infrared Spectrum of $(\mathrm{CO})_{4} \operatorname{Briv}\left(\mathrm{C}_{6} \mathrm{H}_{5}\right)_{2} \mathrm{PCH}_{2}{ }^{\mathrm{P}}\left(\mathrm{C}_{6} \mathrm{H}_{5}\right)_{2}\left(\mathrm{CH}_{2} \mathrm{C}_{6} \mathrm{H}_{5}\right) \ldots \ldots \ldots . . \ldots . . .41$

7. Nom Spectrum of

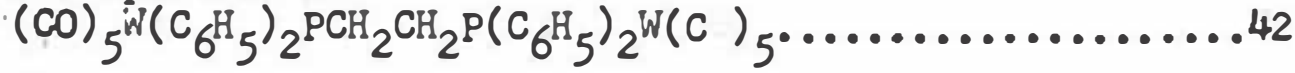

8. Nmr Spectrum of

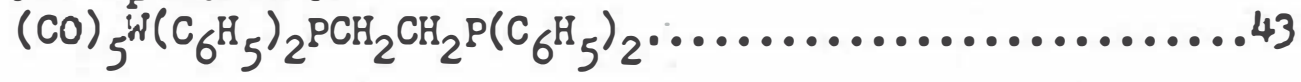

9. Nomr Spectrum of $(\mathrm{CO})_{5}{ }_{\mathrm{W}}\left(\mathrm{C}_{6} \mathrm{H}_{5}\right)_{2} \mathrm{PCH}_{2} \mathrm{CH}_{2} \stackrel{+}{\mathrm{P}}\left(\mathrm{C}_{6} \mathrm{H}_{5}\right)_{2}\left(\mathrm{CH}_{2} \mathrm{C}_{6} \mathrm{H}_{5}\right) \mathrm{Br} \ldots \ldots \ldots \ldots . . \ldots 44$

10. Expanded nor Spectrup of (CO) ${ }_{5} \mathrm{~W}\left(\mathrm{C}_{6} \mathrm{H}_{5}\right)_{2} \mathrm{PCH}_{2} \mathrm{CH}_{2}{ }^{\mathrm{P}}\left(\mathrm{C}_{6} \mathrm{H}_{5}\right)_{2}\left(\mathrm{CH}_{2} \mathrm{C}_{6} \mathrm{H}_{5}\right) \mathrm{Br} \ldots \ldots \ldots \ldots . \ldots . . \ldots 4$

11. Nmr Spectrum of
(C ) ${ }_{5} \mathrm{WP}\left(\mathrm{C}_{6} \mathrm{H}_{5}\right)_{2} \mathrm{CH}_{2} \mathrm{CH}_{2} \stackrel{+}{\mathrm{P}}\left(\mathrm{C}_{6} \mathrm{H}_{5}\right)_{2} \mathrm{CH}_{2} \mathrm{C}_{6} \mathrm{H}_{5} \mathrm{PF}_{6}^{-} \ldots \ldots \ldots . \ldots . . .46$

12. Nmr Spectrum of $(\mathrm{CO})_{5}{ }^{j \mathrm{~N}}\left(\mathrm{C}_{6} \mathrm{H}_{5}\right)_{2} \mathrm{PCH}_{2} \mathrm{P}\left(\mathrm{C}_{6} \mathrm{H}_{5}\right) \ldots \ldots \ldots . . . .4$ ?

13. Nmr Spectrum of

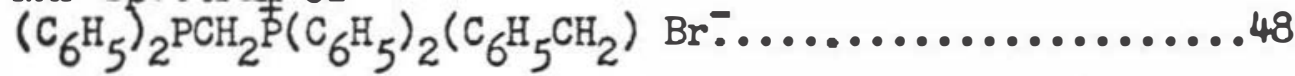

14. Nmr Spectrum of $\left(\mathrm{C}_{6} \mathrm{H}_{5}\right)_{2} \mathrm{PCH}_{2}{ }^{\mathrm{P}}\left(\mathrm{C}_{6} \mathrm{H}_{5}\right)_{2} \mathrm{CH}_{3} \mathrm{I} \ldots \ldots . . . \ldots . . .49$

15. Nmr Spectrum of (C ) ${ }_{5} \mathrm{~W}\left(\mathrm{C}_{6} \mathrm{H}_{5}\right)_{2} \mathrm{PCY}_{2}{ }_{\mathrm{P}}^{+}\left(\mathrm{C}_{6} \mathrm{H}_{5}\right)_{2} \mathrm{CH}_{3} \mathrm{I} \ldots \ldots . . . .50$

16. Expanded Spectrum of

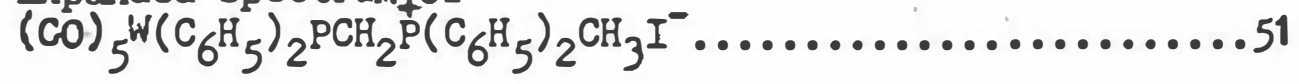


17. Nmr Spectrum of $\left(\mathrm{C}_{6} \mathrm{H}_{5}\right)_{2} \mathrm{PN}\left(\mathrm{C}_{2} \mathrm{H}_{5}\right)_{2} \ldots \ldots \ldots \ldots \ldots \ldots \ldots . . \ldots \ldots$

18. Expanded nnr Spectrum of $\left(\mathrm{C}_{6} \mathrm{H}_{5}\right)_{2} \mathrm{PN}\left(\mathrm{C}_{6} \mathrm{H}_{5}\right)_{2} \ldots \ldots \ldots \ldots . . .53$

19. Nmr Spectrum of $(\mathrm{CO})_{5}{ }_{5}\left(\mathrm{C}_{6} \mathrm{H}_{5}\right)_{2} \mathrm{PN}\left(\mathrm{C}_{2} \mathrm{H}_{5}\right)_{2} \ldots \ldots \ldots \ldots \ldots . \ldots \ldots$

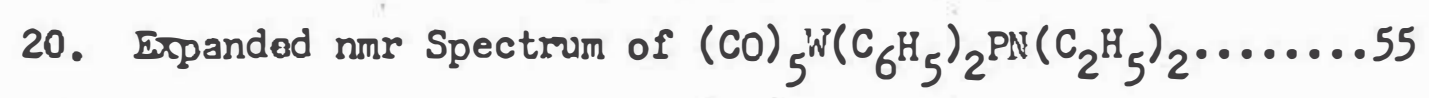

21. Infrared Spectrum of $\mathrm{W}(\mathrm{CO})_{5}\left(\mathrm{C}_{6} \mathrm{H}_{5}\right)_{2} \mathrm{PH}\left(\mathrm{C}_{2} \mathrm{H}_{5}\right)_{2}+{ }^{\mathrm{H}}(\mathrm{CO})_{5}\left(\mathrm{C}_{6} \mathrm{H}_{5}\right)_{2} \mathrm{P}_{\mathrm{N}}\left(\mathrm{C}_{2} \mathrm{H}_{5}\right)_{3} \mathrm{BF}_{4}^{-}(?) \ldots 56$

22. Infrared Spectrum of $\mathrm{W}(\mathrm{CO})_{5}\left(\mathrm{C}_{6} \mathrm{H}_{5}\right)_{2} \mathrm{~F}^{\mathrm{PN}\left(\mathrm{C}_{2} \mathrm{H}_{5}\right) 2^{\mathrm{BF}}-\overline{4}}+\mathrm{W}\left(\mathrm{CO}_{5}\left(\mathrm{C}_{6} \mathrm{H}_{5}\right)_{2} \mathrm{PN}\left(\mathrm{C}_{2} \mathrm{H}_{5}\right)(?) \ldots 5 ?\right.$

23. Expanded Infrared Spectrum of $W(\mathrm{CO})_{5}\left(\mathrm{C}_{6} \mathrm{H}_{5}\right)_{2} \mathrm{PCH}_{2} \mathrm{CH}_{2} \mathrm{P}\left(\mathrm{C}_{6} \mathrm{H}_{5}\right)_{2} \ldots \ldots \ldots \ldots \ldots \ldots \ldots \ldots \ldots \ldots \ldots \ldots \ldots \ldots \ldots \ldots \ldots$

24. Expanded Infrarod Spectrum of

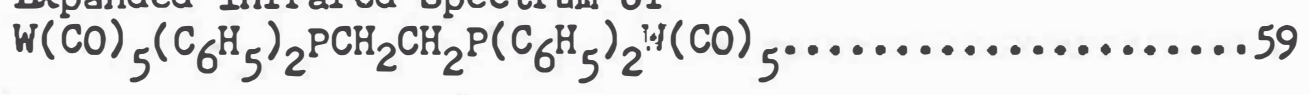

25. Expanded Infrared Spectrum of

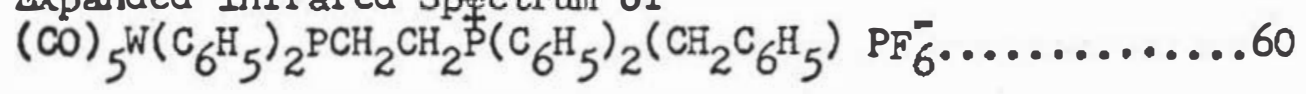

26. Expanded Infrared Spectrum of

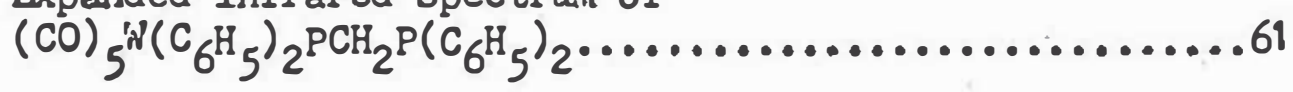

27. Expanded Infrared Spectrum of

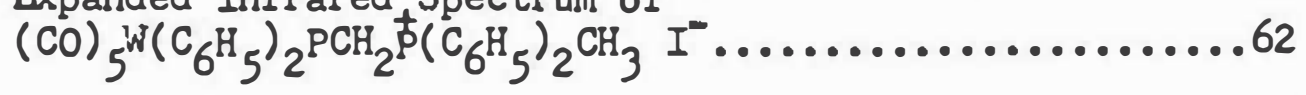

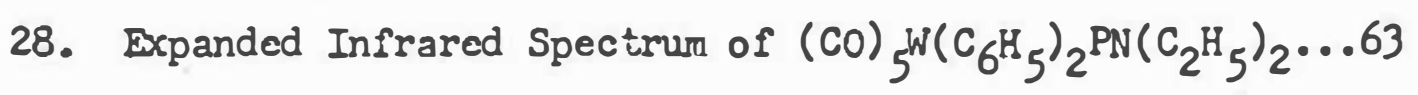

29. P-31 nmr Spectrum of $\left(\mathrm{CO}_{5}\right)_{5} \mathrm{IN}_{6}\left(\mathrm{C}_{6} \mathrm{H}_{5}\right)_{2} \mathrm{PCH}_{2}$ - of

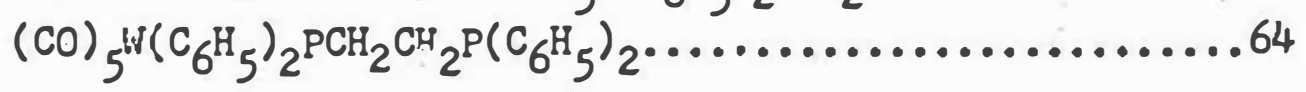

30. P-31 nor Spectrum of $\left(\mathrm{C}_{6} \mathrm{H}_{5} \mathrm{CH}_{2}\right)\left(\mathrm{C}_{6} \mathrm{H}_{5}\right)_{2} \mathrm{PCH}_{2}-$

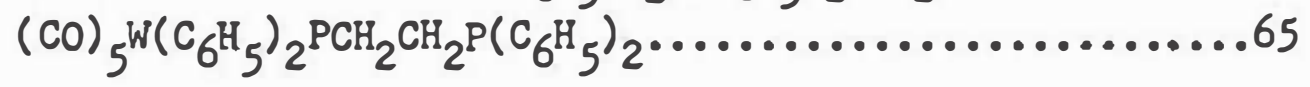


IIST OF TABLES

Table

Page

I Phosphorus-31 nor Data........................4

II Compilation of Positively Charged

Phosphorus Complexes...........................11

III Infrared Carbonyl Strotching Frequencies and Force Constants of Monosubstituted Pentacarbonyl

complexes...................................22 


\section{ABSTRACT}

Title of Thesis: Tungsten Carbonyl Complexes Containing

Positively Charged Phosphorus Ligands

Dilip P. Shah, Master of Science, 1971

Thesis directed by: Dr. Richard L. Keiter

Two positively charged complexes, $(\mathrm{CO})_{5} \mathrm{WP}\left(\mathrm{C}_{6} \mathrm{H}_{5}\right)_{2} \mathrm{CH}_{2} \mathrm{CH}_{2}-$ $\stackrel{+}{\mathrm{P}}\left(\mathrm{C}_{6} \mathrm{H}_{5}\right)_{2}\left(\mathrm{CH}_{2} \mathrm{C}_{6} \mathrm{H}_{5}\right) \quad \mathrm{Br}^{-}$and $(\mathrm{CO})_{5} \mathrm{~W}\left(\mathrm{C}_{6} \mathrm{H}_{5}\right)_{2} \mathrm{PCH}_{2}^{+}{ }^{+}\left(\mathrm{C}_{6} \mathrm{H}_{5}\right)_{2} \mathrm{CH}_{3} \mathrm{I}^{-}$ were synthesized, and their carbonyl stretching frequencies and force constants were compared to those of the uncharged complexes, ( $\mathrm{CO})_{5} \mathrm{NP}\left(\mathrm{C}_{6} \mathrm{H}_{5}\right)_{2} \mathrm{CH}_{2} \mathrm{CH}_{2} \mathrm{P}\left(\mathrm{C}_{6} \mathrm{H}_{5}\right)_{2}$ and $(\mathrm{CO})_{5} \mathrm{WP}\left(\mathrm{C}_{6} \mathrm{H}_{5}\right)_{2}-$ $\mathrm{CH}_{2} \mathrm{P}\left(\mathrm{C}_{6} \mathrm{H}_{5}\right)_{2}$. Within experimental error, no differences in infrared data were noted for $(\mathrm{CO})_{5} \mathrm{WP}\left(\mathrm{C}_{6} \mathrm{H}_{5}\right)_{2} \mathrm{CH}_{2} \mathrm{CH}_{2} \stackrel{+}{\mathrm{P}}\left(\mathrm{C}_{6} \mathrm{H}_{5}\right)_{2}^{-}$ $\left(\mathrm{CH}_{2} \mathrm{C}_{6} \mathrm{H}_{5}\right) \quad \mathrm{Br}-$ and $(\mathrm{CO})_{5} \mathrm{WP}\left(\mathrm{C}_{6} \mathrm{H}_{5}\right)_{2} \mathrm{CH}_{2} \mathrm{CH}_{2} \mathrm{P}\left(\mathrm{C}_{6} \mathrm{H}_{5}\right)_{2}$. The complex $(\mathrm{CO})_{5} \mathrm{WP}\left(\mathrm{C}_{6} \mathrm{H}_{5}\right)_{2} \mathrm{CH}_{2} \stackrel{+}{\mathrm{P}}\left(\mathrm{C}_{6} \mathrm{H}_{5}\right)_{2} \mathrm{Cr}_{3} \mathrm{I}^{-}$had a signiricantly larger $k_{1}$ force constant than did $(\mathrm{CO})_{5} \mathrm{WP}\left(\mathrm{C}_{6} \mathrm{H}_{5}\right)_{2} \mathrm{CH}_{2} \mathrm{P}\left(\mathrm{C}_{6} \mathrm{H}_{5}\right)_{2}$. This offect is interpreted as arising from the ability of the positive charge to withdraw electron density from the metal which reakens the metal-carbon bond and strengthens the $C 0$ bond.

A tungsten-phosphorus coupling constant of $270 \mathrm{~Hz}$ was recorded for $(\mathrm{CO})_{5} \mathrm{~W}\left(\mathrm{C}_{6} \mathrm{H}_{5}\right)_{2} \mathrm{PCH}_{2} \mathrm{CH}_{2} \mathrm{P}\left(\mathrm{C}_{6} \mathrm{H}_{5}\right)_{2}$ which suggests a metal-phosphorus bond of the same strength as the metal- 
phosphorus bond in $(\mathrm{CO})_{5} W P\left(\mathrm{C}_{6} \mathrm{H}_{5}\right)_{3}$. A phosphorus-phosphorus coupling value of $32.1 \mathrm{~Hz}$ was noted.

Synthetically, it was observed that $\mathrm{C}_{6} \mathrm{H}_{5} \mathrm{NH}_{2} \mathrm{~W}(\mathrm{CO})_{5}$ reacts with $\left(\mathrm{C}_{6} \mathrm{H}_{5}\right)_{2} \mathrm{PCH}_{2} \mathrm{CH}_{2} \mathrm{P}\left(\mathrm{C}_{6} \mathrm{H}_{5}\right)_{2}$ to give a mixture of $(\mathrm{CO})_{5}{ }^{\mathrm{IV}}\left(\mathrm{C}_{6} \mathrm{H}_{5}\right)_{2}$ $\mathrm{CH}_{2} \mathrm{CH}_{2} \mathrm{P}\left(\mathrm{C}_{6} \mathrm{H}_{5}\right)_{2}$ and $(\mathrm{CO})_{5} \mathrm{~W}\left(\mathrm{C}_{6} \mathrm{H}_{5}\right)_{2} \mathrm{PCH}_{2} \mathrm{CH}_{2} \mathrm{P}\left(\mathrm{C}_{6} \mathrm{H}_{5}\right)_{2}\left(\mathrm{~W}(\mathrm{CO})_{5}\right)$ with the formation of the latter being favored. The monometallic product can be obtained predominantly if a largd exsess of free Ingand is employed in the reaction. With $\left(\mathrm{C}_{6} \mathrm{H}_{5}\right)_{2} \mathrm{PCH}_{2} \mathrm{P}\left(\mathrm{C}_{6} \mathrm{H}_{5}\right)_{2}$. there is no tendency for the formation of the dimetallic complex nor does the monometallic complex $(\mathrm{CO})_{5} \mathrm{~W}\left(\mathrm{C}_{6} \mathrm{H}_{5}\right)_{2} \mathrm{CH}_{2} \mathrm{P}\left(\mathrm{C}_{6} \mathrm{H}_{5}\right)_{2}$ react with benzyl bromide. The inactivity of the dangling phosphorus is thought to be steric in nature because quaternization does occur with lodomethane. Attempts to prepare a complex such as (CO) $5^{\mathrm{WP}}\left(\mathrm{C}_{6} \mathrm{H}_{5}\right)_{2} \stackrel{+}{\mathrm{N}}\left(\mathrm{C}_{2} \mathrm{H}_{5}\right)_{3} \mathrm{BF}_{4}^{-}$with the positive charge in the position alpha to phosphorus were unsuccessful.

Infrared evidence is presented which suggests that the

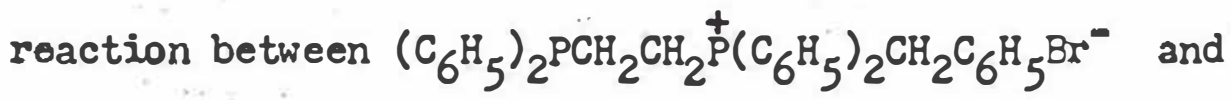
$\mathrm{C}_{6} \mathrm{H}_{5} \mathrm{NH}_{2} \mathrm{~W}(\mathrm{CO})_{5}$ in methanol yields predominantly $(\mathrm{CO})_{4} \mathrm{Br}^{-} \cdot \mathrm{WP}\left(\mathrm{C}_{6} \mathrm{H}_{5}\right)_{2} \mathrm{CH}_{2}^{-}$ $\mathrm{CH}_{2} \stackrel{+}{\mathrm{P}}\left(\mathrm{C}_{6} \mathrm{H}_{5}\right)_{2} \mathrm{CH}_{2} \mathrm{C}_{6} \mathrm{H}_{5}$ which represents a new class of compounds. 


\section{CHAPTER I}

\section{INTRODUCTION}

During the last twenty years, studies of the chemistry of phosphorus-contalning complexes have expanded enormously. This has been the result of several factors. It has been found that trivalent phosphorus ligands have the abllity to stabilize a number of very Interesting and usenil complexes. Many of these complexes are of commerclal importance as a result of their use in homogeneous catalysis.

Phosphorus ligands are more interesting than amine ligands from a bonding point of view. When the nitrosen of an amine ligand, $R_{3} N$, coordinates to a metal, there is a formation of a dative $\sigma$ bond, $M \leftarrow N R_{3}$, which is the result of the lone pair of $N$ (consisting of some $2 s$ and some $2 p$ character) being donated to avallable empty orbitals of the metal which have the approprlate symmetry. Any d orbitals of the metal which contaln potentially back donating electrons, cannot overlap with empty d orbitals of $N$, as there are none avallable of suitable energy. When the phosphorus of $R_{3} P$ is coordinated to a metal, the dative $\sigma$ bond is formed and the possibility of a dr-dir bond from metal to ligand exists. The d orbitals of the metal are of approprlate energy and symmetry for overlap to take place. 
Considerable discussion can be found in the literature regardIng the relative importance of $\pi$-bonding in the metal-phosphorus bond. Some, such as R. J. Angelici, are convinced that such bondine is minimal. 1 Others, such as S. O. Grim, are convinced that back donation has considerable influence in determining the nature of the phosphorus-metal bond. 2

The type of complexes discussed in this thesis are pseudooctahedral complexes of $\mathrm{C}_{4 \mathrm{~V}}$ syometry, where five carbonyl groups are bound to tungsten and the sixth group is a trivalent phosphorus ligand, $R_{3} P$.

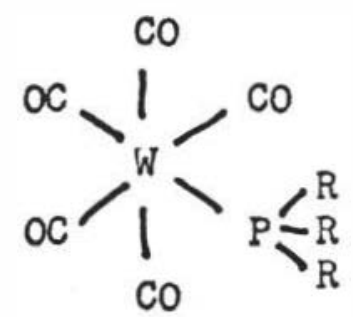

There are several methods by which one could get some measure of the strength of the phosphorus-metal bond. These include crystal structure, metal-phosphorus coupling constants, metal-phosphorus stretching frequencies and C.O stretching frequencies. For example, Stewart and Grim have done the structural study of two complexes, one containing a phosphite and one containing a phosphine.

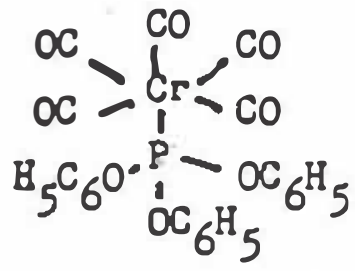<smiles>O=C([O-])C(C(=O)[O-])(C(=O)[O-])P(=O)(c1ccccc1)c1ccccc1</smiles> 
For the phosphite, the M-P bond distance is $2.309 \mathrm{~A}$, and for the phosphine it is $2.422 \mathrm{~A}$. These data suggest a stronger M-P bond in the phosphite complex. Grim has attributed this to the better $\Pi$ accepting ability of the phosphite complex. Others would argue that the more electronegative substituent on $P$ in the phosphite complex would enhance the s electron density in the $\mathrm{Cr}-\mathrm{P}$ bond, thereby drawing the two atoms closer together. ${ }^{3}$

A number of tungsten-phosphorus coupling constants have been determined. Rngsten-183, which is about 14,0 abundant has a nuclear spin of $\frac{1}{2}$ as does phosphorus-31. A typical P-31 spectrum excluding any phosphorus-hydrogen coupling would consist of an apparent 1:11.5:1 triplet as shown in Figure 1.

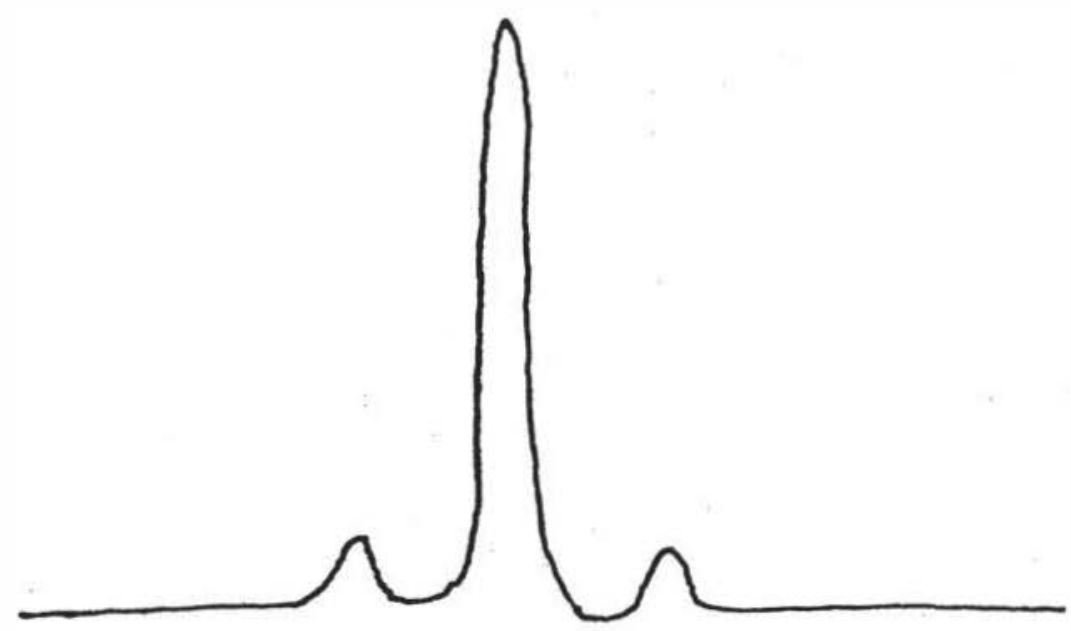

F1g. 1 A Iypical P-31 Spectrum of an $\operatorname{LW}(\mathrm{CO})_{5}$ Complex 
The suteifie peals arise fror the ${ }^{183.31} \mathrm{p}$ coupline while the center line is the result of those P-31 nuclei which are bonded to tungsten not possessing a nuclear spin of $\frac{1}{2}$. Studies have shown that the magnitudes of the coupling constants are quite related to the electron withdrawing ability of substituents on phosphorus. ${ }^{4}$ In Table I are found some representative complexes which show this trend.

Table I Phosphorus-31 NMR Data ${ }^{4}$

\begin{tabular}{|c|c|}
\hline Compound & ${ }^{J_{183}{ }_{N-}{ }^{31} \mathrm{P}}$ \\
\hline$\left(\mathrm{C}_{4} \mathrm{H}_{9}\right)_{3} \mathrm{Pid}(\mathrm{CO})_{5}$ & 200 \\
\hline$\left(\mathrm{C}_{4} \mathrm{H}_{9}\right)_{2} \mathrm{C}_{6} \mathrm{H}_{5} \mathrm{P}^{-1}(\mathrm{CO})_{5}$ & 235 \\
\hline$\left(\mathrm{C}_{4} \mathrm{H}_{9}\right)\left(\mathrm{C}_{6} \mathrm{H}_{5}\right)_{2} \mathrm{PW}(\mathrm{CO})_{5}$ & 250 \\
\hline$\left(\mathrm{C}_{6} \mathrm{H}_{5}\right)_{3} \operatorname{Piv}(\mathrm{CO})_{5}$ & 270 \\
\hline $\mathrm{C}_{5} \mathrm{H}_{11} \mathrm{C}\left(\mathrm{CH}_{2} \mathrm{~N}\left(\mathrm{CH}_{3}\right)\right)_{3} \mathrm{PH}(\mathrm{CO})_{5}$ & 318 \\
\hline $\mathrm{C}_{5} \mathrm{H}_{11} \mathrm{C}\left(\mathrm{CH}_{2} \mathrm{O}\right)_{3} \mathrm{P}^{\prime} N(\mathrm{CO})_{5}$ & 393 \\
\hline $\mathrm{F}_{3} \operatorname{PiN}(\mathrm{CO})_{5}$ & 485 \\
\hline
\end{tabular}

In these complexes the same two bonding arguments are applicable. However, it appears that the $d \pi-d \pi$ argument is a less cogent explanation of these data. This results primarily from the theoretical description of coupling constants. It is felt that nuclei can only couple via s electron density, and that other coupling mechanisms, such as dipole-dipole interactions, contribute very little to coupling 
magnitude. If the theoretical equations are correct, it is unlikely that the diffuse d orbitals contribute to the magnitude of coupling constants. Regardless of the bonding arguments used, it does appear that as the electronegativity of substituents on phosphorus increases. a stronger metal-phosphorus bond is created.

A third and more indirect approach to the metal phosphorus bond strength comes from the evaluation of the C-O force constants. It is well accepted that $C O$ is a very good $\pi$ mbonding ligand as a result of its ability to accept electron density into its antibonding 2 p orbitals.

When a phosphorus ligand replaces a $\mathrm{CO}$ group of $\mathrm{ir}_{(\mathrm{CO})} 6$, the charge on the metal increases considerably. The excess charge finds its way into the d orbitals of the metal, which increases the electron density in the antibonding orbitals of $\mathrm{CO}$ and this In turn weakens the C-O bond. Therefore, one observes the C-O stretching frequency falling to a lower value. One may also compare the $\pi$-bonding strength of $\mathrm{CO}$ with $\mathrm{R}_{3} \mathrm{P}$, and in doing $\mathrm{sq}$, the $\mathrm{CO}$ group is found to be much superior. Therefore, $\mathrm{CO}$ should be more successful than $R_{3} P$ at withdrawing 7 electron density from the metal. It must be added that the observed co stretching frequency lowering can also be rationalized by assuming that the $\pi$ bonding ability of $R_{3} P$ is insignificant. $R_{3} N$ groups put even more charge on the metal than do RyP groups, and as expected, replacing a $C O$ group with $R_{3} N$ lowers $C 0$ stretching frequencies even more than $R_{3} P$ groups. 
The number of $\mathrm{CO}$ bands that are observed in a monosubstituted tungsten hexacarbonyl under ideal conditions is 3 . As can be shown from group theory calculations, three infrared bands should be found for complexes of $C_{4 V}$ symmetry. Flgure 2 shows a typical infrared spectrun for complexes of this type. The C-O stretching frequency is invariably found in the region from 1900 to $2100 \mathrm{~cm}^{-1}$.

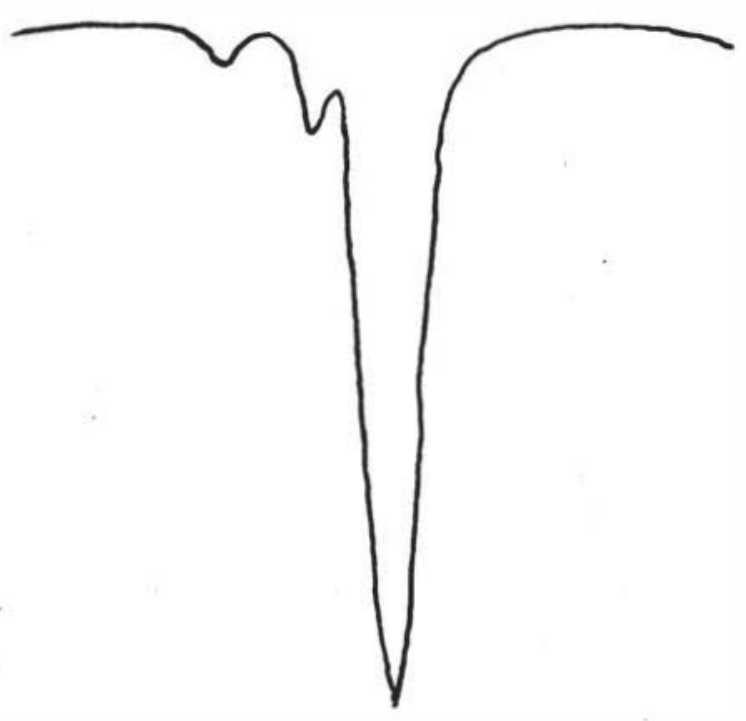

F1g. 2 C-O Stretching Region of the Infrared Spectrum of a Lix(CO) $\mathrm{g}$ Conplex 
The ${ }_{9}^{2} \mathrm{~A}$ mode is the result of equatorial and axial interaction, while $E$ corresponds to equatorial $C O$ groups and ${ }_{\mathfrak{q}} A$ to the $C O$ group trans to L. The stretching frequencies are not nearly as indicative of the strength of the $\mathrm{CO}$ bond as are force constants.

From the three stretching frequencies, three force constants can be calculated. F. Cotton has used an approximate force field to derive secular equations that enable approximate force constants to be found. 5 The secular equations used for $C_{4 V}$ symmetry are

$$
\left|\begin{array}{ll}
\mu k_{1}-\lambda & 2 \mu k_{1} \\
2 \mu k_{1} & \mu\left(k_{2}+4 k_{i}\right)-\lambda
\end{array}\right|=0 \text { and } \lambda=\mu\left(k_{2}-2 k_{i}\right)
$$

where $\mu=$ reciprocal of reduced mass for $C O=\frac{16.0+12.01}{16.0 \times 12.01}=0.1458$ and $\lambda=\left(5.8890 \times 10^{-2}\right) \nu^{2}$ with $\nu$ expressed in $\mathrm{cm}^{-1}$. The force constants are expressed in mdynes $\mathrm{cm}^{-1}$.

The algebraic solution to the equations and the computer program for obtaining values are found in Appendix $I$.

Compared with extensive numbers of investigations of transition metal complexes of neutral and anionic ligands, relatively few studies with positively charged ligands have been reported. The purpose of this research has been to prepare positively charged phosphorus ligands, coordinate them to tungsten, measure carbonyl stretching frequencies, obtain tungsten-phosphorus coupling constants and compare these positively charged ligands to neutral ligands. As has been pointed out, the metal-phosphorus bond becomes stronger as more electronegative groups are attached to phosphorus. 
It would seem reasonable that as a positive charge is moved closer and closer to the coordinated phosphorus atom, electron density would be drawn toward the positive charge to a greater and greater extent. In fact, a positive charge in the alpha position to phosphorus would probably create an effect similar to the excellent electron withdrawing group F. As of this work, no systematic attempts had been made to evaluate the characteristics of complexes of positively charged ligands.

The complexes chosen to be made for the study were:

$$
\begin{aligned}
& \mathrm{Br}^{-} \mathrm{Ph}_{3} \stackrel{+}{\mathrm{PCH}_{2} \mathrm{CH}_{2} \mathrm{PPh}_{2} \mathrm{~W}(\mathrm{CO})_{5}} \\
& \mathrm{Br}^{-} \mathrm{Ph}_{3}{ }_{3}^{+} \mathrm{PCH}_{2} \mathrm{PPh}_{2} \mathrm{~W}(\mathrm{CO})_{5} \\
& \mathrm{Br}^{-} \mathrm{Ph}_{3} \stackrel{+}{+} \mathrm{PPh}_{2} \mathrm{~W}(\mathrm{CO})_{5} \\
& \mathrm{Br}^{-} \mathrm{Et}_{3} \stackrel{+}{\mathrm{IPPP}} \mathrm{IP}_{2} \mathrm{~W}(\mathrm{CO})_{5}
\end{aligned}
$$

None of these complexes was known and for some of them, as will be described in the discussion, synthesis was not an easy task.

There are a few examples of complexes of positively charged complexes in the literature. Bergland and Neek ${ }^{6}$ prepared a positively charged phos phorus ligand,

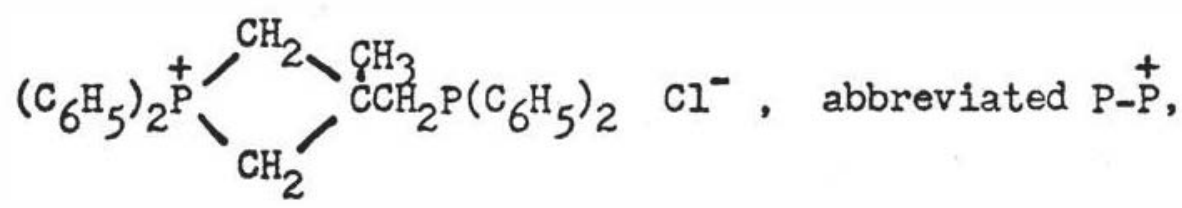

which was coordinated to form $M_{-}\left(P_{-} \stackrel{+}{P}\right) X_{3}$ where $M=C_{0}, N i, P d$, Cu and $\mathrm{X}=\mathrm{Cl}, \mathrm{Br}, \mathrm{I}$. These complexes are quite stable, have pseudototrahedral structure, and the coordination tendency of the 
diphenyl phosphino group was not affected by the presence of the quaternary phosphorus atom. Studies of this ligand were continued by Bergland and Yeek ${ }^{9}$ but no additional significant information was obtained.

Bertrand, et $a l^{?}$, were successful in preparing a complex of the same general class as those in this thesis. The lizand $\mathrm{P}\left(\mathrm{OCH}_{2}\right)_{3} \mathrm{P}$ was coordinated and quaternized to form $(\mathrm{CO})_{5} \mathrm{WP}\left(\mathrm{OCH}_{2}\right)_{3}$ $\stackrel{+}{\mathrm{PCH}}_{3} \mathrm{Br}_{4}{ }^{-}$. They detected no noticeable effect of the charge on the metal-phosphorus bond. It should be pointed out, however, that in the study done by Bertrand and also in the one by Bergland the positive charge was never very close to the metal-phosphorus bond and hence little effect would be expected.

The only other studies of positively charged phosphorus ligands were done by Quagliano and coworkers ${ }^{8}$. They studied the donor properties of positively charged pseudotetrahedral $\mathrm{Co}_{\text {(II) and } \mathrm{N}}$ (II) complexes containing monoquaternized ditertiary phosphines, $\mathrm{MX}_{2}-$ $\left(\mathrm{Ph}_{2} \mathrm{PCH}_{2} \mathrm{CH}_{2} \stackrel{+}{\mathrm{PPh}}\right) \mathrm{X}$ and $\mathrm{HX}_{2}\left(\mathrm{Ph}_{2} \mathrm{PCH}_{2} \stackrel{+}{\mathrm{PPh}}{ }_{3}\right) \mathrm{X}$, where $\mathrm{N}=\mathrm{Co}, \mathrm{N} 1$ and $\mathrm{X}=\mathrm{Cl}$, $\mathrm{Br}$. I. The authors concluded that the presence of a positive charge on the phosphine cationic ligand, although it undoubtedly contributes to the stability of the complexes and favors their formation by providing the suitable 1:3 metal to halide ratio, has very little Influence on the ligating character of the phosphorus donor atom. The complexes with which they worked were very insoluble. For this reason, except for solld state uv, they had no experimental 
method to determine effects of the positive charge. Table II contains a compilation of positively charged phosphorus complexes. 
Table II. Compllation of Complexes Contalning LIgands of Positively Charged Phosphorus

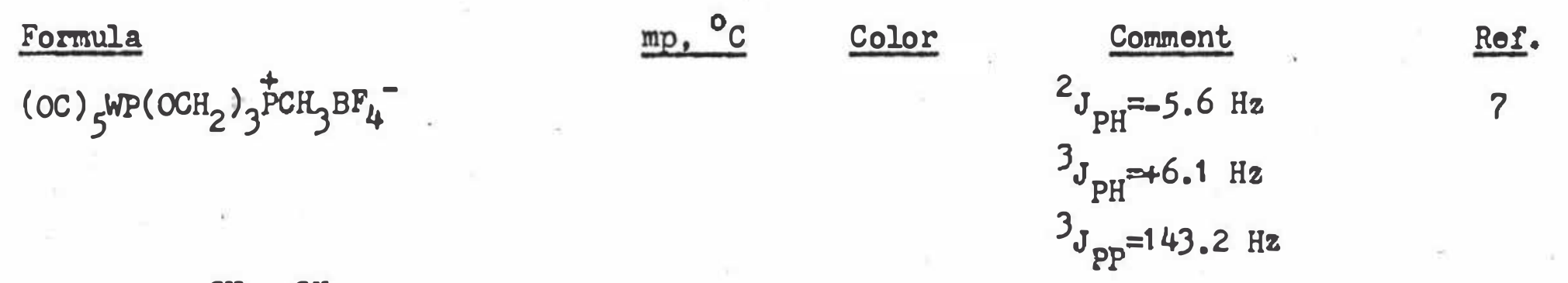<smiles>[H][R](c1ccccc1)C1(C)CC[P+](c2ccccc2)C1</smiles>

(Abbroviated $\stackrel{+}{\mathrm{P}}-\mathrm{P}$ )

$$
\begin{aligned}
& \mathrm{N} 1(\stackrel{+}{\mathrm{P}}-\mathrm{P}) \mathrm{Cl}_{3} \\
& \mathrm{~N} 1(\stackrel{+}{\mathrm{P}}-\mathrm{P}) \mathrm{BrCl}_{2} \\
& \mathrm{~N} 1(\stackrel{+}{\mathrm{P}}-\mathrm{P}) \mathrm{Br}_{2} \mathrm{Cl} \\
& \mathrm{Co}(\stackrel{+}{\mathrm{P}}-\mathrm{P}) \mathrm{Cl}_{3} \\
& \mathrm{Co}(\stackrel{+}{\mathrm{P}}-\mathrm{P}) \mathrm{I}_{3} \\
& \mathrm{Pd}(\stackrel{+}{\mathrm{P}}-\mathrm{P}) \mathrm{Cl}_{3} \\
& \mathrm{Pd}(\stackrel{+}{\mathrm{P}}-\mathrm{P}) \mathrm{Cl}_{2}\left(\mathrm{ClO}_{4}\right)_{2} \\
& \mathrm{Au}(\stackrel{+}{\mathrm{P}}-\mathrm{P}) \mathrm{Cl}_{3}
\end{aligned}
$$

\section{Wh1to crystals}

Roported magnot1o susceptibllities. conductivities. visible and UV studies.

Blue

Turquolso

Blutsh

Blue

Blu1sh

green

Orange

Orange

Orange 
Toble II. Continued

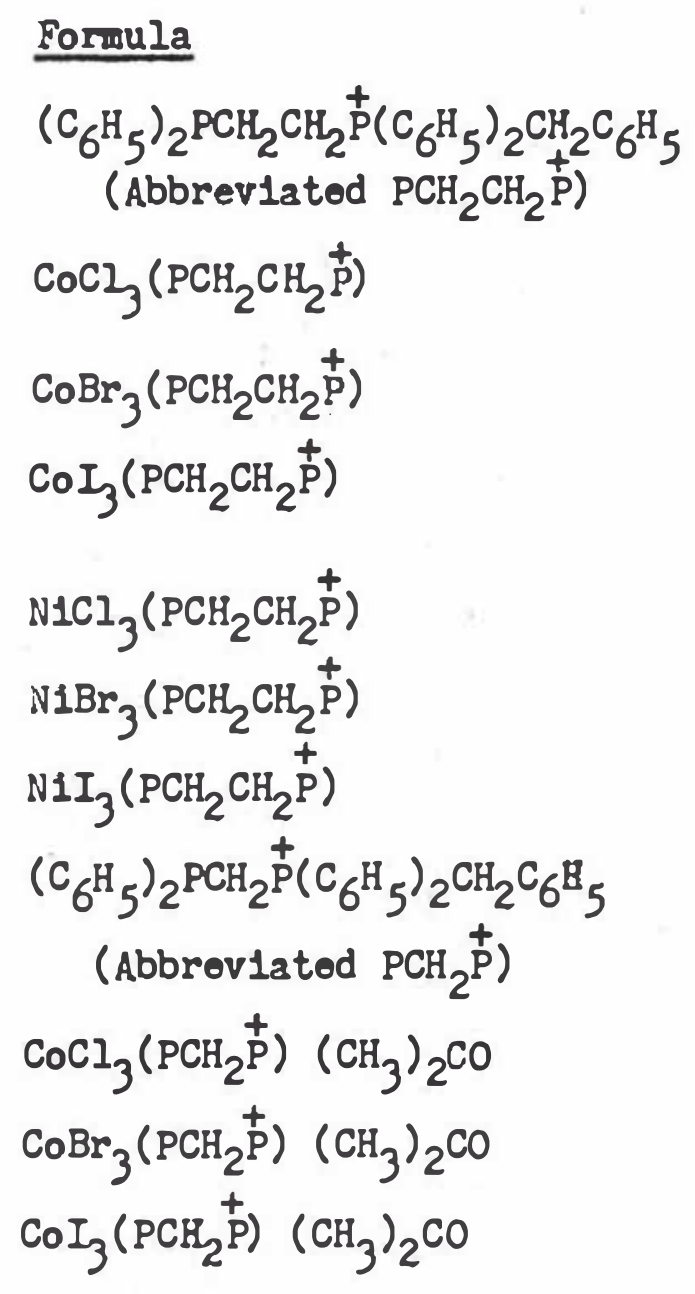

\begin{tabular}{|c|c|c|c|}
\hline $\mathrm{mp},{ }^{\circ} \mathrm{C}$ & Color & Comvent & Rer \\
\hline & & $\begin{array}{l}\text { UV and IR study } \\
\text { In solld state }\end{array}$ & 8 \\
\hline & Blue & & 8 \\
\hline & Blue & & 8 \\
\hline & $\begin{array}{l}\text { Yollow } \\
\text { green }\end{array}$ & & 8 \\
\hline & Blue & & 8 \\
\hline doo 280 & Turquo1so & & 8 \\
\hline & Dark brown & & 8 \\
\hline & & $\begin{array}{l}\text { UV and IR study } \\
\text { In solld state }\end{array}$ & 8 \\
\hline & Blue & & 8 \\
\hline & Blue & & 8 \\
\hline & $\begin{array}{l}\text { Chartrouso } \\
\text { blue }\end{array}$ & & 8 \\
\hline
\end{tabular}

Rof. 
Table II. Continued

Foroula

$\mathrm{NiCl}_{3}\left(\mathrm{PCH}_{2} \stackrel{+}{\mathrm{P}}\right)\left(\mathrm{CH}_{3}\right)_{2} \mathrm{CO}$

$\mathrm{NiBr}_{3}\left(\mathrm{PCH}_{2} \stackrel{+}{\mathrm{P}}\right)\left(\mathrm{CH}_{3}\right)_{2} \mathrm{CO}$

$\mathrm{NiI}_{3}\left(\mathrm{PCH}_{2} \stackrel{+}{\mathrm{P}}\right)\left(\mathrm{CH}_{3}\right)_{2} \mathrm{CO}$ $\mathrm{mp}_{1}{ }^{\circ} \mathrm{C}$

Color

areenish

blue

Green

Brown
Coument

Rer. 
CHAPTER II

\section{RESULTS AND DISCUSSION}

\section{A. Synthetic Aspects}

The details of all syntheses described in this section are found in the experimental section.

In the preparation of the positively charged complex. $\left(\mathrm{C}_{6} \mathrm{H}_{5}\right)_{2}\left(\mathrm{CH}_{2} \mathrm{C}_{6} \mathrm{H}_{5}\right) \stackrel{+}{\mathrm{P}}\left(\mathrm{CH}_{2}\right)_{x} P\left(\mathrm{C}_{6} \mathrm{H}_{5}\right)_{2} \mathrm{PS}(\mathrm{CO})_{5} \mathrm{Br}-(\mathrm{x}=1,2)$, the first approach was to prepare the neutral ligand. $\left(\mathrm{C}_{6} \mathrm{H}_{5}\right)_{2} \mathrm{P}\left(\mathrm{CH}_{2}\right)_{x} \mathrm{P}\left(\mathrm{C}_{6} \mathrm{H}_{5}\right)_{2}(x=1,2)$. quaternize one end of it and coordinate the other end by utilizing a displacement reaction. The neutral ligands wero prepared by a standard procedure which involved the following reactions:

1) $\mathrm{LI}+\mathrm{P}\left(\mathrm{C}_{6} \mathrm{H}_{5}\right)_{3} \longrightarrow \mathrm{C}_{6} \mathrm{H}_{5} \mathrm{II}+\mathrm{LIP}\left(\mathrm{C}_{6} \mathrm{H}_{5}\right)_{2}$

2) $\mathrm{C}_{6} \mathrm{H}_{5} \mathrm{Ii}+\left(\mathrm{CH}_{3}\right)_{3} \mathrm{CCl} \longrightarrow \mathrm{C}_{6} \mathrm{H}_{6}+\mathrm{IiCl}+\left(\mathrm{CH}_{3}\right)_{2} \mathrm{CH}_{2}=\mathrm{CH}_{2}$

3) $\operatorname{LiP}\left(\mathrm{C}_{6} \mathrm{H}_{5}\right)_{2}+\mathrm{CI}\left(\mathrm{CH}_{2}\right)_{x} \mathrm{Cl} \longrightarrow\left(\mathrm{C}_{6} \mathrm{H}_{5}\right)_{2} \mathrm{P}\left(\mathrm{CH}_{2}\right)_{x} \mathrm{P}\left(\mathrm{C}_{6}{ }_{5}\right)_{2}$

The nme spectrum of $\left(\mathrm{C}_{6} \mathrm{H}_{5}\right)_{2} \mathrm{PCH}_{2} \mathrm{CH}_{2} \mathrm{P}\left(\mathrm{C}_{6} \mathrm{H}_{5}\right)_{2}$ is shown in Figure 3. Excluding phenyl protons, the compound represents an $X \mathbb{Q}_{2} A_{2}^{\prime} X^{\prime}$ type. The apparent triplet is the result of strong hydrogen-hydrogen coupling which makes the spectrum second order. The nor spectram (Figure 4) of $\left(\mathrm{C}_{6} \mathrm{H}_{6}\right)_{2} \mathrm{PCH}_{2} \mathrm{P}\left(\mathrm{C}_{6} \mathrm{H}_{5}\right)_{2}$ is an $\mathrm{A}_{2} \mathrm{X}_{2}$ type with very small phosphorus-hydrogen coupling of $1.6 \mathrm{~Hz}$.

Followlng the procedure of Quagliano ${ }^{8}$. one end of $\left(\mathrm{C}_{6} \mathrm{H}_{5}\right)_{2}^{-}$ 
$\mathrm{PC} \mathrm{H}_{2} \mathrm{P}\left(\mathrm{C}_{6} \mathrm{H}_{5}\right)_{2}$ and ô $\left(\mathrm{C}_{6} \mathrm{H}_{5}\right)_{2} \mathrm{PCH}_{2} \mathrm{CH}_{2} \mathrm{P}\left(\mathrm{C}_{6} \mathrm{H}_{5}\right)_{2}$ were quaternized with $\mathrm{BrCH}_{2} \mathrm{C}_{6} \mathrm{H}_{5}$ to form $\left(\mathrm{C}_{6} \mathrm{H}_{5}\right)_{2} \mathrm{PCH}_{2}^{+}{ }^{+}\left(\mathrm{C}_{6} \mathrm{H}_{5}\right)_{2}\left(\mathrm{CH}_{2} \mathrm{C}_{6} \mathrm{H}_{5}\right) \mathrm{Br}^{-}$and $\left(\mathrm{C}_{6} \mathrm{H}_{5}\right)_{2}$. P$\mathrm{CH}_{2} \mathrm{CH}_{2} \stackrel{+}{\mathrm{P}}\left(\mathrm{C}_{6} \mathrm{H}_{5}\right)_{2}\left(\mathrm{CH}_{2} \mathrm{C}_{6} \mathrm{H}_{5}\right) \mathrm{Br}^{-}$.

Thermally, tungstenhexacarbonyl undergoes a Lewis base reaction with nucleophilic ligands (:B) to give cis and trans disubstituted and monosubstituted products.

$$
W(C O)_{6}+: B \frac{130^{\circ}}{\begin{array}{c}
\text { diglyme } \\
\text { polyether) }
\end{array}} \text { cis- and trans. } W(C O)_{4} B_{2}+W(C O)_{5} B
$$

A similar type of reaction occurs when tungstenbexacarbonyl is irradiated with ultraviolet light.

$W(\mathrm{CO})_{6}+: B \frac{\text { av }}{\text { THF(dry) }}$ cis- and trans-W( $(\mathrm{CO})_{4} B_{2}+W(\mathrm{CO})_{5} B$

It is possible to use column chromatography to separate monosubstituted complexes from disubstituted ones, but this procedure is time-consuming and yields are low. In addition. a chelating ligand such as $\left(\mathrm{C}_{6} \mathrm{H}_{5}\right)_{2} \mathrm{PCH}_{2} \mathrm{CH}_{2} \mathrm{P}\left(\mathrm{C}_{6} \mathrm{H}_{5}\right)_{2}$ has a great tendency to form cis products exclusively if conditions as drastic as those above are employed.

Recently it was shown by Keiter and Verkade ${ }^{4}$ that an excellent synthetic approach to monosubstituted tungstenhexacarbonyl complexes involves the displacement of $\mathrm{C}_{6} \mathrm{H}_{5} \mathrm{NR}_{2}$ in $\mathrm{C}_{6} \mathrm{H}_{5} \mathrm{NH}_{2} \mathrm{~W}(\mathrm{CO})_{5}$. It was assumed that such a synthesis would be applicable in this work. The aniline complex was prepared from the reaction of $w(C O)_{6}$ 
and aniline by irradiating the reaction mixture with uv light. Aruines such as aniline, which put considerable charge on the metal, never form disubstituted products. The following reaction was attempted in methanol.

$$
\begin{aligned}
& \mathrm{C}_{6} \mathrm{H}_{5} \mathrm{NH}_{2} \mathrm{~W}(\mathrm{CO})_{5}+\left(\mathrm{C}_{6} \mathrm{H}_{5}\right)_{2} \mathrm{P}\left(\mathrm{CH}_{2}\right)_{x} \stackrel{+}{\mathrm{P}\left(\mathrm{C}_{6} \mathrm{H}_{5}\right)_{2}\left(\mathrm{CH}_{2} \mathrm{C}_{6} \mathrm{H}_{5}\right)} \mathrm{Br}^{-} \longrightarrow \\
& \mathrm{C}_{6} \mathrm{H}_{5} \mathrm{NH}_{2}+\mathrm{W}(\mathrm{CO})_{5}\left(\mathrm{C}_{6} \mathrm{H}_{5}\right)_{2} \stackrel{+}{\mathrm{P}}\left(\mathrm{CH}_{2}\right)_{x} \mathrm{P}^{\mathrm{P}\left(\mathrm{C}_{6} \mathrm{H}_{5}\right)_{2}\left(\mathrm{CH}_{2} \mathrm{C}_{6}{ }_{5}\right)} \mathrm{Br}-
\end{aligned}
$$

Methanol was used because the positively charged ligand was sparingly soluble in nonpolar solvents.

It was surprising to find that the reaction was not straightforward. The compound recovered from the reaction mixture was clearly not a complex of the type $\mathrm{IW}(\mathrm{CO})_{5}$ ( $\mathrm{I}=$ ligand). This was confirmed by its infrared spectrum (Figure 5). The spectrum was taken as a nujol mull, because the compound was insoluble in chloroform. The spectrum consisted of five bands, the most significant of which are those at 1903 and $1834 \mathrm{~cm}^{-1}$. These bands are much too low in frequency for a monosubstituted complex but fit nicely for a cis substituted complex of the type $\mathrm{L}_{2} \mathrm{~W}(\mathrm{CO})_{4}$. A complex of this type, which is of $\mathrm{C}_{2 V}$ symmetry, is expected to have four infrared active bands. The band at $1982 \mathrm{~cm}^{-1}$ may be due to $\mathrm{W}(\mathrm{CO})_{6}$ impurity. The insolubility of the complex prevented the application of the usual purification techniques, and the compound was, therefore, not analyzed. The infrared spectrum strongly suggests that the following reaction took place.

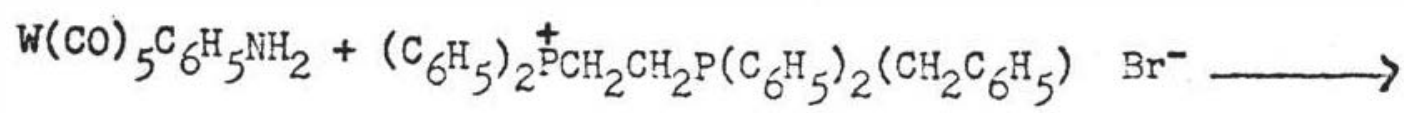


$\mathrm{CO}+(\mathrm{CO})_{4} \mathrm{BrW}^{-}\left(\mathrm{C}_{6} \mathrm{H}_{5}\right)_{2} \mathrm{PCH}_{2} \mathrm{CH}_{2} \stackrel{+}{\mathrm{P}}\left(\mathrm{C}_{6} \mathrm{H}_{5}\right)_{2} \mathrm{CH}_{2} \mathrm{C}_{6} \mathrm{H}_{5}+\mathrm{C}_{6} \mathrm{H}_{5} \mathrm{NH}_{2}$

The reaction was repeated several times and the same product appeared each time. Furthermore, $\left(\mathrm{C}_{6} \mathrm{H}_{5}\right)_{2} \mathrm{PCH}_{2} \stackrel{+}{\mathrm{P}}\left(\mathrm{CH}_{2} \mathrm{C}_{6} \mathrm{H}_{5}\right)_{2} \mathrm{Br}^{-}$ reacted in a similar manner, and the infrared spectrum of the product of this reaction is shown in Figure 6 . The band at 1834 $\mathrm{cm}^{-1}$ is noticeably missing. A search of the literature revealed no zwitterionic complex of this nature, although it was found

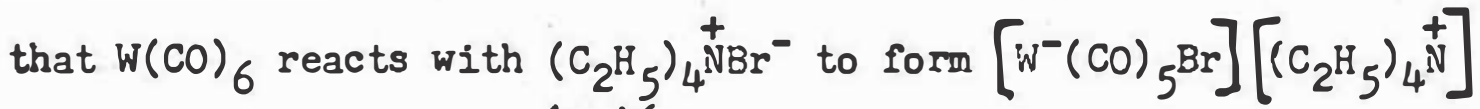
with the evolution of $\mathrm{CO}^{15,16}$ As the halide in this reaction behaves as a Lewis base, it may do likewise as part of tine positively charged ligand. Further work needs to be done with this reaction, but since it did not represent the basic purpose of this research, it was not explored further.

The next approach which was used to prepare a positively charged complex involved coordinating the neutral ligand by displacing aniline and then quaternizing the dangling end. $w(C O){ }_{5} C_{6}{ }_{5} \mathrm{NH}_{2}+\left(\mathrm{C}_{6} \mathrm{H}_{5}\right)_{2} \mathrm{P}\left(\mathrm{CH}_{2}\right)_{2} \mathrm{P}\left(\mathrm{C}_{6} \mathrm{H}_{5}\right)_{2} \longrightarrow$ $\mathrm{W}(\mathrm{CO})_{5}\left(\mathrm{C}_{6} \mathrm{H}_{5}\right)_{2} \mathrm{P}\left(\mathrm{CH}_{2}\right)_{2} \mathrm{P}\left(\mathrm{C}_{6} \mathrm{H}_{5}\right)_{2}+\mathrm{C}_{6} \mathrm{H}_{5} \mathrm{NH}_{2}$

It was found that when the aniline complex and the neutral ligand were allowed to react in a mole ratio of $1: 1$ that the predominant product was $(\mathrm{CO})_{5} \mathrm{~W}\left(\mathrm{C}_{6} \mathrm{H}_{5}\right)_{2} \mathrm{CH}_{2} \mathrm{CH}_{2} \mathrm{P}\left(\mathrm{C}_{6} \mathrm{H}_{5}\right)_{2} \mathrm{~W}(\mathrm{CO})_{5}$. The nor spectrum, Figure 7, reveals immeasurable small phosphorus-hydrogen coupling at $2.3 \mathrm{ppm}$. An expanded spectrum did not reveal any 
splitting. The molecular wolght of the compound was confirmed by mass spectral analysis.

Isolated as a minor product was the desired complex, $(\mathrm{CO})_{5} \mathrm{~W}\left(\mathrm{C}_{6} \mathrm{H}_{5}\right)_{2} \mathrm{PCH}_{2} \mathrm{CH}_{2} \mathrm{P}\left(\mathrm{C}_{6} \mathrm{H}_{5}\right)_{2}$, the structure of which was proven by P-31 nmr. This compound will be discussed in section $B$. When the ratio of aniline complex to free ligand was increased to $3: 1$, the desired complex was found in good yield. The mir spectrum (Figure 8) of the $\mathrm{XA}_{2} \mathrm{~B}_{2} \mathrm{M}$ type conplex was quite complicated in the methylene region. This complex reacted with $9 \mathrm{rCH}_{2} \mathrm{C}_{6} \mathrm{H}_{5}$ to give the desired positively charged complex, $(\mathrm{CO})_{5} \mathrm{~W}\left(\mathrm{C}_{6} \mathrm{H}_{5}\right)_{2} \mathrm{PaH}_{2} \mathrm{CH}_{2} \stackrel{+}{\mathrm{P}}-$ $\left(\mathrm{CH}_{2} \mathrm{C}_{6} \mathrm{H}_{5}\right)\left(\mathrm{C}_{6} \mathrm{H}_{5}\right)_{2} \mathrm{Br}^{-}$. The essentially second order spectrum (Figure 9) shows the benzyl proton coupled to phosphorus $\left(\mathrm{J}_{\mathrm{P}_{-} \mathrm{CH}_{2}}=\right.$ $15.5 \mathrm{~Hz}$ ). No further coupling can be observed in the expanded spectrum of the mothylene region (Figure 10). The analysis of the complex was somewhat low (see experimental section) which is due to the hygroscopic nature of the phosphonium salt. The complex was converted to the hexafluorophosphate salt. $(\mathrm{CO})_{5} \mathrm{~W}\left(\mathrm{C}_{6} \mathrm{H}_{5}\right)_{2} \mathrm{PCH}_{2} \mathrm{CH}_{2}^{+} \mathrm{P}\left(\mathrm{C}_{6} \mathrm{H}_{5}\right)_{2}\left(\mathrm{CH}_{2} \mathrm{C}_{6} \mathrm{H}_{5}\right) \mathrm{Br}^{-}+\mathrm{NH}_{4} \mathrm{PF}_{6} \longrightarrow$ $\left.\mathrm{NH}_{4} \mathrm{Br}+(\mathrm{CO})_{5} \mathrm{~W}_{\left(\mathrm{C}_{6}\right.} \mathrm{H}_{5}\right)_{2} \mathrm{PCH}_{2} \mathrm{CH}_{2} \stackrel{+}{\mathrm{P}}\left(\mathrm{C}_{6} \mathrm{H}_{5}\right)_{2}\left(\mathrm{CH}_{2} \mathrm{C}_{6} \mathrm{H}_{5}\right) \quad \mathrm{PF}_{6}^{-}$ This compound is not hygroscopic and a good analysis was obtained. Figure 11 sho:ss its $\mathrm{mmr}$ spectrum. The $\mathrm{P}-\mathrm{CH}_{2}$ coupling remains 15.5 Hz but has been shifted upfield as the result of a solvent effect. Acetone was used as the solvent for solubility reasons. When $\left(\mathrm{C}_{6} \mathrm{H}_{5}\right)_{2} \mathrm{PCH}_{2} \mathrm{P}\left(\mathrm{C}_{6} \mathrm{H}_{5}\right)_{2}$ was treated with the aniline complex, 
only a complex with one end coordinated, $\left(\mathrm{CO}_{5} \mathrm{~W}_{5}\left(\mathrm{C}_{6} \mathrm{H}_{5}\right)_{2} \mathrm{PCH}_{2} \mathrm{P}\left(\mathrm{C}_{6} \mathrm{H}_{5}\right)_{2}\right.$. could be isolated regardless of the ratio of reactants. Apparently. when one end becomes coordinated, the other end is surficiently deactivated to prevent further reaction. The nmr spectrum (Figure 12), an XA2M type, consists of a doublet of doublets in which phosphorus-hydrogen coupling is $\mathrm{J}_{\mathrm{W}-\mathrm{P}-\mathrm{CH}_{2}}=8.6 \mathrm{~Hz}$ and $\mathrm{J}_{\mathrm{P}_{-} \mathrm{CH}_{2}}=2.4 \mathrm{~Hz}$. The inactivity of the dangling end created a problem in quaternizing that end. No reaction occurred with $\mathrm{BrCH}_{2} \mathrm{C}_{6} \mathrm{H}_{5}$, and no product was isolated with the good alkylating agent, $8 t_{3} \mathrm{O}^{+} \mathrm{BF}_{4}^{-}$.

In one reaction, the aniline complex, benzylbromide, and the neutral ligand were mixed together in benzene and stirred for a few hours. Precipitation slowly occurred. This solid was washed with water to remove any $\mathrm{C}_{6} \mathrm{H}_{5} \mathrm{NH}_{2} \mathrm{CH}_{2} \mathrm{C}_{6} \mathrm{H}_{5} \quad \mathrm{Br}^{-}$and washed with benzene to remove any $\left(\mathrm{CO}_{5} \mathrm{~W}^{\mathrm{W}}\left(\mathrm{C}_{6} \mathrm{H}_{5}\right)_{2} \mathrm{PCH}_{2} \mathrm{P}\left(\mathrm{C}_{6} \mathrm{H}_{5}\right)_{2}\right.$. The $\mathrm{nmr}$ spectrum (Figure 13) showed that the compound was $\left(\mathrm{C}_{6} \mathrm{H}_{5}\right)_{2} \mathrm{PCH}_{2} \stackrel{+}{\mathrm{P}}-$ $\left(\mathrm{C}_{6} \mathrm{H}_{5}\right)_{2} \mathrm{CH}_{2} \mathrm{C}_{6} \mathrm{H}_{5} \mathrm{Br}^{-}$. This was established by synthesizing the compound from stoichiometric quantities of benzyl bromide and the free ligand. This reaction took place rapidly. On the basis of the benzyl chemical shift when this group is attached to a quaternized phosphorus atom (see Figure 9), the doublet at low field was attributed to phosphorus-hydrogen coupling (15.5 $\mathrm{Hz}$ ) and the trivalent phosphorus-hydrogen coupling was too small to be measured.

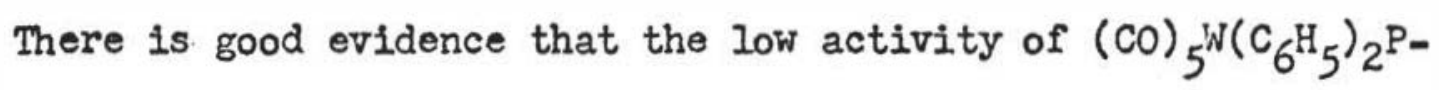


$\mathrm{CH}_{2} \mathrm{P}\left(\mathrm{C}_{6} \mathrm{H}_{5}\right)_{2}$ toward quaternization is a steric factor. The complex did not react with benzyl bromide or the aniline complex, but both the benzyl group and the $W(\mathrm{CO})_{5}$ molety are somewhat bulky. To prepare a positively charged complex of $\left(\mathrm{C}_{6} \mathrm{H}_{5}\right)_{2} \mathrm{PCH}_{2} \mathrm{P}\left(\mathrm{C}_{6} \mathrm{H}_{5}\right)_{2}$. Lodomethane was employed. First, one end of the ligand was quaternized to give $\left(\mathrm{C}_{6} \mathrm{H}_{5}\right)_{2} \mathrm{PCH}_{2} \stackrel{+}{\mathrm{P}}\left(\mathrm{C}_{6} \mathrm{H}_{5}\right)_{2} \mathrm{CH}_{3} \mathrm{I}^{-}$. The $\mathrm{smr}$ spectrum of this ligand is sho:m in Figure 14. The phosphorus-methyl proton coupling at 2.7 prom was $14.2 \mathrm{~Hz}$ and the quaternized phosphorusmethylene coupling was $15.6 \mathrm{~Hz}$. The trivalent phosphorus-methylene coupling was not resolved. When $\left(\mathrm{C}_{6} \mathrm{H}_{5}\right)_{2} \mathrm{PCH}_{2} \stackrel{+}{\mathrm{P}}\left(\mathrm{C}_{6} \mathrm{H}_{5}\right)_{2} \mathrm{CH}_{3} \mathrm{I}^{-}$was treated with a stoichiometric amount of $\mathrm{C}_{6} \mathrm{H}_{5} \mathrm{NH}_{2} \mathrm{~W}(\mathrm{CO})_{5}$, the desired positively chareed $(\mathrm{CO})_{5} \mathrm{iP}\left(\mathrm{C}_{6} \mathrm{H}_{5}\right)_{2} \mathrm{CH}_{2} \stackrel{+}{\mathrm{P}}\left(\mathrm{C}_{6} \mathrm{H}_{5}\right)_{2} \mathrm{I}^{-}$was obtained. The nmr spectrum of this complex (Figure 15) shows the phosphorusmethyl proton doublet of doublets centered at $4.8 \mathrm{ppm}$. In this case, both phosphorus nuclei are quaternized. The expanded spectrum (Figure 16) shows coupling of $18.6 \mathrm{~Hz}$ and $7.6 \mathrm{~Hz}$, but since there are no model compounds avallable for comparison, it is not possible to make definite assignments for these couplings. $\left(\mathrm{C}_{6} \mathrm{H}_{5}\right)_{2} \mathrm{PP}\left(\mathrm{C}_{6} \mathrm{H}_{5}\right)_{2}$ is an air sensitive 1 igand and was prepared as described in the experimental section. No characterizable compounds were isolated from the reaction of this ligand and the aniline complex. Attempts to prepare a positively charged complex of this ligand were thus abandoned.

A similar ligand which is not air sensitive is $\left(\mathrm{C}_{6} \mathrm{H}_{5}\right)_{2} \mathrm{PN}\left(\mathrm{C}_{2} \mathrm{H}_{5}\right)_{2}$. 
It was prepared from the reaction of $\left(\mathrm{C}_{6} \mathrm{H}_{5}\right)_{2} \mathrm{PCl}$ and $\left(\mathrm{C}_{2} \mathrm{H}_{5}\right)_{2} \mathrm{NH}$ in good yield. The nmr spectrum (Figure 17), a first order $\mathrm{XA}_{2} \mathrm{~N}_{3}$ system, shows $\mathrm{J}_{\mathrm{P}-\mathrm{N}-\mathrm{CH}_{2}}=9.8 \mathrm{~Hz}$ (expanded spectrum - Figure 18) with $\mathrm{J}_{\mathrm{CH}_{2}-\mathrm{CH}_{3}}=7.5 \mathrm{~Hz}$. This ligand reacts with $\mathrm{C}_{6} \mathrm{H}_{5} \mathrm{NH}_{2} \mathrm{~W}(\mathrm{CO})_{5}$ to produce in good yield $\left(\mathrm{CO}_{5}\right)_{5}\left(\mathrm{C}_{6} \mathrm{H}_{5}\right)_{2} \mathrm{PN}\left(\mathrm{C}_{2} \mathrm{H}_{5}\right)_{2}$. As amines do not displace aniline, only phosphorus becomes coordinated. The $\mathrm{nmr}$ spectrum (Figures 19 and 20) showed little change from the free ligand. The $\mathrm{P}-\mathrm{N}-\mathrm{CH}_{2}$ coupling increased to $11.6 \mathrm{~Hz}$ and the $\mathrm{CH}_{2}-\mathrm{CH}_{3}$ coupling value decreased to $7.2 \mathrm{~Hz}$. Attempts to quaternize the dangling diethylamino group were unsuccessful in that a character1zable compound was never isolated. Senzyl bromide and iodomethane did not react with $\left(\mathrm{CO}_{5}{ }_{5}{ }^{\mathrm{H}}\left(\mathrm{C}_{6} \mathrm{H}_{5}\right)_{2} \mathrm{PN}\left(\mathrm{C}_{2} \mathrm{H}_{5}\right)_{2}\right.$. Some infrared data suggested that quaternization occurred when $\left(\mathrm{C}_{2} \mathrm{H}_{5}\right)_{3} \mathrm{O}^{+} \mathrm{BF}_{4}^{-}$was used (Figure 21). The spectrum of the product is the same as that of $(\mathrm{CO})_{5} \mathrm{WP}\left(\mathrm{C}_{6} \mathrm{H}_{5}\right)_{2} \mathrm{~N}\left(\mathrm{C}_{2} \mathrm{H}_{5}\right)_{2}$ with an extra ${ }_{1}^{2} \mathrm{~A}$ band (the small one). Attempts to isolate this material gave an oil which still contained some neutral complex (Figure 22). Attempts to purify the compound were not successful and therefore this evidence is somewhat tenuous. Nurther efforts should be made to characterize the compound.

\section{B. Theoretical Aspects}

The carbonyl infrared stretching frequencies and calculated force constants are found in Table III.

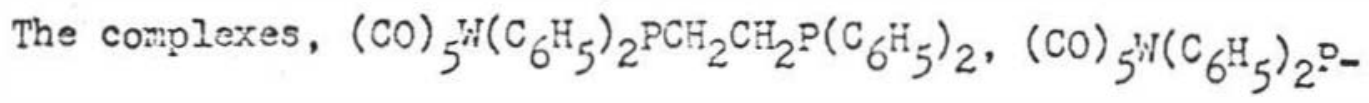


Table III. Infrared carbonyl stretching frequencies and force constants of monosubstituted pentacarbonyl complexes

\begin{tabular}{|c|c|c|c|c|c|c|c|c|}
\hline \multirow[b]{2}{*}{ Complex } & \multicolumn{4}{|c|}{$\mathrm{cm}^{-1}$} & \multicolumn{3}{|c|}{ mdynes $\mathrm{cm}^{-1}$} & \multirow[b]{2}{*}{ Iig. } \\
\hline & B & ${ }_{1}^{2} A$ & $1_{1}^{1}$ & $\mathbf{E}$ & $K_{1}$ & $K_{1}$ & $\mathrm{~K}_{2}$ & \\
\hline$(\mathrm{CO})_{5} \mathrm{~W}\left(\mathrm{C}_{6} \mathrm{H}_{5}\right)_{2} \mathrm{PCH}_{2} \mathrm{CH}_{2} \mathrm{P}\left(\mathrm{C}_{6} \mathrm{H}_{5}\right)_{2}$ & 1986 & 2074 & $1945^{*}$ & 1940 & 0.324 & 15.50 & 15.84 & 23 \\
\hline$(\mathrm{CO})_{5} \mathrm{~W}\left(\mathrm{C}_{6} \mathrm{H}_{5}\right)_{2} \mathrm{PCH}_{2} \mathrm{CH}_{2} \mathrm{P}\left(\mathrm{C}_{6} \mathrm{H}_{5}\right)_{2} \mathrm{~W}(\mathrm{CO})_{5}$ & 1983 & 2075 & $1947 *$ & 1942 & 0.322 & 15.53 & 15.87 & 24 \\
\hline$(\mathrm{CO})_{5} \mathrm{~W}\left(\mathrm{C}_{6} \mathrm{H}_{5}\right)_{2} \mathrm{PCH}_{2} \mathrm{CH}_{2} \stackrel{+}{\mathrm{P}}\left(\mathrm{C}_{6} \mathrm{H}_{5}\right)_{2}\left(\mathrm{CH}_{2} \mathrm{C}_{6} \mathrm{H}_{5}\right) \mathrm{PF}_{6}^{-}$ & 1990 & 2076 & $1943 *$ & 1938 & 0.338 & 15.44 & 15.81 & 25 \\
\hline$(\mathrm{CO})_{5} \mathrm{IV}\left(\mathrm{C}_{6} \mathrm{H}_{5}\right)_{2} \mathrm{PCH}_{2} \mathrm{P}\left(\mathrm{C}_{6} \mathrm{H}_{5}\right)_{2}$ & 1981 & 2072 & $1944 *$ & 1939 & 0.321 & 15.48 & 15.82 & 26 \\
\hline$(\mathrm{CO})_{5} \mathrm{~W}\left(\mathrm{C}_{6} \mathrm{H}_{5}\right)_{2} \mathrm{PCH}_{2} \stackrel{+}{\mathrm{P}}\left(\mathrm{C}_{6} \mathrm{H}_{5}\right)_{2} \mathrm{CH}_{3} \mathrm{I}$ & 1989 & 2078 & 1952 & 1938 & 0.336 & 15.63 & 15.84 & 27 \\
\hline$(\mathrm{CO})_{5} \mathrm{~W}\left(\mathrm{C}_{6} \mathrm{H}_{5}\right)_{2} \mathrm{PN}\left(\mathrm{C}_{2} \mathrm{H}_{5}\right)_{2}$ & - & 2077 & $1946 *$ & 1941 & 0.329 & 15.52 & 15.87 & 28 \\
\hline$(\mathrm{CO})_{5} \mathrm{WP}\left(\mathrm{C}_{6} \mathrm{H}_{5}\right)_{3}^{17}$ & 1981 & 2075 & $1947 *$ & 1942 & 0.322 & 15.53 & 15.87 & \\
\hline$(C O)_{5} \mathrm{WPF}_{3}^{4}$ & - & 2103 & 2007 & 1983 & 0.29 & 16.59 & 16.45 & \\
\hline
\end{tabular}

*Values were estimated to be $5 \mathrm{~cm}^{-1}$ larger than 8 as was estimated by R. J. Angelic1. 
$\mathrm{CH}_{2} \mathrm{CH}_{2} \mathrm{P}\left(\mathrm{C}_{6} \mathrm{H}_{5}\right)_{2} \mathrm{~W}(\mathrm{CO})_{5}$ and $\mathrm{W}(\mathrm{CO})_{5}\left(\mathrm{C}_{6} \mathrm{H}_{5}\right)_{2} \mathrm{PCH}_{2} \mathrm{CH}_{2} \stackrel{+}{\mathrm{P}}\left(\mathrm{C}_{6} \mathrm{H}_{5}\right)_{2}\left(\mathrm{CH}_{2} \mathrm{C}_{6} \mathrm{H}_{5}\right) \mathrm{PF}_{6}^{-}$ have essentially the same stretching frequencies and force constants. This is not too surprising as the second phosphorus atom is five bonds away from the nearest carbonyl group.

It is of interest that the Iigand $\left(\mathrm{C}_{6} \mathrm{H}_{5}\right)_{3} \mathrm{P}$ and $\left(\mathrm{C}_{6} \mathrm{H}_{5}\right)_{2} \mathrm{P}-$ $\mathrm{CH}_{2} \mathrm{CH}_{2}\left(\mathrm{C}_{6} \mathrm{H}_{5}\right)_{2}$ have very similar donor and acceptor properties. This agrees with the fact that $\left(\mathrm{C}_{6} \mathrm{H}_{5}\right)_{3} \mathrm{P}$ and $\left(\mathrm{C}_{6} \mathrm{H}_{5}\right)_{2} \mathrm{PCH}_{2} \mathrm{CH}_{2}\left(\mathrm{C}_{6} \mathrm{H}_{5}\right)_{2}$ are both stable in air whereas many phosphines are air sensitive. Tunsten-phosphorus coupling constants are a more sensitive probe to the metal-phosphorus bond strength than infrared data (see page 3). A P-31 spectrun has been obtained only for $\left(\omega_{0}\right) 5^{W-}$ $\left(\mathrm{C}_{6} \mathrm{H}_{5}\right)_{2} \mathrm{PCH}_{2} \mathrm{CH}_{2} \mathrm{P}\left(\mathrm{C}_{6} \mathrm{H}_{5}\right)_{2}$ (Figure 29). A tungsten-phosphorus coupling value of $270 \mathrm{~Hz}$ was recorded. The tungsten-phosphorus coupling value for $\left(\mathrm{C}_{6} \mathrm{H}_{5}\right)_{3} \mathrm{Pir}(\mathrm{CO})_{5}$ has been reported to be $270 \mathrm{~Hz}$.? This again shows the great similarity of the two ligands. The compound $\left(\mathrm{C}_{6} \mathrm{H}_{5}\right)_{2} \mathrm{C}_{2} \mathrm{H}_{5} \mathrm{Fil}(\mathrm{CO})$ (a complex of an air sensitive ligand) reported by Grim? ${ }^{17}$ has a W-P coupling constant of only $240 \mathrm{~Hz}$ which shows that it is a weaker ligand than either of tho two complexes. It is expected that the positively charged complex would show a somewhat higher $\mathrm{J}_{\mathrm{W}-\mathrm{P}}$ value.

The phosphorus-phosphorus coupling of $(\mathrm{CO})_{5} \mathrm{~W}^{\mathrm{N}}\left(\mathrm{C}_{6} \mathrm{H}_{5}\right)_{2} \mathrm{PCH}_{2} \mathrm{CH}_{2}-$ $\mathrm{P}\left(\mathrm{C}_{6} \mathrm{H}_{5}\right)_{2}(32.3 \mathrm{~Hz})$ is rather large. The $\mathrm{P}-31$ chemical shifts are relative to $\mathrm{P}_{4} \mathrm{O}_{6}$. The coordinated phosphorus value is $+98.7 \mathrm{ppm}$ and the dangling phosphorus value (Figure 30 ) is $+123.4 \mathrm{ppm}$. That the 
coordinated phosphorus is downfield from the uncoordinated phosphorus is in agreement with data of other tungsten-phosphorus systems. 18

No tungsten-phosphorus coupling constant values have been obtained for complexes of $\left(\mathrm{C}_{6} \mathrm{H}_{5}\right)_{2} \mathrm{PCH}_{2} \mathrm{P}\left(\mathrm{C}_{6} \mathrm{H}_{5}\right)_{2}$ because of a solubility problem. The carbonyl stretching frequencies and force constants for $(\mathrm{CO})_{5} \mathrm{~W}\left(\mathrm{C}_{6} \mathrm{H}_{5}\right)_{2} \mathrm{PCH}_{2} \mathrm{P}\left(\mathrm{C}_{6} \mathrm{H}_{5}\right)_{2}$ are very much like those for $(\mathrm{CO})_{5}{ }^{\mathrm{N}}\left(\mathrm{C}_{6} \mathrm{H}_{5}\right)_{2} \mathrm{PCH}_{2} \mathrm{CH}_{2} \mathrm{P}\left(\mathrm{C}_{6} \mathrm{H}_{5}\right)_{2}$, indicating the similarity of these ligands. However in the case of $\left(\mathrm{CO}_{5}{ }_{5}\left(\mathrm{C}_{6} \mathrm{H}_{5}\right)_{2} \mathrm{PCH}_{2} \stackrel{+}{\mathrm{P}}\left(\mathrm{C}_{6} \mathrm{H}_{5}\right)_{2}\right.$ $\mathrm{CH}_{3} \mathrm{I}^{-}$. the effect of the positive charge is shown. Here the cherge is four bonds from the neutral $\mathrm{CO}$, but the great sensitivity of carbonyl groups to electronic charge is evident. The co force constant $\left(k_{1}\right)$ for the ${ }^{1} A$ mode (corresponding to $C O$ opposite to the ligand) has become larger. A change of 0.15 mdynes $/ \mathrm{cm}$ is noted.

Finally, the carbonyl stretching frequencies and force constants for $(\mathrm{CO})_{5} \mathrm{WP}\left(\mathrm{C}_{6} \mathrm{H}_{5}\right)_{2} \mathrm{~N}\left(\mathrm{C}_{2} \mathrm{H}_{5}\right)_{2}$ aro similar to $\left(\mathrm{C}_{6} \mathrm{H}_{5}\right)_{2} \mathrm{P}-$

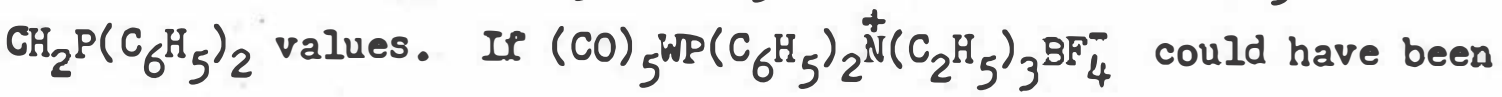
synthesized, a dramatic effect on $c 0$ force constants would probably have been noted.

The force constants are quite large for the $\left(\mathrm{PF}_{3}\right) \mathrm{W}(\mathrm{CO})_{5}$ complex. The values are $0.29,16.59$ and 16.45 mdynes $\mathrm{cm}^{-1}$. This shows that $\mathrm{PF}_{3}$ is a far better acceptor of electron density than is a positively charged lisand inth the charge in tho position $\beta$ 
to phosphorus.

\section{c. Sumoary}

In this study it has been shown that the ligand $\left(\mathrm{C}_{6} \mathrm{H}_{5}\right)_{2} \mathrm{P}-$ $\mathrm{CH}_{2} \mathrm{CH}_{2} \stackrel{+}{\mathrm{P}}\left(\mathrm{C}_{6} \mathrm{H}_{5}\right)_{2}\left(\mathrm{CH}_{2} \mathrm{C}_{6} \mathrm{H}_{5}\right) \quad \mathrm{PF}_{6}^{-}$forms a metal-phosphorus bond very much like $\left(\mathrm{C}_{6} \mathrm{H}_{5}\right)_{2} \mathrm{PCH}_{2} \mathrm{CH}_{2} \mathrm{P}\left(\mathrm{C}_{5} \mathrm{H}_{5}\right)_{2}$. It has also been shown that $\left(\mathrm{C}_{6} \mathrm{H}_{5}\right)_{2} \mathrm{PCH}_{2} \stackrel{+}{\mathrm{P}}\left(\mathrm{C}_{6} \mathrm{H}_{5}\right)_{2} \mathrm{CH}_{3} \mathrm{I}^{-}$is a slightly better ligand than $\left(\mathrm{C}_{6} \mathrm{H}_{5}\right)_{2}{ }^{\mathrm{PCH}}{ }^{\mathrm{P}}\left(\mathrm{C}_{6} \mathrm{H}_{5}\right)_{2}$.

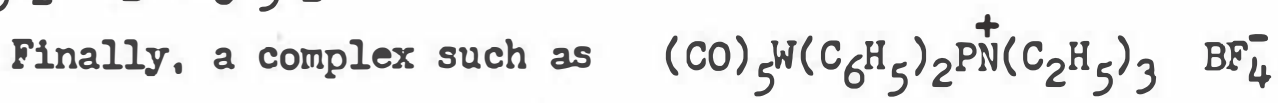
could not be synthesized and so the effect of a positive charge in the $\alpha$ position is yet unknown.

Synthetically, it was found that $\left(\mathrm{C}_{6} \mathrm{H}_{5}\right)_{2} \mathrm{PCH}_{2} \mathrm{CH}_{2} \mathrm{P}\left(\mathrm{C}_{6} \mathrm{H}_{5}\right)_{2}$ reacts with $\mathrm{C}_{6} \mathrm{H}_{5} \mathrm{NH}_{2} \mathrm{~W}(\mathrm{CO})_{5}$ to form $(\mathrm{CO})_{5}{ }_{5}\left(\mathrm{C}_{6} \mathrm{H}_{5}\right)_{2} \mathrm{PCH}_{2} \mathrm{CH}_{2} \mathrm{P}\left(\mathrm{C}_{6} \mathrm{H}_{5}\right)_{2-}$ $\mathrm{W}(\mathrm{CO})_{5}$ and $(\mathrm{CO})_{5} \mathrm{~W}\left(\mathrm{C}_{6} \mathrm{H}_{5}\right)_{2} \mathrm{PCH}_{2} \mathrm{CH}_{2}\left(\mathrm{C}_{6} \mathrm{H}_{5}\right)_{2}$. The dimetallic complex is favored and a large excess of free ligand is needed to form the monometallic complex in good yield. The monometallic complex may be quaternized with benzyl bromide. In the reaction of $\mathrm{C}_{6} \mathrm{H}_{5} \mathrm{NH}_{2} \mathrm{~W}-$ $(\mathrm{CO})_{5}$ with $\left(\mathrm{C}_{6} \mathrm{H}_{5}\right)_{2} \mathrm{PCH}_{2} \mathrm{P}\left(\mathrm{C}_{6} \mathrm{H}_{5}\right)_{2}$, there is no tendency for the dimetallic complex to form even when the aniline complex is present in excess. Nor is the monometallic complex quaternized by benzyl bromide. That steric factors are present here is suggested by the fact that quaternization with $\mathrm{CH}_{3} \mathrm{I}$ takes place.

Electronically, $\left(\mathrm{C}_{6} \mathrm{H}_{5}\right)_{2} \mathrm{PCH}_{2} \mathrm{CH}_{2} \mathrm{P}\left(\mathrm{C}_{6} \mathrm{H}_{5}\right)_{2}$ and $\left(\mathrm{C}_{6} \mathrm{H}_{5}\right)_{3} \mathrm{P}$ are very similar ligands. When coordinated to $\mathrm{W}(\mathrm{CO})_{5}$, nearly identical 
force constants and co stretching frequencies are obtained, and Identical values of tungsten-phosphorus coupling constants are found. Infrared data support the formation of $(\mathrm{CO})_{4} \mathrm{Brin} \cdot\left(\mathrm{C}_{6} \mathrm{H}_{5}\right)_{2}-$

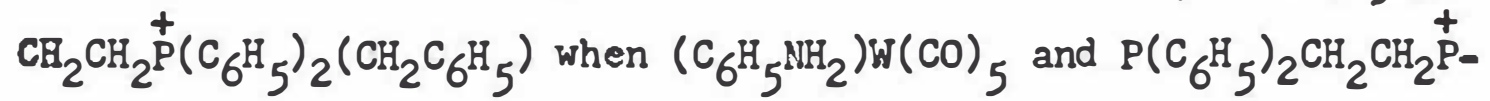
$\left(\mathrm{C}_{6} \mathrm{H}_{5}\right)_{2} \mathrm{CH}_{2} \mathrm{C}_{6} \mathrm{H}_{5} \mathrm{Br}^{-}$are allowed to react in methanol. 
CHAPTER III

\section{EXPERIMENTAL}

\section{A. General considerations}

Microanalyses were performed by Galbraith Laboratories. Knoxville, Tennessee.

Phosphorus-31 rms spectra were measured with a Varian S-T60 nmr equipped with a phosphorus probe and a time averaging computer. These measurements were performed by Varian Associates, Palo Alto. California. An external reference of $\mathrm{P}_{4} \mathrm{O}_{6}$ was employed. By convention, chemical shifts upfield from $\mathrm{P}_{4} \mathrm{O}_{6}$ are assigned a positive value and all chemical shifts downfield are given a negative value.

Proton Imr spectra were measured with a Varian S-T60 spectrometer. Saturated deuteriochloroform solutions containing tetramethylsilane as an internal reference were used for all ligands and complexes.

Infrared spectra in the carbonyl region were recorded with a Perkin-Elmer 337 grating infrared spectrometer. Expanded spectra were recorded with an E. H. Sargent recorder SR, and are considered to be accurate to $\pm 2 \mathrm{~cm}^{-1}$.

Melting points were taken with an Arthur H. Thomas Unimelt 
apparatus, and are reported uncorrected.

\section{B. Preparation of Ligands}

1. 1,2-3isdiphenylphosphinoethane, $\left(\mathrm{C}_{6} \mathrm{H}_{5}\right)_{2} \mathrm{PCH}_{2} \mathrm{CH}_{2} \mathrm{P}\left(\mathrm{C}_{6} \mathrm{H}_{5}\right)_{2}{ }^{10}$

Triphenylphosphine $(50.0 \mathrm{~g}, 0.19 \mathrm{~mole})$ was dissolved in 500 ml of anhydrous tetrahydrofuran (THF) which contained lithium metal $(3.0 \mathrm{~g}, 0.432$ mole). The solution was stirred for three hours, and a dark red solution of lithiumdiphenylphosphide (LiP$\left.\left(\mathrm{C}_{6} \mathrm{~B}_{5}\right)_{2}\right)$ and phenyllithium $\left(\mathrm{C}_{6} \mathrm{H}_{5} \mathrm{Li}\right)$ resulted. A solution of t-butylchloride $(17.6 \mathrm{~g}, 0.19$ mole) was added to destroy the phenyllithium. The resulting solution was cooled to $0^{\circ} \mathrm{C}$, and 1,2-dichloroethane $(18.8 \mathrm{~g}, 0.19$ mole) was added in small portions over one hour. The solution was stirred for 5 hours, and $200 \mathrm{ml}$ of water was added to remove the inorganic layer. After separation, THF was removed from the organic layer with a rotary evaporator. Sufficient petroleum ether $\left(30^{\circ}-60^{\circ} \mathrm{C}\right)$ was added to the resulting oil to crystallize the product. The product (yield 40,8) was recrystallized from absolute alcohol (mp $141^{\circ} \mathrm{C}^{11}$ ). 2. Bis(diphenylphosphino)methane, $\left(\mathrm{C}_{6} \mathrm{H}_{5}\right)_{2} \mathrm{PCH}_{2} \mathrm{P}\left(\mathrm{C}_{6} \mathrm{H}_{5}\right)_{2}$

This ligand was prepared by a modification of the procedure for the ethane analog.

To a solution of lithium diphenylphosphide at $0^{\circ} \mathrm{C}$ was added dibromomethane $(33.0 \mathrm{~g}, 0.19$ mole) over a period of one hour. The solution was stirred for 5 hours, and $200 \mathrm{ml}$ of water was added to 
remove the inorganic layer. After separation, tetrahydrofuran (THF) was removed from the organic layer with a rotary evaporator. Sufficient petroleum ether $\left(30-60^{\circ} \mathrm{C}\right)$ was added to the resulting 011 to crystallize the product. The product (yield 50,\%) was recrystallized from absolute alcohol (mp $121^{\circ} \mathrm{C}^{12}$ ).

3. Tetraphenylbiphosphine, $\left(\mathrm{C}_{6} \mathrm{H}_{5}\right)_{2} \mathrm{PP}\left(\mathrm{C}_{6} \mathrm{H}_{5}\right)_{2}$

This air sensitive compound is generally made from lithiumdiphenylphosphide and chlorodiphenylphosphine. ${ }^{3}$ After mixing the two reactants in tetrahydrofuran ( $T H F$ ), the solution is extracted with ether and the organic layer is separated. The ether is re. moved from the organic layer by evaporation urder an inert atmosphere to give the desired product.

By accident, in the first stage of the preparation, glycerol (used in a nitrogen bubbler) was draisn into a solution containing lithiumdiphenylphosphide.

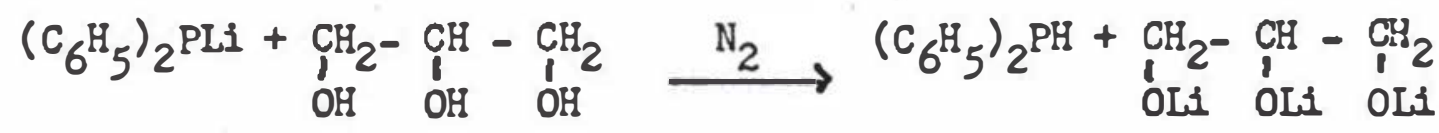

The lithium salt of glycerol was destroyed by adding distilled water.

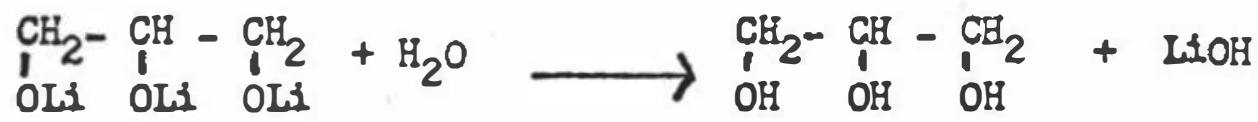

The aqueous layer containing glycerol was separated from the THF layer. The THF was distilled and $\left(\mathrm{C}_{6} \mathrm{H}_{5}\right)_{2} \mathrm{PH}$ was distilled at $125^{\circ} \mathrm{C}$ ( 0.05 torr). All the operations were done under nitrogen. Chlorodiphenylphosphine (22.23 E, 0.119 mole) was added to 
diphenylphosphine $(26.40 \mathrm{~g}, 0.119$ mole) to yield a white tetraphenylbiphosphine (yield $35.7 \mathrm{~g}, 80 \%$ ). The compound was stored under nitrogen.

4. 1-Diphenylphosphino-2-benzyldiphenylphosphonium-ethane bromide, $\left(\mathrm{C}_{6} \mathrm{H}_{5}\right)_{2} \mathrm{PCH}_{2} \mathrm{CH}_{2} \stackrel{+}{\mathrm{P}}\left(\mathrm{C}_{6} \mathrm{H}_{5}\right)_{2} \mathrm{CH}_{2} \mathrm{C}_{6} \mathrm{H}_{5} \mathrm{Br}^{-}$

This ligand was prepared by treating $\left(\mathrm{C}_{6} \mathrm{H}_{5}\right)_{2} \mathrm{PCH}_{2} \mathrm{CH}_{2} \mathrm{P}\left(\mathrm{C}_{6} \mathrm{H}_{5}\right)_{2}$ $(1.0 \mathrm{~g}, 0.0025 \mathrm{~mole})$ in acetone $(25 \mathrm{ml})$ with a stoichiometric quantity of benzylbromide $(0.44 \mathrm{~g}, 0.0025 \mathrm{~mole})$. The white solid which separated after several hours was washed with acetone and recrystallized by dissolving it in isobutylalcohol and reprecipitating with hexane (yield $1.05 \mathrm{~g}, 74 \%$ ). The pure product was obtained as whito crystals ( $m p 240-245^{\circ} \mathrm{C}$ ).

5. 1-Diphenylphosphino-1-benzyldiphenylphosphonium-methane bromide. $\underbrace{}_{\left(\mathrm{C}_{6} \mathrm{H}_{5}\right)_{2} \mathrm{PCH}_{2} \stackrel{+}{\mathrm{P}}\left(\mathrm{C}_{6} \mathrm{H}_{5}\right)_{2} \mathrm{CH}_{2} \mathrm{C}_{6} \mathrm{H}_{5} \mathrm{Br}^{-}}$

This ligand was prepared by treating $\left(\mathrm{C}_{6} \mathrm{H}_{5}\right)_{2} \mathrm{PCH}_{2}\left(\mathrm{C}_{6} \mathrm{H}_{5}\right)_{2}$ $(1.0 \mathrm{~g}, 0.0026 \mathrm{~mole})$ in acetone $(25 \mathrm{ml})$ with the stoichiometric quantity of benzylbromide $(0.42 \mathrm{~g}, 0.0026 \mathrm{~mole})$. The white solid which separated after several hours was washed with acetone and recrystallized by dissolving it in isobutylalcohol and reprecipitating with hexane (yield $1.03 \mathrm{~g}, 71 \mathrm{f}$ ). The pure product was obtained as white crystals (mp $230.235^{\circ} \mathrm{C}$ ). 6. 1-Diphenylphosphino-1-methyldiphenylphosphonium-methane 1odide, $\left(\mathrm{C}_{6} \mathrm{H}_{5}\right)_{2} \mathrm{PCH}_{2} \stackrel{+}{\mathrm{P}}\left(\mathrm{C}_{6} \mathrm{H}_{5}\right)_{2} \mathrm{CH}_{3} \mathrm{I}^{-}$

This $\mathrm{H}_{\mathrm{g}}$ and was prepared by treating a solution of $\left(\mathrm{C}_{6} \mathrm{H}_{5}\right)_{2} \mathrm{PCH}_{2}-$ 
$P\left(\mathrm{C}_{6} \mathrm{H}_{5}\right)_{2}(1.0 \mathrm{~g}, 0.002 \mathrm{~mole})$ in benzene $(25 \mathrm{ml})$ with iodomethane $(0.369 \mathrm{~g}, 0.0026 \mathrm{~mole})$. The white solid separated after several bours. The yield was essentially stoichiometric. 7. Diethylaminod iphenylphosphine. $\left(\mathrm{C}_{2} \mathrm{H}_{5}\right)_{2} \mathrm{NP}\left(\mathrm{C}_{6} \mathrm{H}_{5}\right)_{2}^{14}$

Diethylanine $(73.0 \mathrm{~g}, 1.0 \mathrm{~mole})$ in dry ether $(10.0 \mathrm{ml})$ was added dropwise, with stirring, to chlorodiphenylphosphine (83 g. $0.38 \mathrm{~mole}$ ) in $300 \mathrm{ml}$ of dry other at room temperature. Entry of air into the mixture was prevented by the use of a nitrogen strearu. The mixture was stirred for 1 hour to ensure an easily filterable precipitate. The hydrochloride was separated by filtration under altrogen and washed with dry ether. The washings were combined with the filtrate, and the other was removed by distillation. The fraction boiling at $165^{\circ} \mathrm{C}$ (2.0 torr) was collected as the required product (yield $34 \mathrm{~g}, 64 \%$ ).

C. Preparation of Neutral Complexes

1. Anilinepentacarbonyltungsten, $\mathrm{C}_{6} \mathrm{H}_{5} \mathrm{NH}_{2} \mathrm{~W}(\mathrm{CO})_{5}{ }^{1}$

Tungstenhexacarbonyl $(8.7 \mathrm{~g}, 0.024 \mathrm{~mole})$ and aniline $(10.0 \mathrm{~g}$, $0.10 \mathrm{~mole}$ ) were dissolved in $500 \mathrm{ml}$ of dry tetrahydrofuran (THF) and irradiated with uv light for 7 hours. (A diazram of the irradlation cell is found in Appendix II). The resulting yellow solution was evaporated to a thick oil, and water and dilute hydrochloric acid were added until the oil becarne a yellow solid. Excess $W(C O)_{6}$ was removed by sublimation (yield $87 \mathrm{~g}, 87.9,0$ ). 
2. Bis (diphenylphosphino) ethanepentacarbonyltungsten(0),

$\left(\mathrm{CO}_{5}{ }_{5} \mathrm{~N}\left(\mathrm{C}_{6} \mathrm{H}_{5}\right)_{2} \mathrm{PCH}_{2} \mathrm{CH}_{2} \mathrm{P}\left(\mathrm{C}_{6} \mathrm{H}_{5}\right)_{2}\right.$

This complex was prepared by dissolving $\left(\mathrm{C}_{6} \mathrm{H}_{5}\right)_{2} \mathrm{PCH}_{2} \mathrm{CH}_{2} \mathrm{P}\left(\mathrm{C}_{6} \mathrm{H}_{5}\right)_{2}$ $(3.0 \mathrm{~g}, 0.0075 \mathrm{~mole})$ in $100 \mathrm{ml}$ of benzene. To this solution was added $W(\mathrm{CO})_{5} \mathrm{C}_{6} \mathrm{H}_{5} \mathrm{NH}_{2}(1.0 \mathrm{~g}, 0.0023$ mole $)$. The solution was allowed to stand for 12 hours at room temperature, and was taken to a thick oil with a rotary evaporator. The oil was dissolved in dichloromethane, and an equal volume of methanol was added. The solution was cooled to $5^{\circ} \mathrm{C}$, and white crystals slowly formed. These crystals were recrystallized from methanol (yield $1.8 \mathrm{~g}, 33 \%$ ) (mp 116.117 ${ }^{\circ} \mathrm{C}$ ). 3. Bis (diphenylphosphino) ethanebis (pentacarbonyltungsten)(0), $\underline{\left(\mathrm{W}(\mathrm{CO})_{5}\left(\mathrm{C}_{6} \mathrm{H}_{5}\right)_{2} \mathrm{PCH}_{2} \mathrm{CH}_{2} \mathrm{P}\left(\mathrm{C}_{6} \mathrm{H}_{5}\right)_{2} \mathrm{~W}(\mathrm{CO})_{5}\right.}$

This complex was prepared as the preceding one except that the mole ratio was $1: 1$ (ligand to aniline complex).

$$
\left(\mathrm{C}_{6} \mathrm{H}_{5}\right)_{2} \mathrm{PCH}_{2} \mathrm{CH}_{2} \mathrm{P}\left(\mathrm{C}_{6} \mathrm{H}_{5}\right)_{2}(6.8 \mathrm{~g}, 0.017 \text { mole) was dissolved in }
$$
$100 \mathrm{ml}$ of benzene, and $W(\mathrm{CO})_{5} \mathrm{C}_{6} \mathrm{H}_{5} \mathrm{NH}_{2}(6.0 \mathrm{~g}, 0.014 \mathrm{~mole})$ was added to the solution. The solution was allowed to stand for 12 hours at room tconperature and was then taken to a thick oil with a rotary evaporator. The oil was dissolved in dichloromethane, and an equal volume of methanol was added. The solution was cooled to $5^{\circ} \mathrm{C}$, and white crystals slowly formed. These crystals were recrystallized from methanol $\left(\operatorname{dec} 205-206^{\circ} \mathrm{C}\right.$ ). 4. Bis(diphenylphosphino)methanepentacarbonyltungsten $(0)$, $\left(\mathrm{C}_{6} \mathrm{H}_{5}\right)_{2} \mathrm{PCH}_{2} \mathrm{P}\left(\mathrm{C}_{6} \mathrm{H}_{5}\right)_{2} \mathrm{H}(\mathrm{CO})_{5}$ 
Th1s complex was prepared by dissolving $\left(\mathrm{C}_{6} \mathrm{H}_{5}\right)_{2} \mathrm{PCH}_{2} \mathrm{P}\left(\mathrm{C}_{6} \mathrm{H}_{5}\right)_{2}$ (1.2 g. 0.003 mole) in $25 \mathrm{ml}$ of acetone and treating it with $W(\mathrm{CO})_{5} \mathrm{C}_{6}{ }_{5} \mathrm{NH}_{2}(0.43 \mathrm{~g}, 0.0013 \mathrm{~mole})$ in $50 \mathrm{ml}$ of benzene. After 24 hours, the benzene was removed and a thick oil resulted. The oil was dissolved in equal volumes of dichloromethane and methanol. The solution was cooled to $5^{\circ} \mathrm{C}$, and white crystals slowly formed. These crystals were recrystallized from methanol (yield $0.8 \mathrm{~g}$, $37 \AA)\left(\operatorname{dec} 188-189^{\circ} \mathrm{C}\right)$.

Anal. Caled. for $\mathrm{C}_{29} \mathrm{H}_{27} \mathrm{O}_{5} \mathrm{P} 2^{\mathrm{W}:}$ C. 50.60; H. 3.17; P. 8.87. Found: C, 50.87; H, 3.13; P, 8.74.

5. Diethylaminodiphenylphosphinopentacarbonyltungsten $(0)$, $\mathrm{W}(\mathrm{CO})_{5} \mathrm{P}\left(\mathrm{C}_{6} \mathrm{H}_{5}\right)_{2} \mathrm{~N}\left(\mathrm{C}_{2} \mathrm{H}_{5}\right)_{2}$

Diethylaminodiphenylphosphine $(2.50 \mathrm{~g}, 0.0097 \mathrm{~mole})$ and $\mathrm{C}_{6} \mathrm{H}_{5} \mathrm{NH}_{2} \mathrm{~W}(\mathrm{CO})_{5}(4.35 \mathrm{~g}, 0.010 \mathrm{~mole})$ were mixed in $50 \mathrm{ml}$ of benzene. The solution was allowed to stand for 24 hours at room temperature and was then taken to a thick oil with a rotary evaporator. The oll was dissolved in equal volumes of dichloromethane and methanol. This was cooled to $5^{\circ} \mathrm{C}$, and yellow crystals slowly formed. These crystals were recrystallized from methanol to give white crystals (yield $2.8 \mathrm{~g}, 49 \%$ ) (mp $84-85^{\circ} \mathrm{C}$ ).

\section{Preparation of Positively Charged Complexes}

1. 1-Diphenylohosphino-2-benzyldiphenylphosphonium-ethanepentacarbonyltungsten(0) bromide, $\mathrm{W}(\mathrm{CO})_{5}\left(\mathrm{C}_{6} \mathrm{H}_{5}\right)_{2} \mathrm{PCH}_{2} \mathrm{CH}_{2} \stackrel{+}{\mathrm{P}}\left(\mathrm{C}_{6} \mathrm{H}_{5} \mathrm{CH}_{2}\right) \quad \mathrm{Br}^{-}$ 
This complex was prepared by treating $(\mathrm{CO})_{5} \operatorname{VIP}\left(\mathrm{C}_{6} \mathrm{H}_{5}\right)_{2} \mathrm{CH}_{2} \mathrm{CH}_{2}-$ $P\left(C_{6} \mathrm{H}_{5}\right)_{2}(1.0 \mathrm{~g}, 0.0014 \mathrm{~mole})$ with benzylbromide $(0.237 \mathrm{~g}, 0.0014$ mole) in benzene. The white solid which separated after several hours of stirring was washed with benzene (yield $1.2 \mathrm{~g}, 96 \%$ ). Anal. Caled. for $\mathrm{C}_{38} \mathrm{H}_{3} \mathrm{P}_{2} \mathrm{NO}_{5} \mathrm{Br}:$ C. 50.54; $\mathrm{H}, 3.32$; $\mathrm{Br}, 9.09 ; \mathrm{P}$, 7.04. Found: C. 54.39; H, 4.28; Br, 10.67; P, 7.01.

2. 1-Diphenylphosphino-2-benzyldiphenylphosphonium-ethanepentacarbonyltungsten(O) hexafluorophosphate, $\mathrm{W}(\mathrm{CO})_{5}\left(\mathrm{C}_{6} \mathrm{H}_{5}\right)_{2} \mathrm{PCH}_{2} \mathrm{CH}_{2} \stackrel{+}{\mathrm{P}}\left(\mathrm{C}_{6} \mathrm{H}_{5}\right)_{2}^{-}$ $\left(\mathrm{C}_{6} \mathrm{H}_{5} \mathrm{CH}_{2}\right) \mathrm{PF}_{6}^{-}$

This complex was prepared by mixing $W(\mathrm{CO})_{5}\left(\mathrm{C}_{6} \mathrm{H}_{5}\right)_{2} \mathrm{PCH}_{2} \mathrm{CH}_{2} \stackrel{+}{\mathrm{P}_{-}}$ $\left(\mathrm{C}_{6} \mathrm{H}_{5} \mathrm{CH}_{2}\right) \mathrm{Br}^{-}(0.8 \mathrm{~g}, 0.0009$ mole $)$ with $50 \mathrm{ml}$ of water and treating the mixture with ammoniun hexafluorophosphate, $\left(\mathrm{NH}_{4}\right) \mathrm{PF}_{6}(0.3 \mathrm{~g}$. 0.0018 mole). The white product which formed was washed with water and dried under vacuum (yield $0.8 \mathrm{~g}, 92 \mathrm{~g}$ ) (dec $175-185^{\circ} \mathrm{C}$ ). Anal. Calcd. for $\mathrm{C}_{38} \mathrm{H}_{31} \mathrm{P}_{3} \mathrm{WO}_{5} \mathrm{~F} 6$ : C. 47.62; $\mathrm{H}, 3.26 ; \mathrm{P}, 9.69 ; \mathrm{F}, 11.89$. Found: C, 47.37; H, 3.29; P, 9.71; F, 11.59 . 3. 1-Diphenylphosphino-2-methyldiphenylphosphonium-methanepentacarbonyltungsten(O) iodide, $\mathrm{W}(\mathrm{CO})_{5}\left(\mathrm{C}_{6} \mathrm{H}_{5}\right)_{2} \mathrm{PCH}_{2} \stackrel{+}{\mathrm{P}}\left(\mathrm{C}_{6} \mathrm{H}_{5}\right)_{2} \mathrm{CH}_{3} \mathrm{I}^{-}$ This complex was prepared by dissolving $\left(\mathrm{C}_{6} \mathrm{H}_{5}\right)_{2} \mathrm{PCH}_{2} \stackrel{+}{\mathrm{P}}\left(\mathrm{C}_{6} \mathrm{H}_{5}\right)_{2}-$ $\mathrm{CR}_{3} \mathrm{I}^{-}(1.367 \mathrm{~g}, 0.0026 \mathrm{~mole})$ in chloroform $(25 \mathrm{ml})$ and treating with $\mathrm{NH}_{2} \mathrm{C}_{6} \mathrm{H}_{5} \mathrm{il}(\mathrm{CO})_{5}(1.0842 \mathrm{~g}, 0.0026 \mathrm{~mole})$. The solution was allowed to stand for 12 hours at room temperature and was then taken to a thick oil with a rotary evaporator. Extraction of the 
oil with benzene left the desired compound as a white solid (dec $145-150^{\circ} \mathrm{C}$ ).

\section{B. Attempted Preparations}

1. Triethyldiphenylphosphinoammoniump ntacarbonyltungsten $(0)$ tetraPluoroborate. $\left.\left(\mathrm{C}_{6} \mathrm{H}_{5}\right)^{\mathrm{W}(\mathrm{CO})}\right)^{\mathrm{PN}\left(\mathrm{C}_{2} \mathrm{H}_{5}\right)_{3}} \quad \mathrm{BF}_{4}^{-}$ The $\left(\mathrm{C}_{2} \mathrm{H}_{5}\right)_{3} \mathrm{O}^{+} \mathrm{BF}_{4}^{-}$was prepared according to Mecrwin.

$$
\begin{aligned}
& 4\left(\mathrm{C}_{2} \mathrm{H}_{5}\right)_{2} \mathrm{OBF}_{3}+2\left(\mathrm{C}_{2} \mathrm{H}_{5}\right)_{2} \mathrm{O}+3 \mathrm{ClCH}_{-} \mathrm{CH}_{0}-\mathrm{CH}_{2} \longrightarrow
\end{aligned}
$$

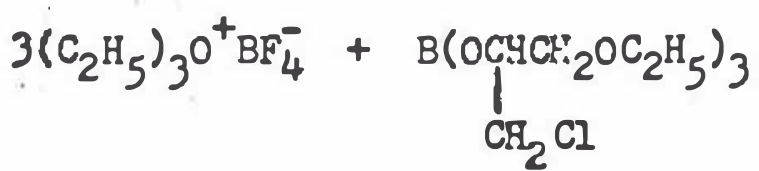

Sodium dried ether $(250 \mathrm{ml})$ and $126 \mathrm{ml}(1.0 \mathrm{~mole})$ of freshly distilled fluoride etherate were placed in a flask. Epichlorohydrin ( $60 \mathrm{ml}, 0.75 \mathrm{~mole}$ ) was added dropwise for 1 hour, and the mixture was stirred at a sufficient rate to allow it to reflux. The white crystals which formed were washed with dry ether and dried under vacuum. All the operations were performed under nitrogen. The triethyloxoniumfluoroborate was colorless (g1eld $120 \mathrm{~g}, 85$, ) (mp 92-92 ${ }^{\circ} \mathrm{C}$ ).

$$
\mathrm{W}(\mathrm{CO})_{5}\left(\mathrm{C}_{6} \mathrm{H}_{5}\right)_{2} \mathrm{PN}\left(\mathrm{C}_{2} \mathrm{H}_{5}\right)_{2}(2.0 \mathrm{~g}, 0.0034 \mathrm{~mole}) \text { was dissolved }
$$

in $30 \mathrm{ml}$ of benzene, and $\left(\mathrm{C}_{2} \mathrm{H}_{5}\right)_{3} \mathrm{O}^{+} \mathrm{BF}_{4}^{-}$was added to the solution wh1ch was stirred for 12 hours under nitrogen. No reaction occurred. The solution was then heated under reflux for 6 hours. An $\sin$ of the solution showed that only starting material was 
present.

The same reaction was attempted with other solvents, such as methanol, chloroform, acetone, ether and methylene chloride, but no significant changes were observed.

$$
(\mathrm{CO})_{5} \mathrm{~W}\left(\mathrm{C}_{6} \mathrm{H}_{5}\right)_{2} \mathrm{PN}\left(\mathrm{C}_{2} \mathrm{H}_{5}\right)_{2}(0.8 \mathrm{~g}, 0.0014 \mathrm{~mole}) \text { and }\left(\mathrm{CH}_{3} \mathrm{CH}_{2}\right)_{3} \mathrm{O}^{+}
$$

$\mathrm{BF}_{4}^{-}$(excess) were heated under nitrogen until molten in an oil bath at $95^{\circ} \mathrm{C}$ for 15 minutes. The oily mass was extracted with petroleum ether and benzene. Nost of the mixture did not dissolve. The insoluble oil was extracted with chlorofomn and taken to an oil with a rotary evaporator. The oil showed a very promising carbonyl stretching frequency in the infrared spectrum. An nar of the oil showed that very little starting material was present. Several attempts at crystallizing this oil by various methods failed.

2. Benzyldiethyldiphenylphosphinoammoniumpentacarbonyltungsten(0) bromide, $\left(\mathrm{C}_{2} \mathrm{H}_{5}\right)_{2}\left(\mathrm{C}_{6} \mathrm{H}_{5} \mathrm{CH}_{2}\right) \stackrel{+}{\mathrm{N} P}\left(\mathrm{C}_{6} \mathrm{H}_{5}\right)_{2} \mathrm{~W}(\mathrm{CO})_{5} \mathrm{Br}^{-}$ $\mathrm{l}(\mathrm{CO}){ }_{5}\left(\mathrm{C}_{6} \mathrm{H}_{5}\right)_{2} \mathrm{PN}\left(\mathrm{C}_{2} \mathrm{H}_{5}\right)_{2}(2.0 \mathrm{~g}, 0.0034$ mole $)$ was dissolved in $30 \mathrm{ml}$ of benzene, and benzylbromide ( $1.76 \mathrm{~g}, 0.010 \mathrm{~mole})$ was added. The solution was stirred for 12 hours under nitrogen. No reaction occurred. The solution was then heated under reflux for 6 hours. Starting material was recovered. 3. Methyldiethyldiphenylphosphinoammoniumpentacarbonyltungs ten(0) iodide, $\left.\left(\mathrm{CH}_{3}\right)\left(\mathrm{C}_{2} \mathrm{H}_{5}\right)_{2} \mathrm{NP}\left(\mathrm{C}_{6} \mathrm{H}_{5}\right)_{2} \mathrm{W(CO}\right)_{5} \mathrm{I}^{-}$ 


$$
w(\mathrm{CO})_{5}\left(\mathrm{C}_{6} \mathrm{H}_{5}\right)_{2} \mathrm{PN}\left(\mathrm{C}_{2} \mathrm{H}_{5}\right)_{2}(1.8 \mathrm{~g}, 0.0030 \text { mole }) \text { was dissolved }
$$
In benzene, and methyl lodide $(11.3 \mathrm{~g}, 0.08$ mole) was added. The solution was heated under reflux for several hours. No reaction occurred. Starting material was recovered. The neutral complex was dissolved in pure methyl iodide. No change in tho our spectrum appeared after 24 hours. 


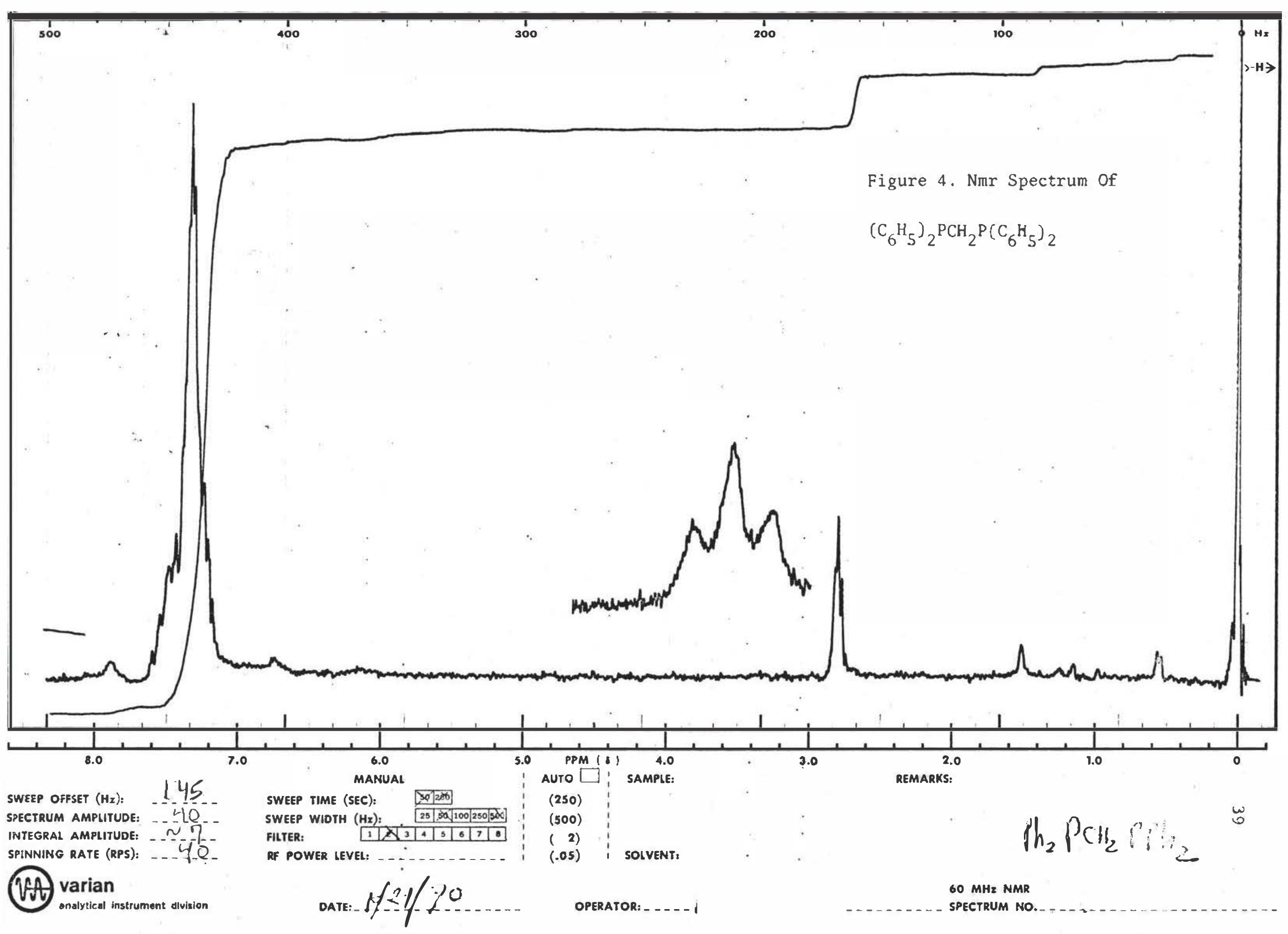


40

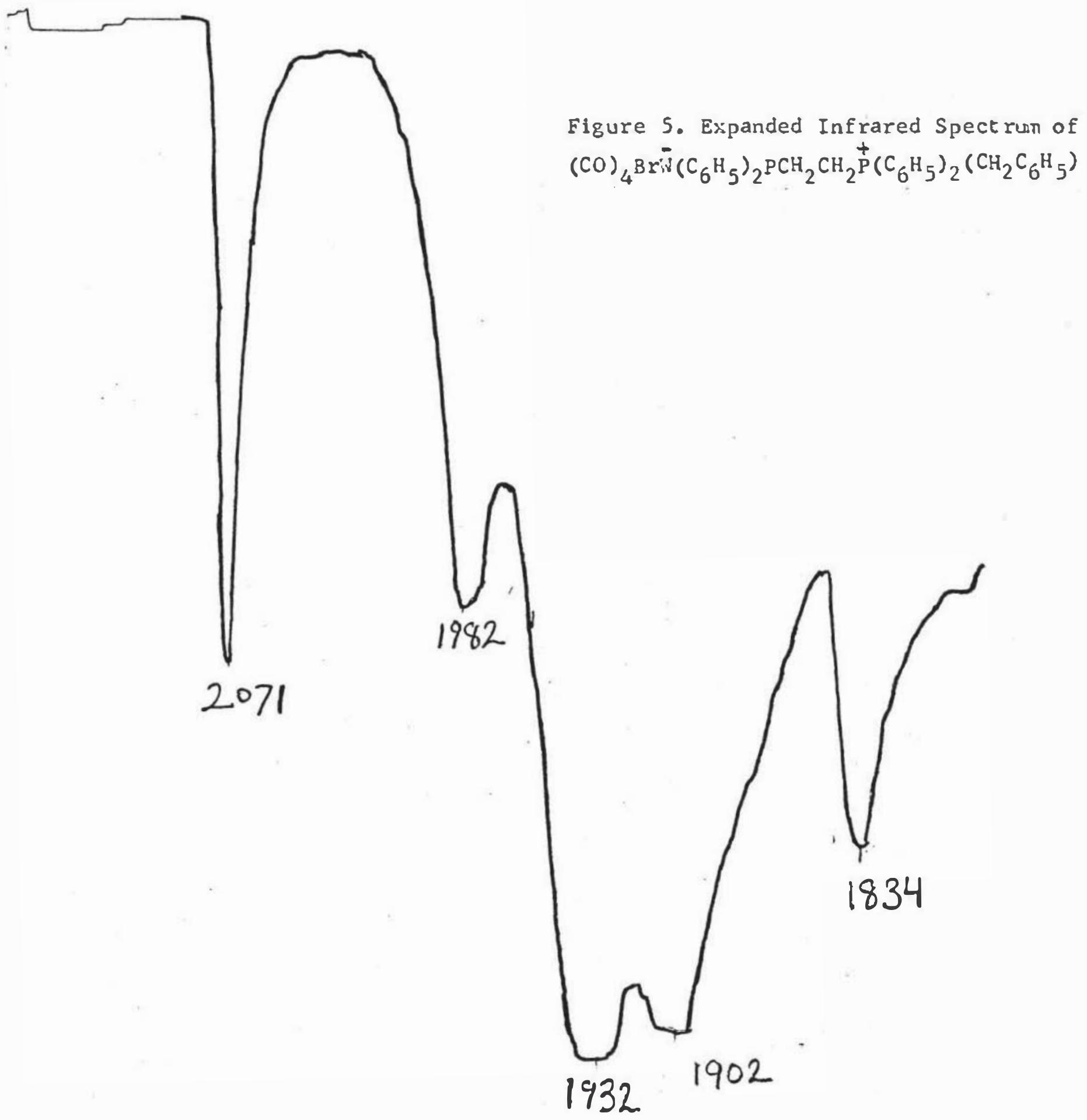


41

Figure 6. Expanded Infrared spectrum of $(\mathrm{CO})_{4} \mathrm{Br} \bar{W}\left(\mathrm{C}_{6} \mathrm{H}_{5}\right)_{2} \mathrm{PCH}_{2} \stackrel{+}{\mathrm{P}}\left(\mathrm{C}_{6} \mathrm{H}_{5}\right)_{2}\left(\mathrm{CH}_{2} \mathrm{C}_{6} \mathrm{H}_{5}\right)$

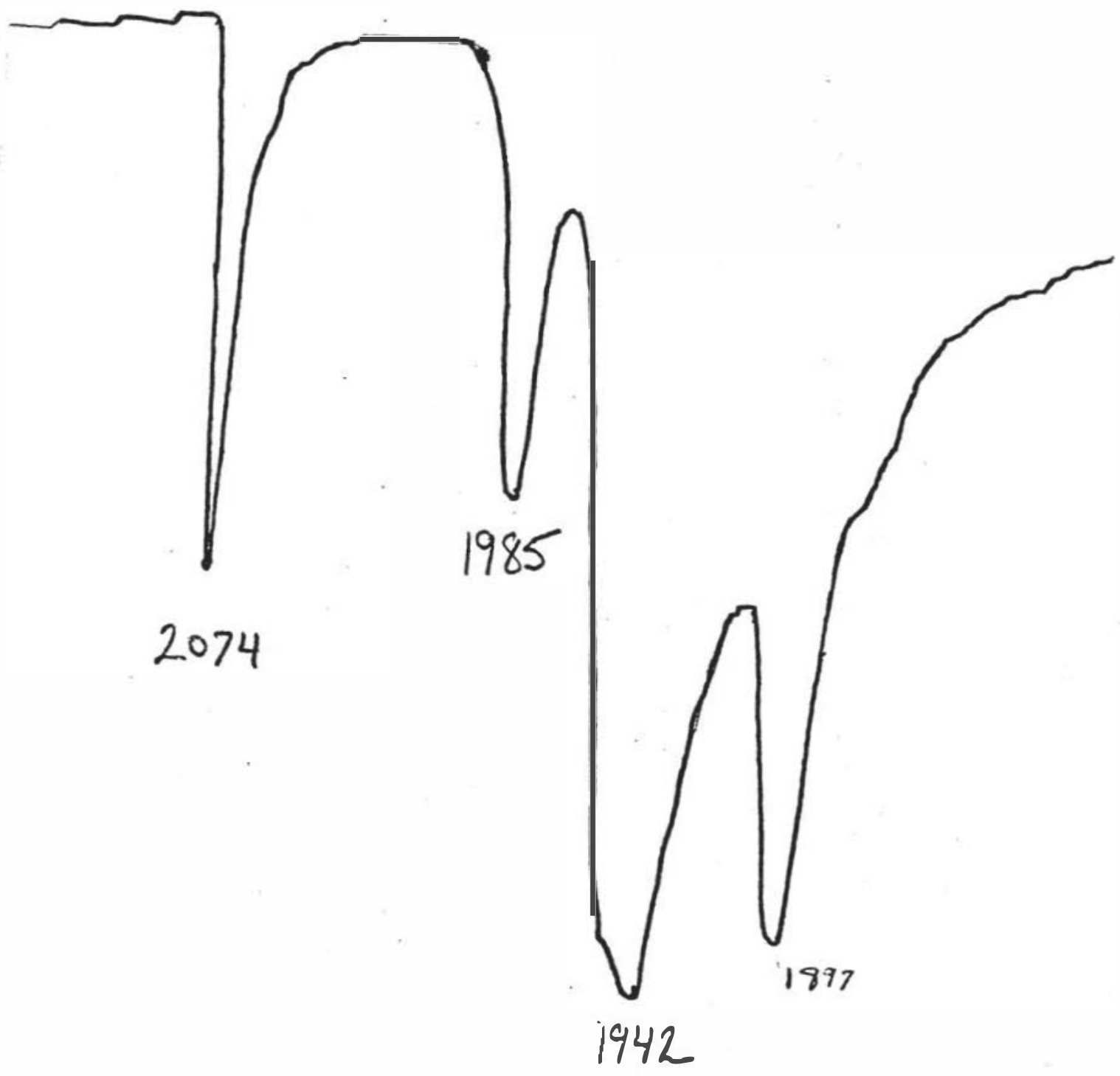




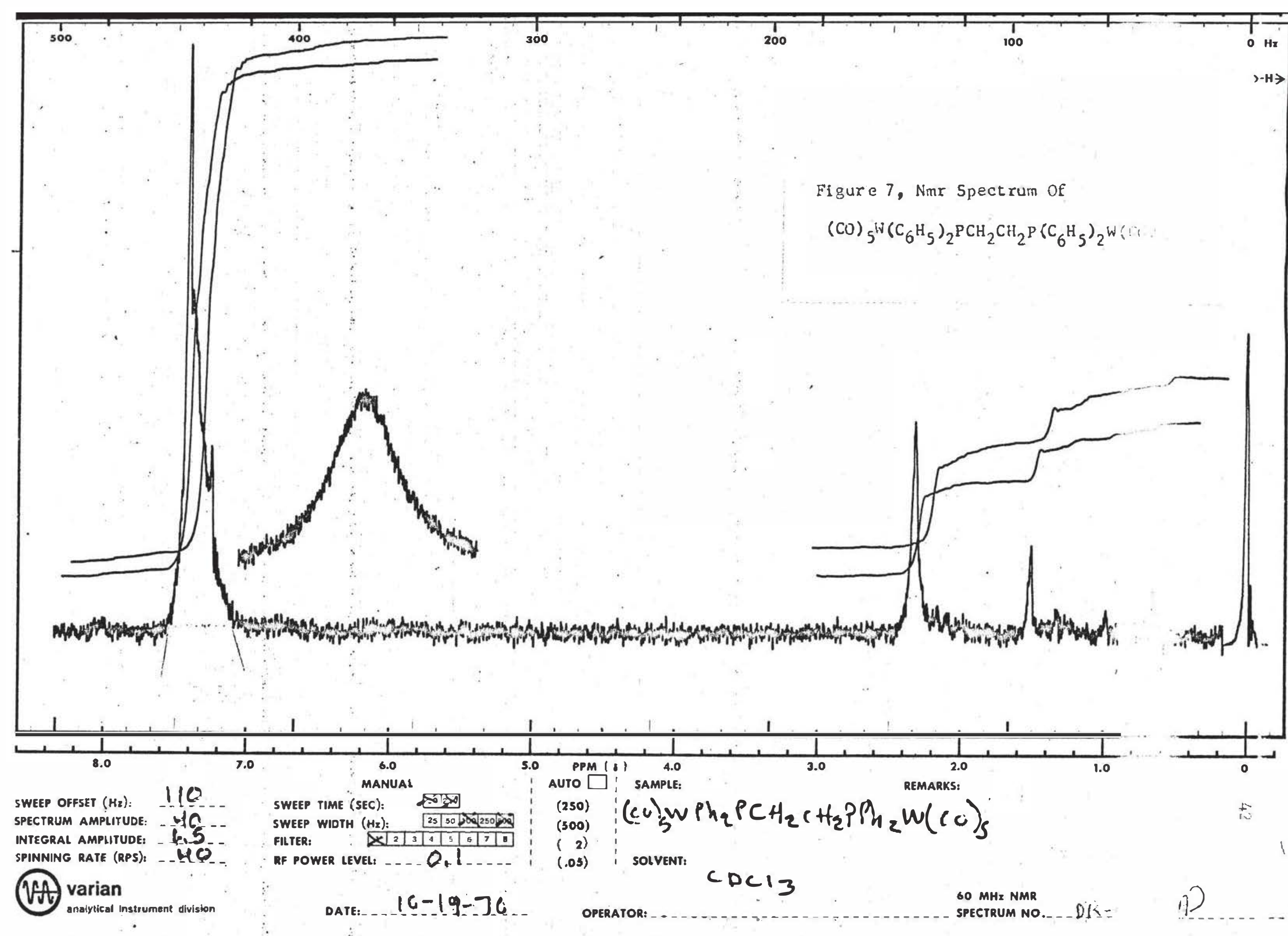




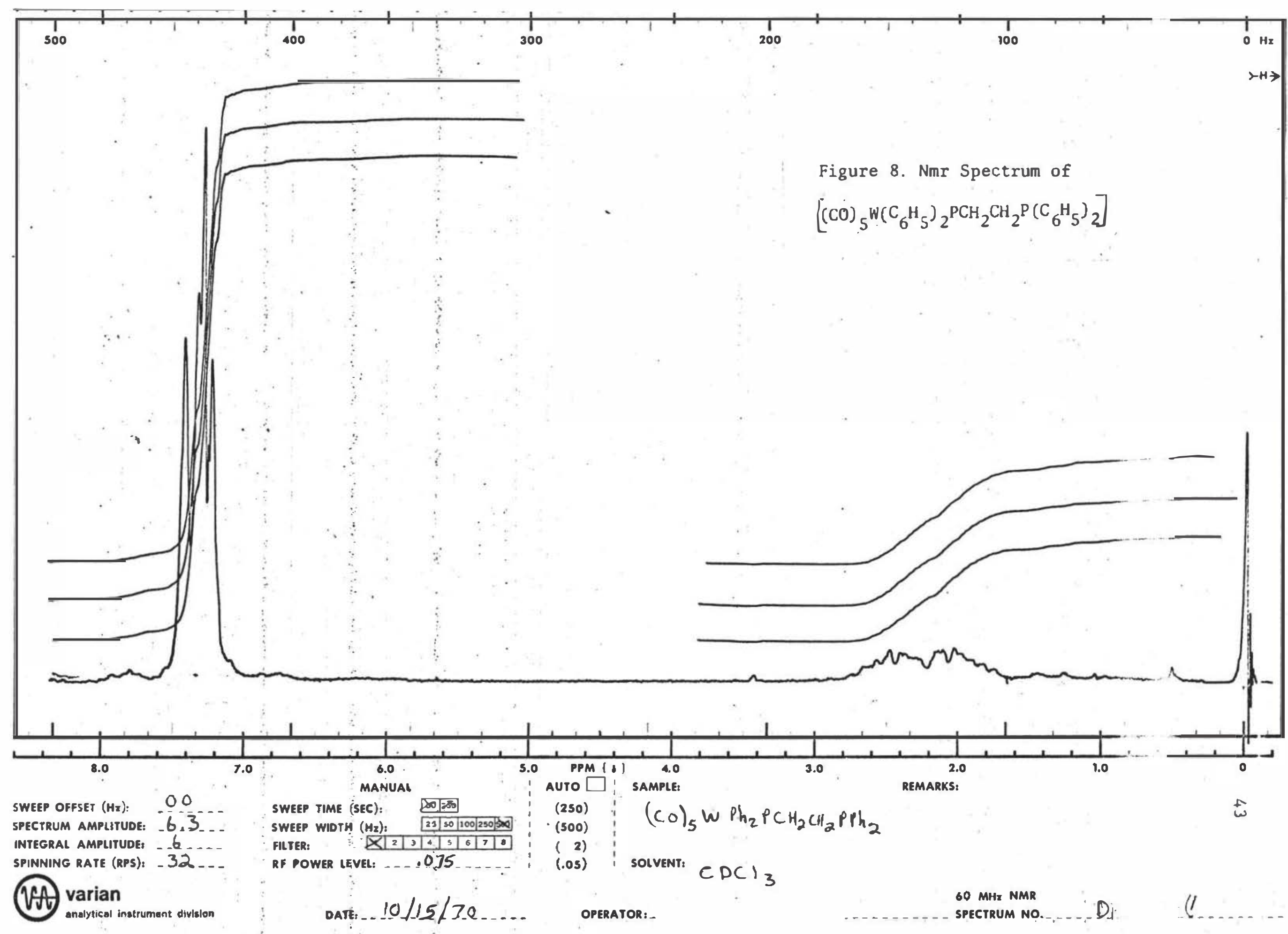




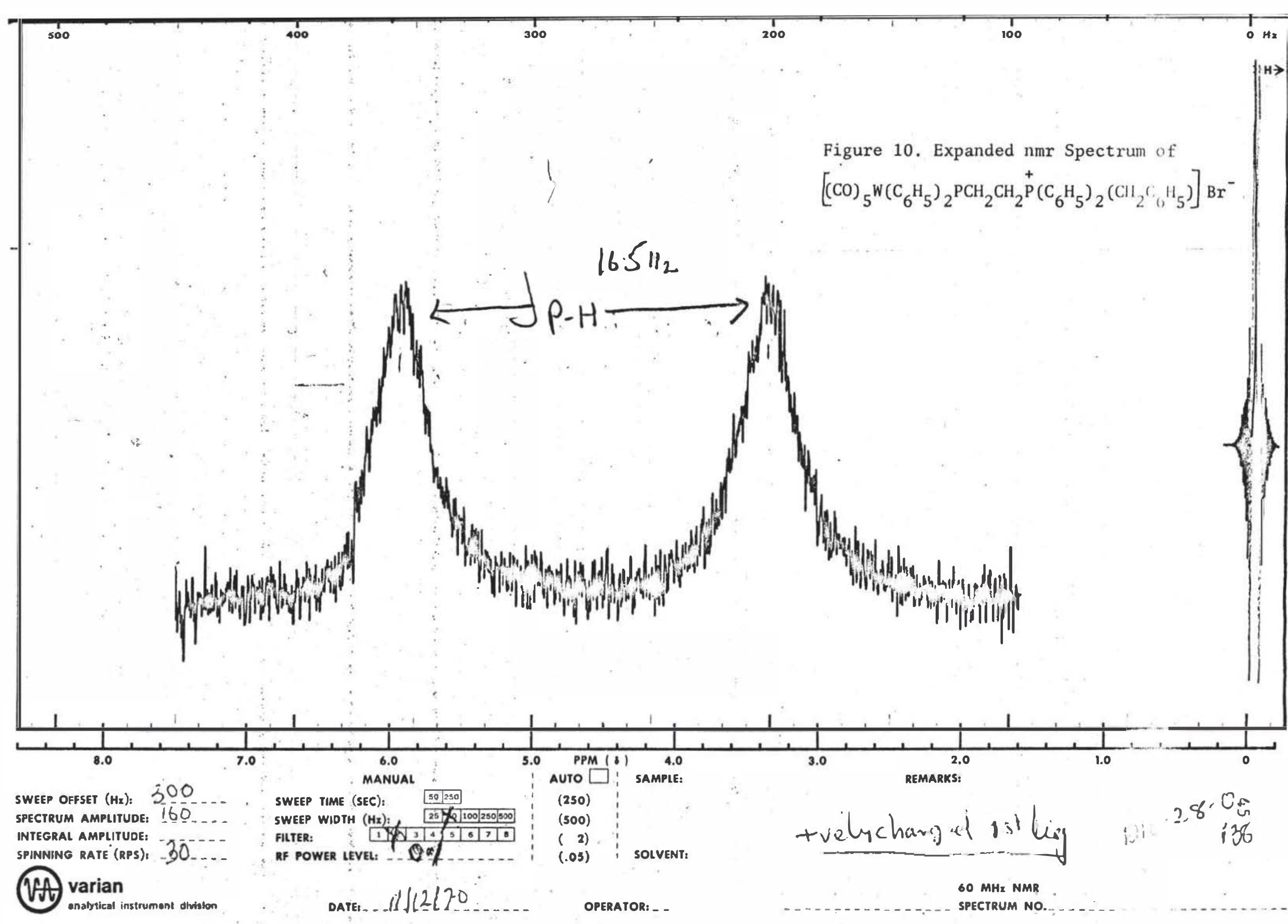




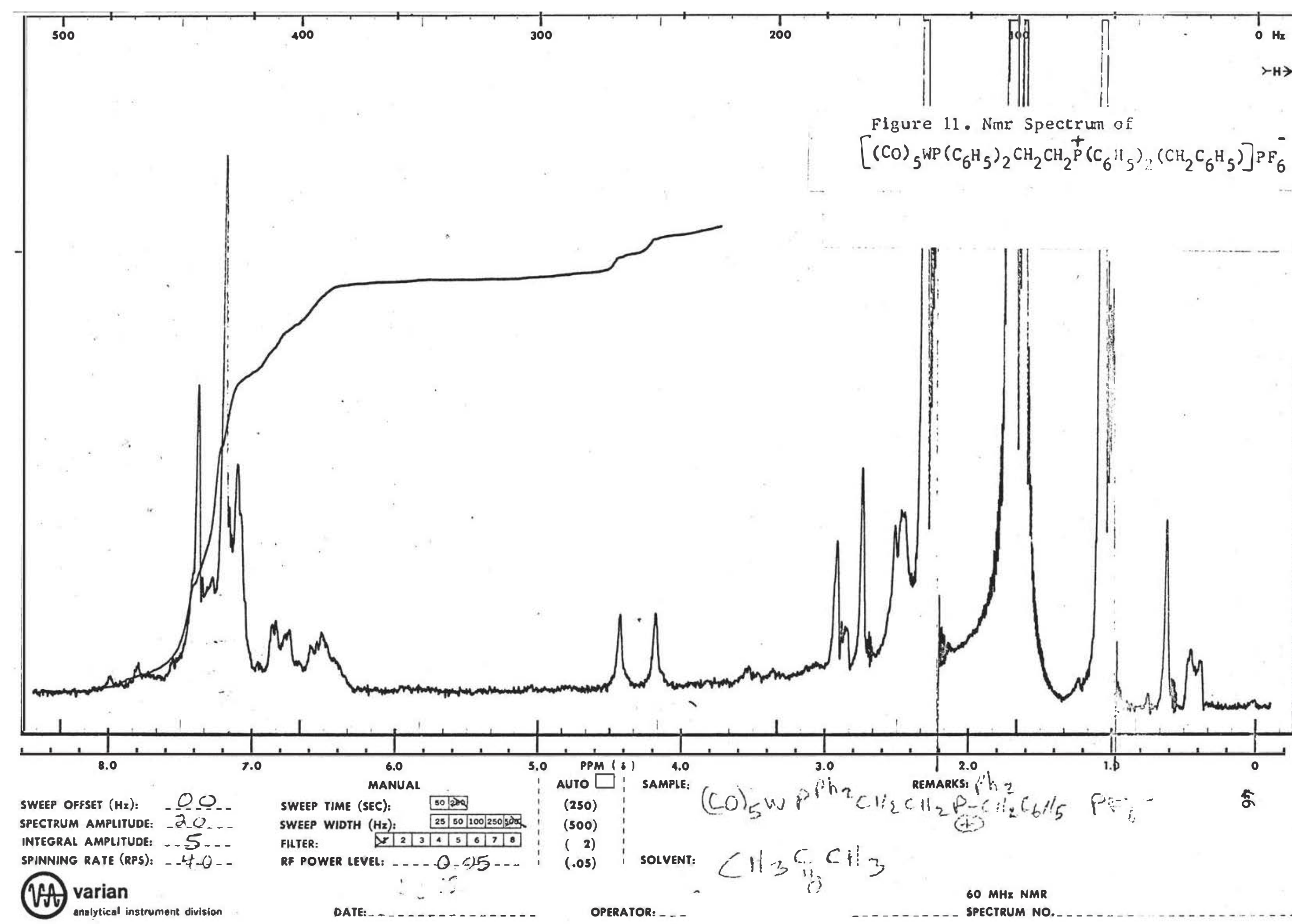




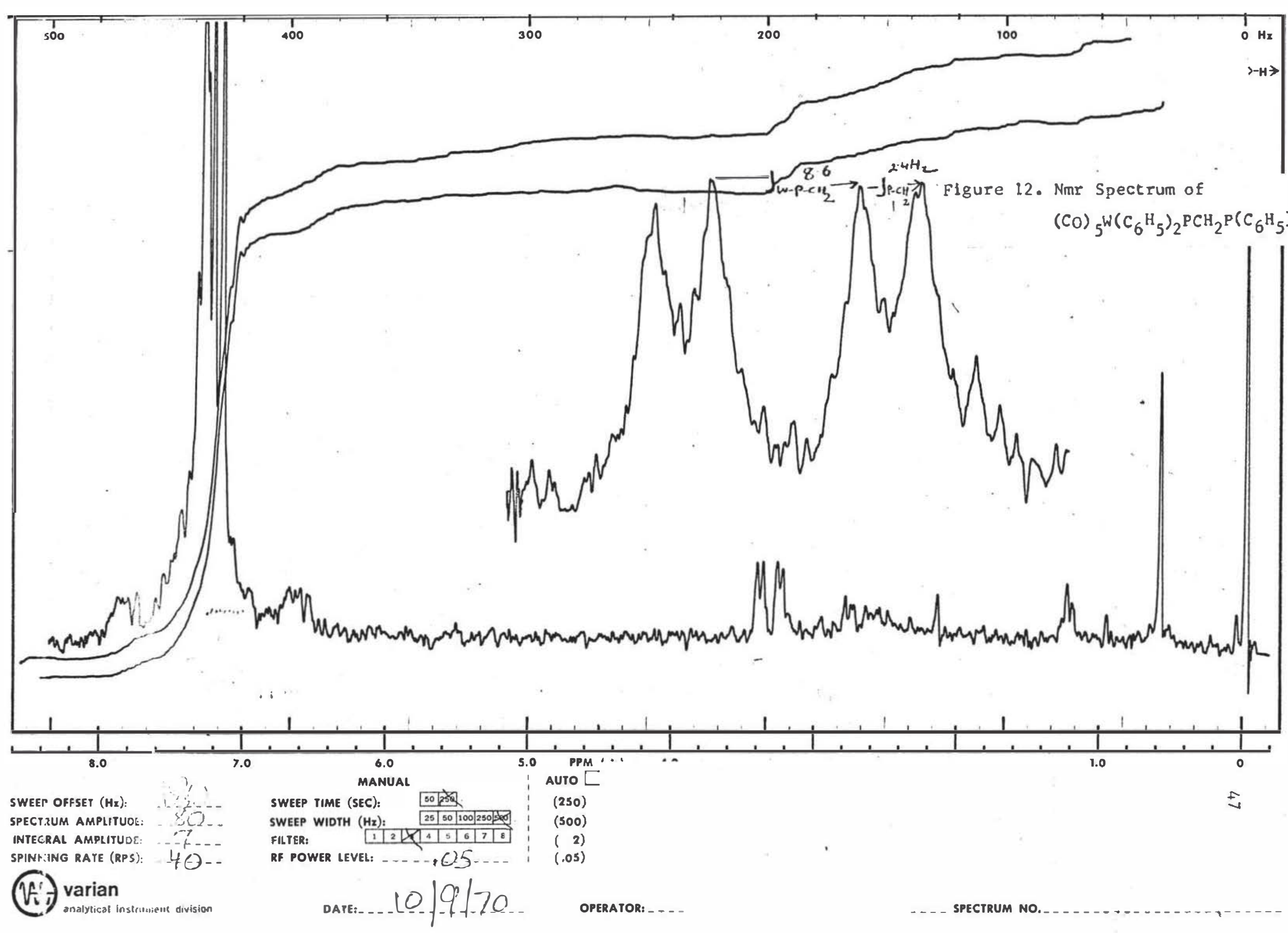



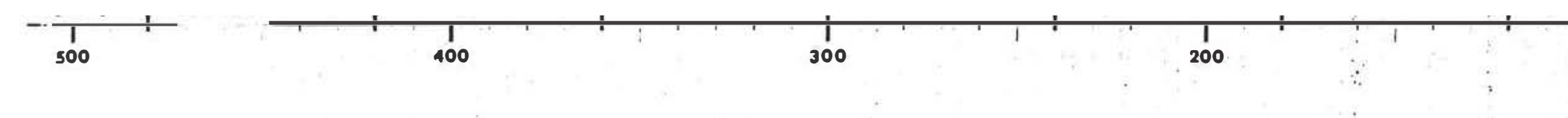

$1_{100}^{1}$

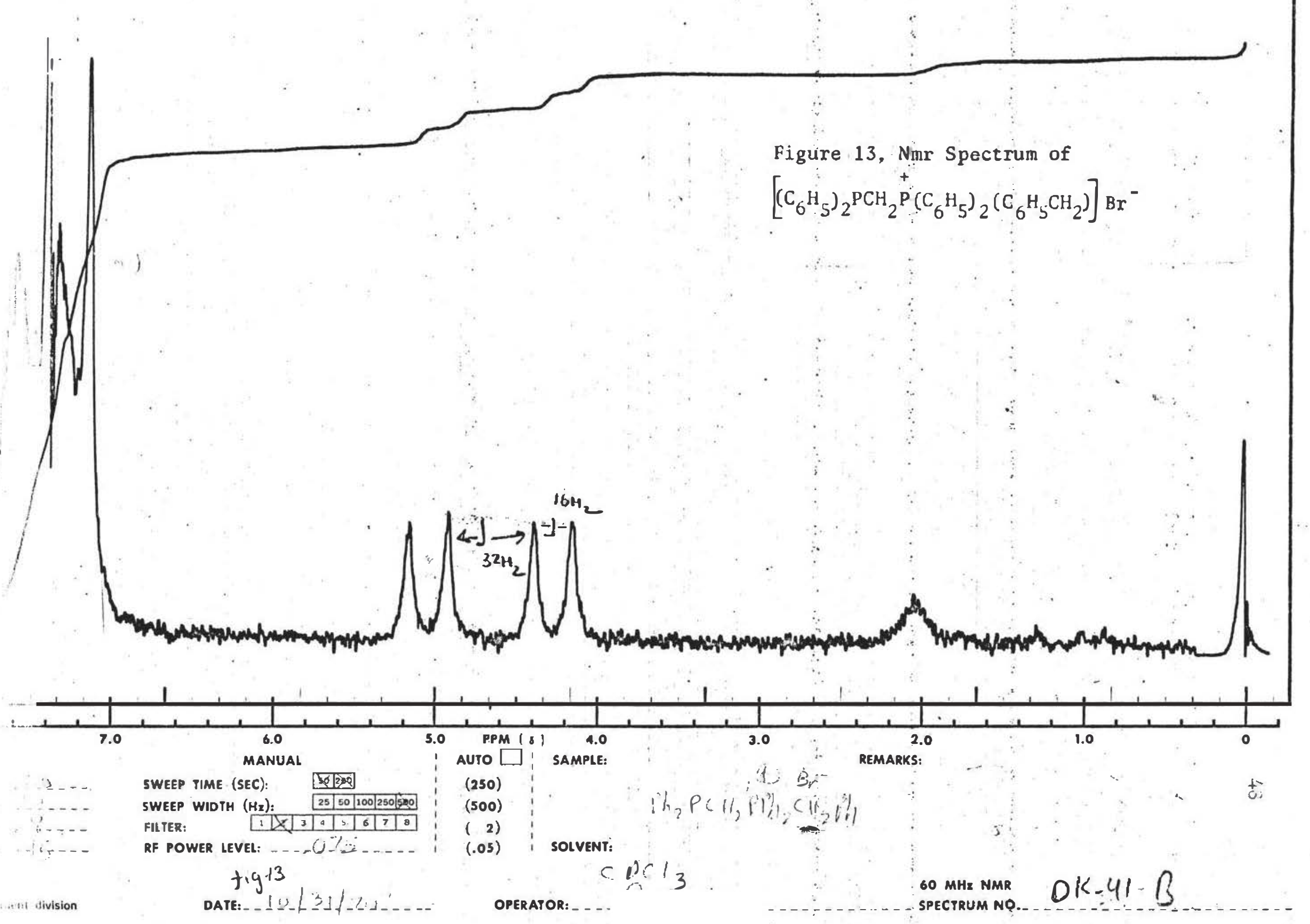

SWEIP OFFSET ( $\mathrm{Hz}_{\mathbf{z}}$; PEEC RUM AMPLITUC: INTE ;RAL AMPLITUI; SPIN JING RATE (R): $(V$.$) varian$

$$
\begin{aligned}
& f i g 13 \\
& \text { Operator: } 13
\end{aligned}
$$

60 MHz NMR
SPECTRUM NO.. 


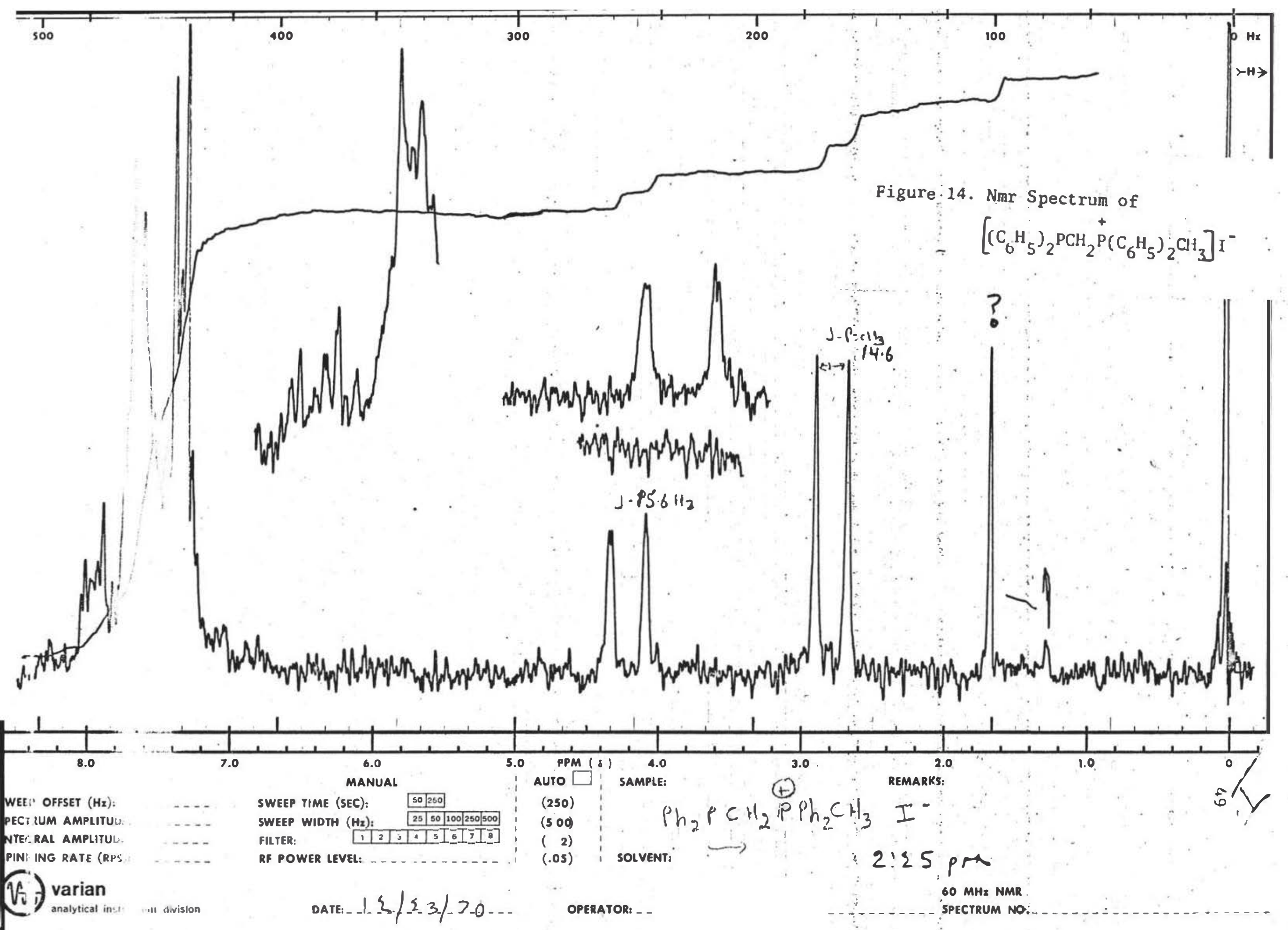




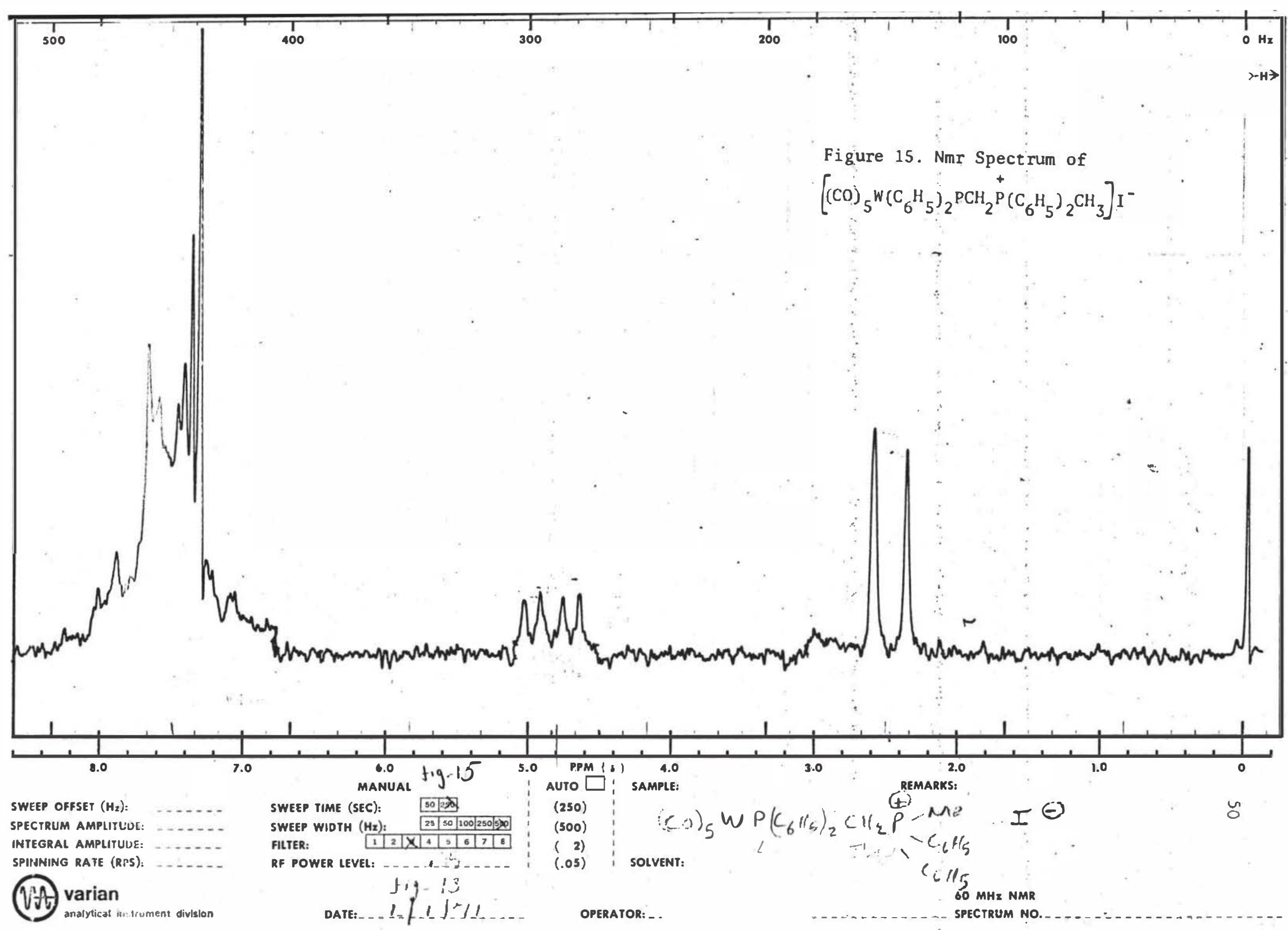




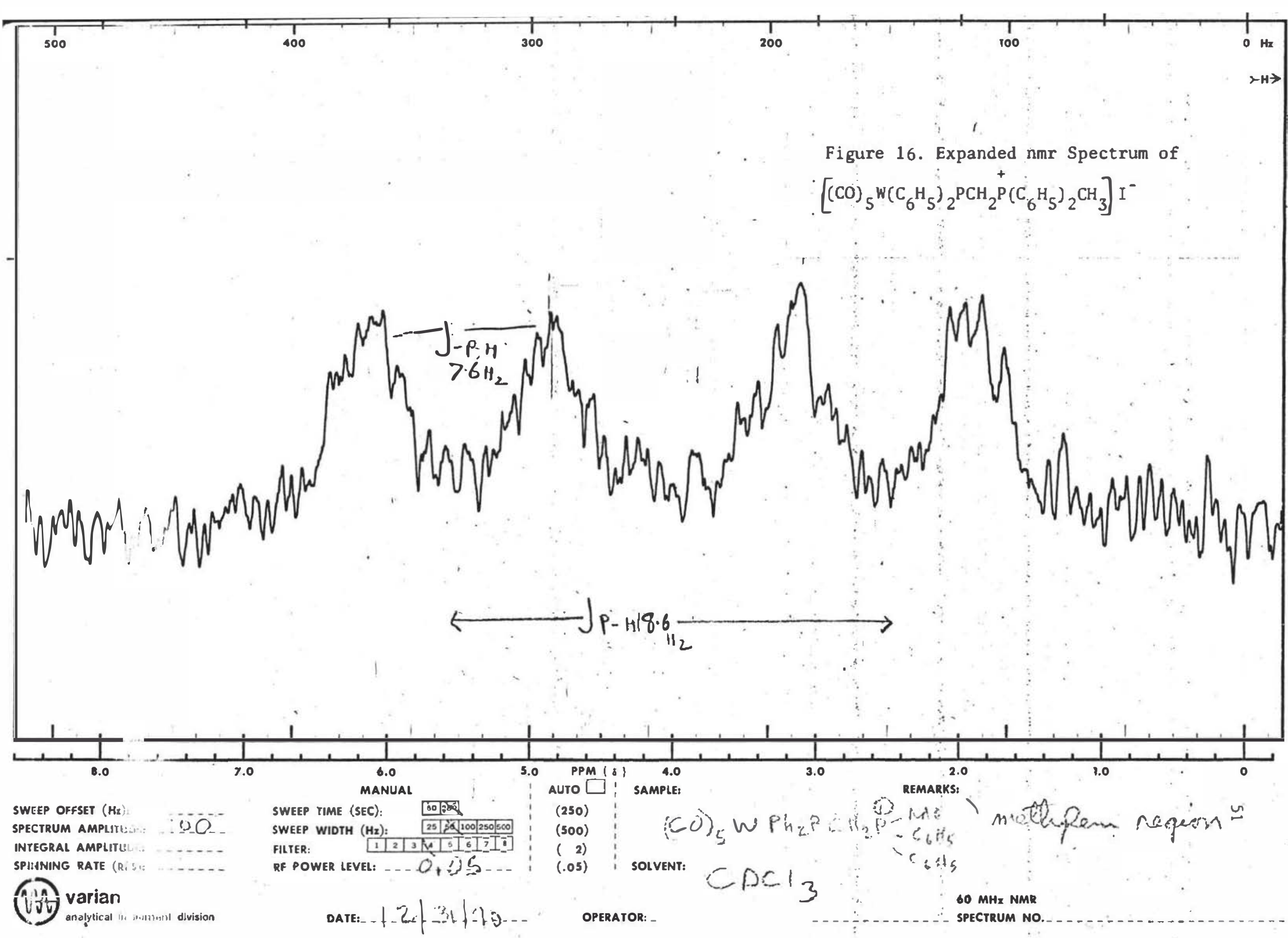




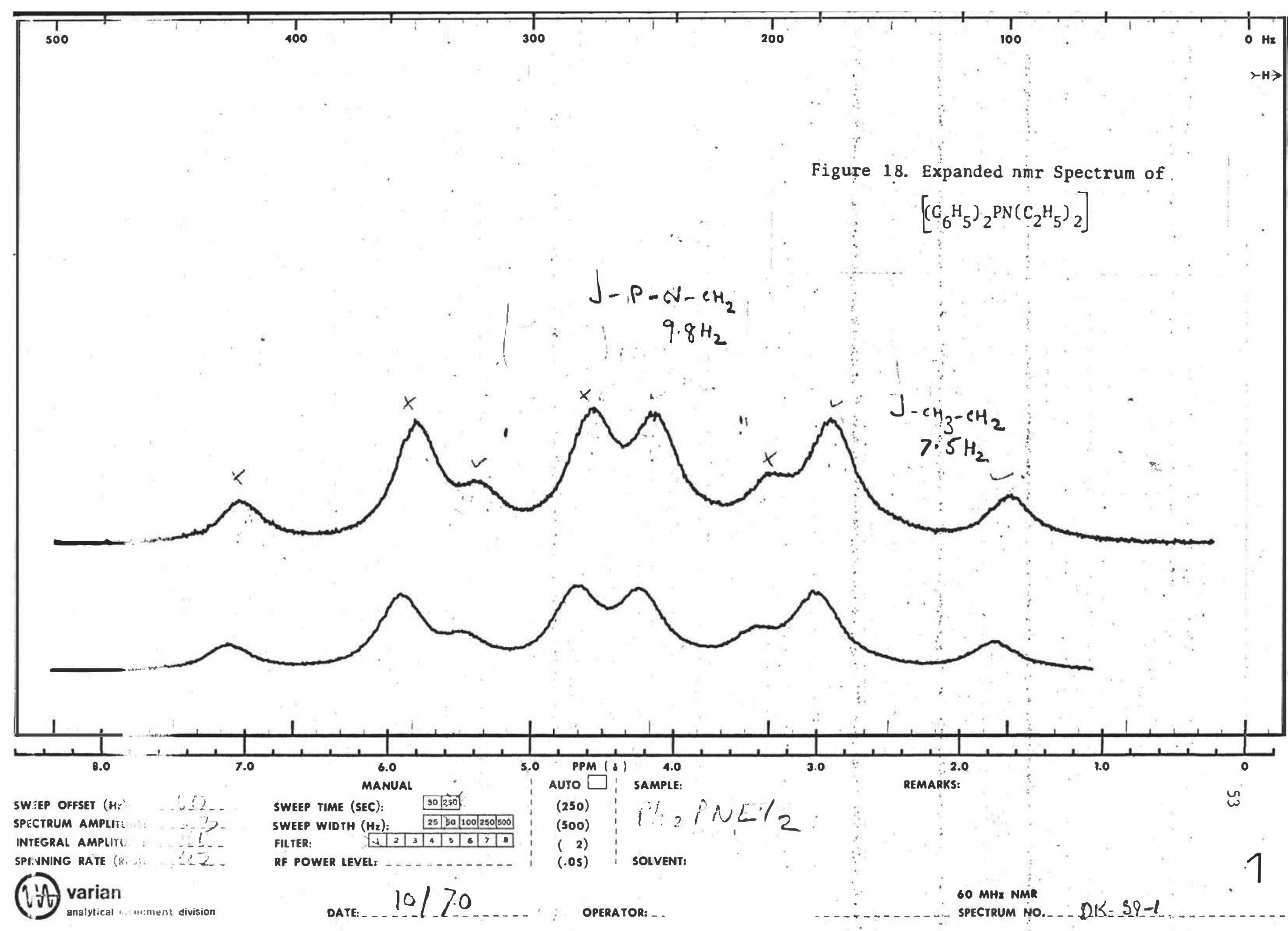




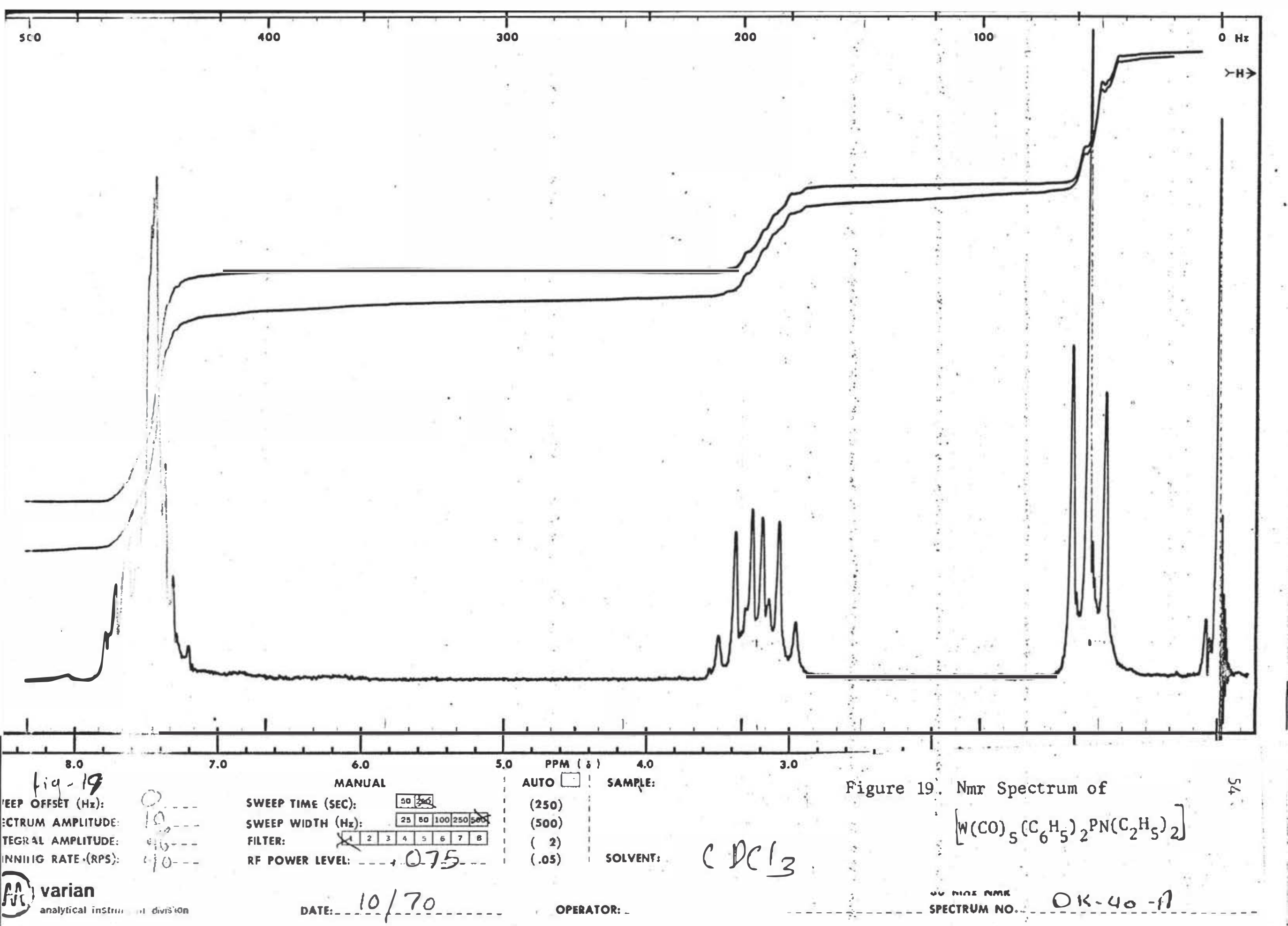




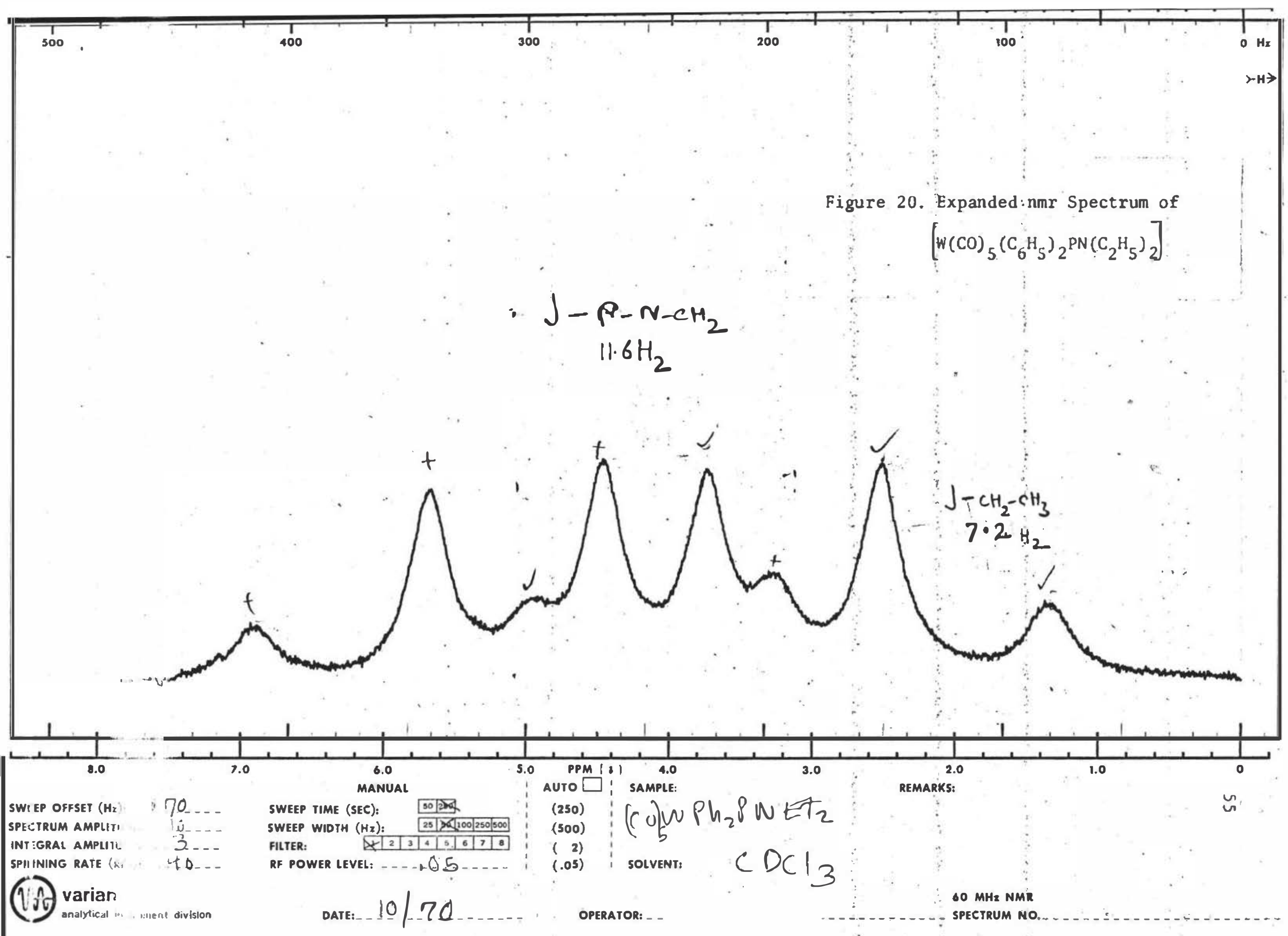




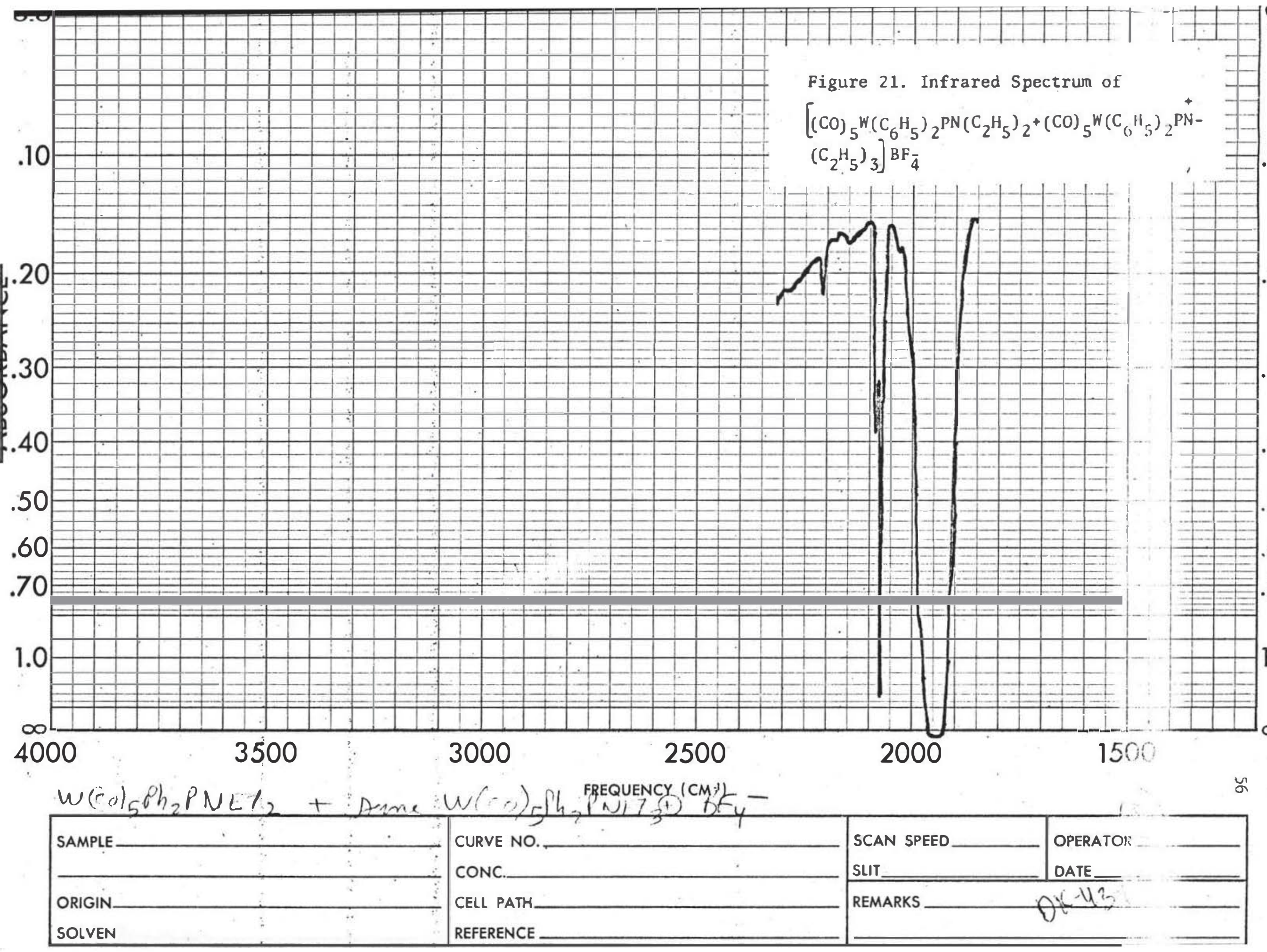




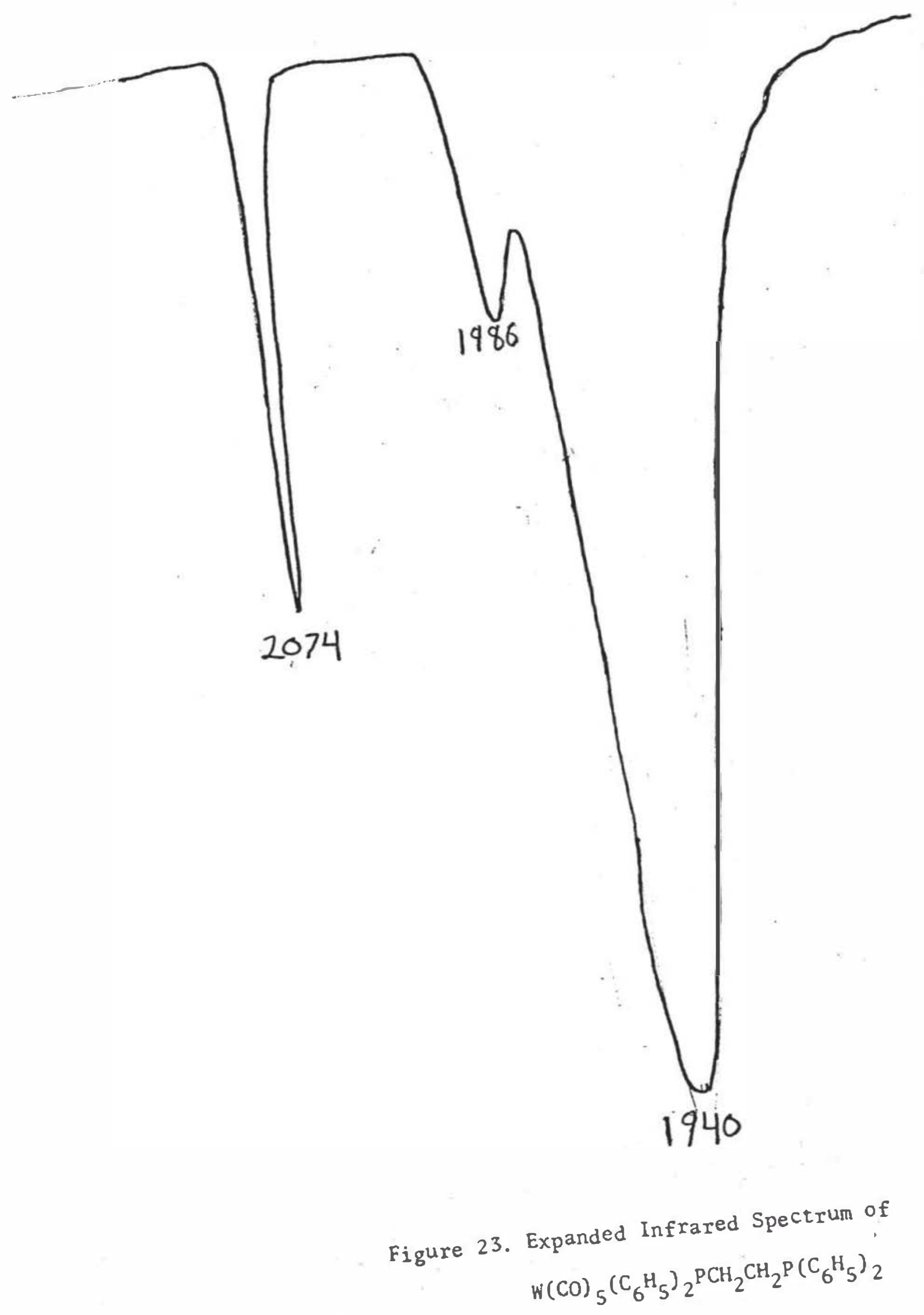




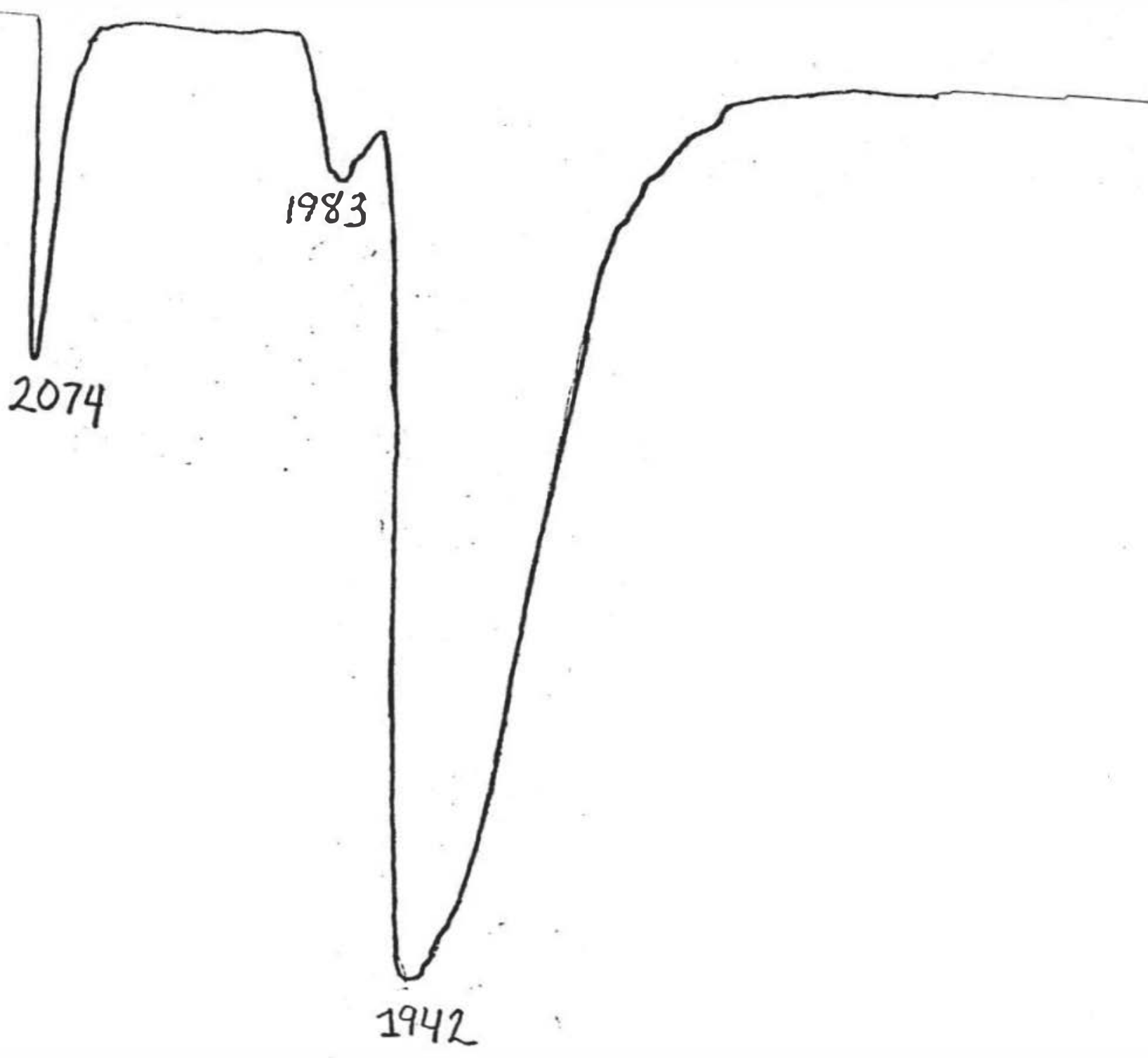

Figure 24. Expanded Infrared spectrum of $(\mathrm{CO})_{5} \mathrm{~W}\left(\mathrm{C}_{6} \mathrm{H}_{5}\right)_{2} \mathrm{PCH}_{2} \mathrm{CH}_{2} \mathrm{P}\left(\mathrm{C}_{6 \mathrm{H}_{5}}\right)_{2} \mathrm{~W}(\mathrm{CO})_{5}$ 


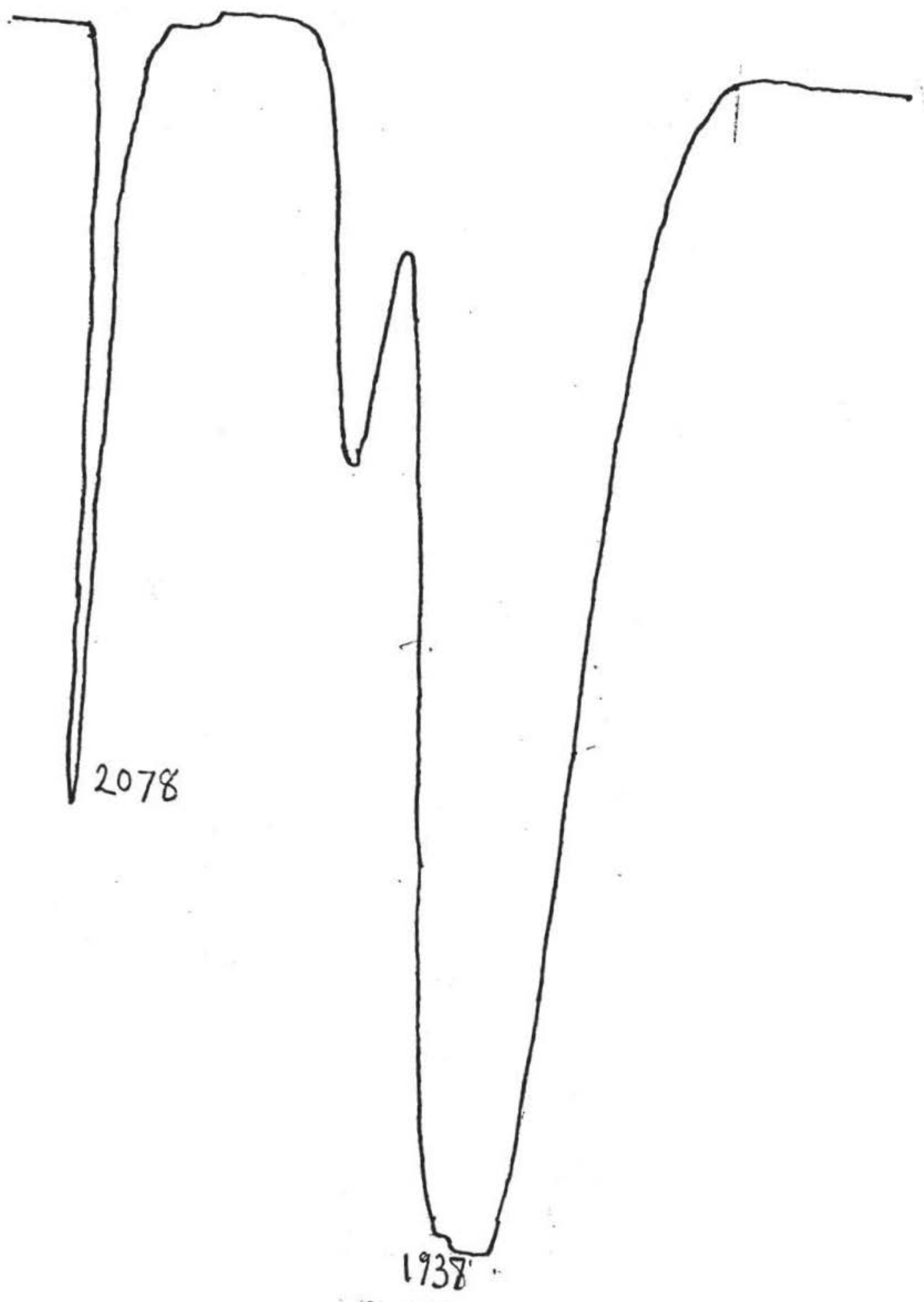

Figure 25. Expanded Infrared Spectrum of

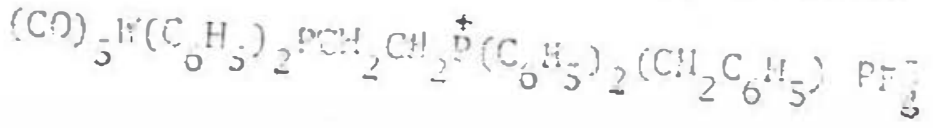




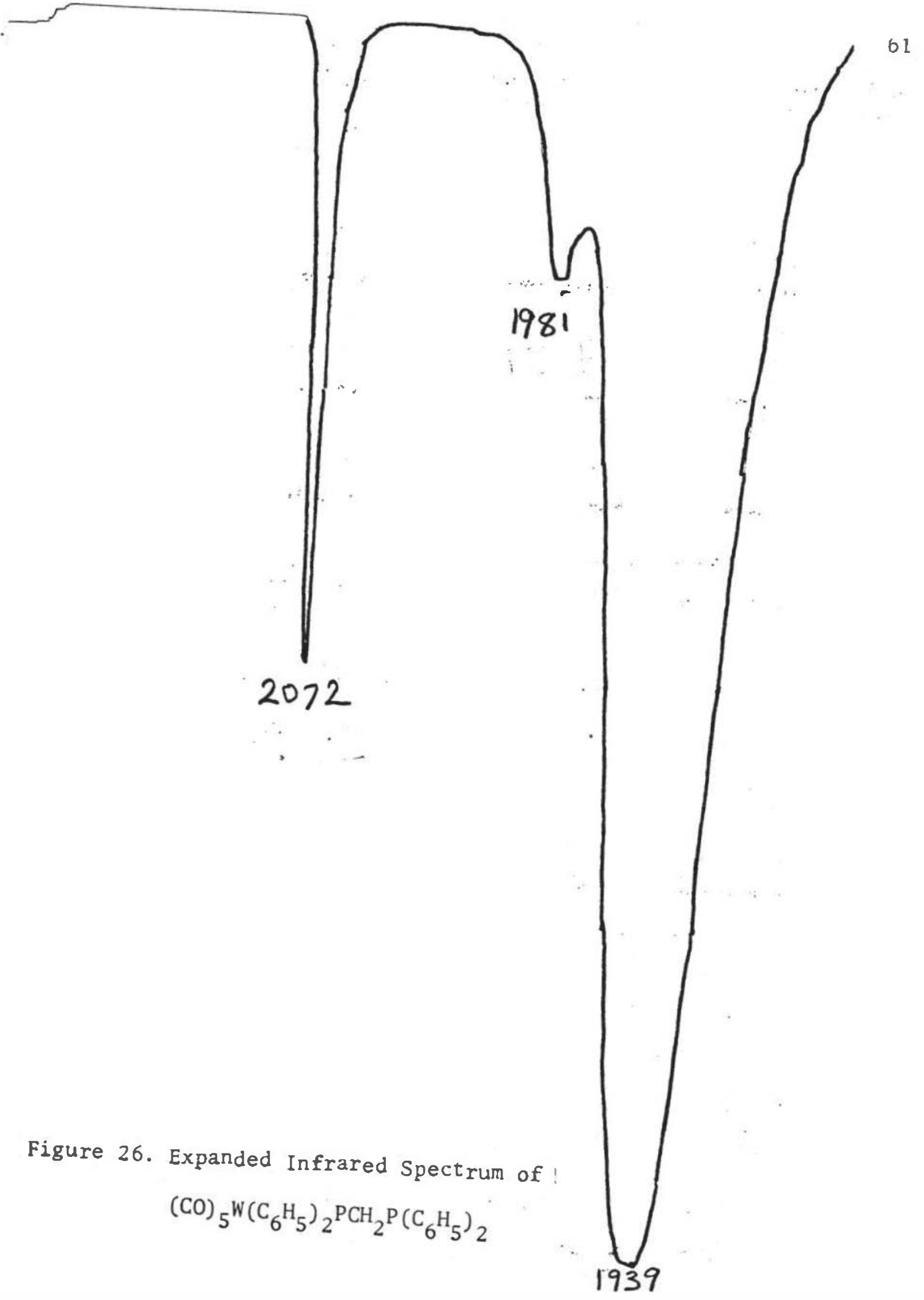




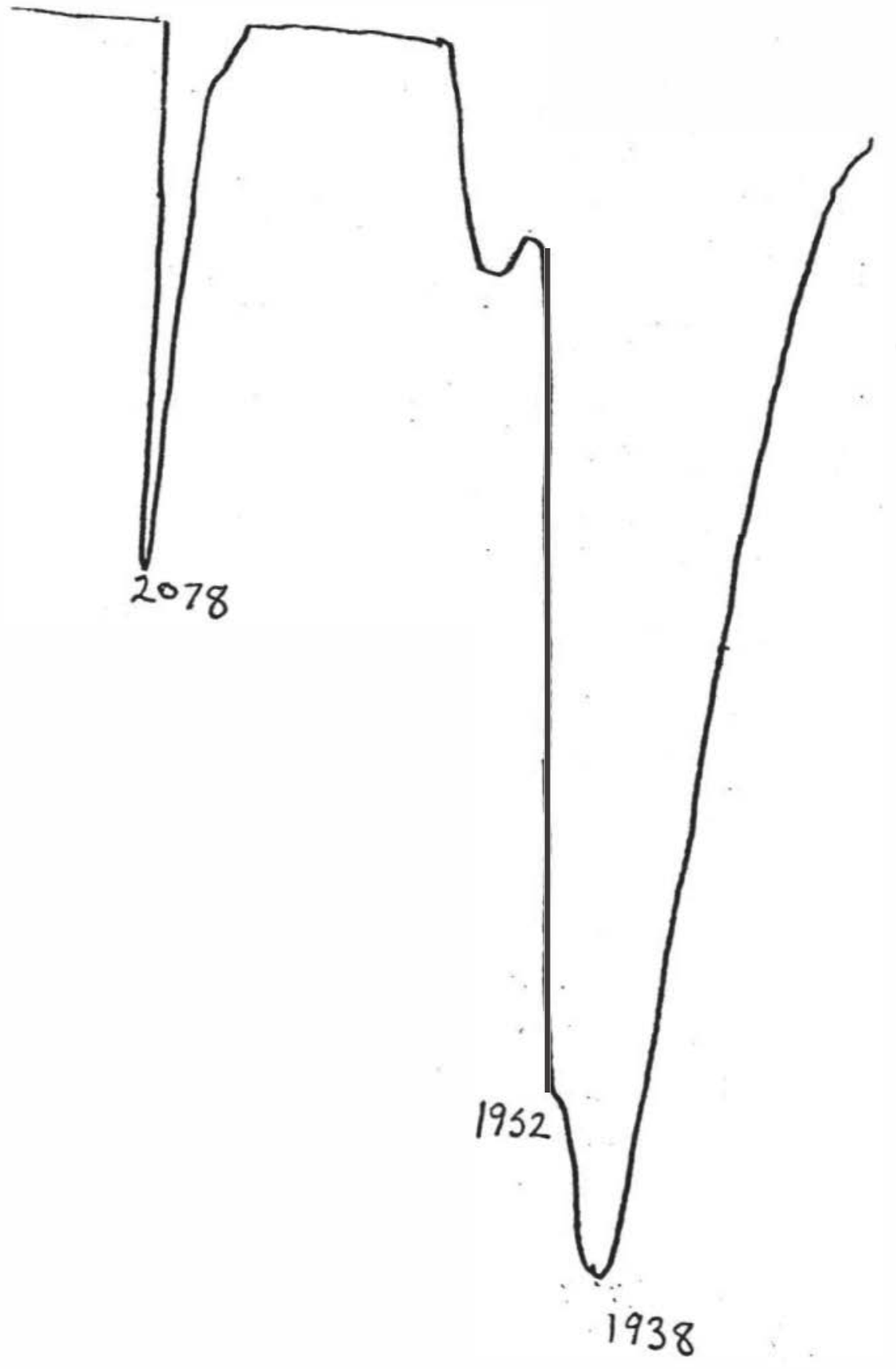

Figure 27. Expanded Infrared Spectrum of
(CO) ${ }_{5}{ }^{W}\left(\mathrm{C}_{6} \mathrm{H}_{5}\right)_{2}{ }_{2} \mathrm{PCH}_{2} \stackrel{+}{\mathrm{P}}\left(\mathrm{C}_{6} \mathrm{H}_{5}\right)_{2}\left(\mathrm{CH}_{3}\right) \mathrm{I}^{-}$ 
53

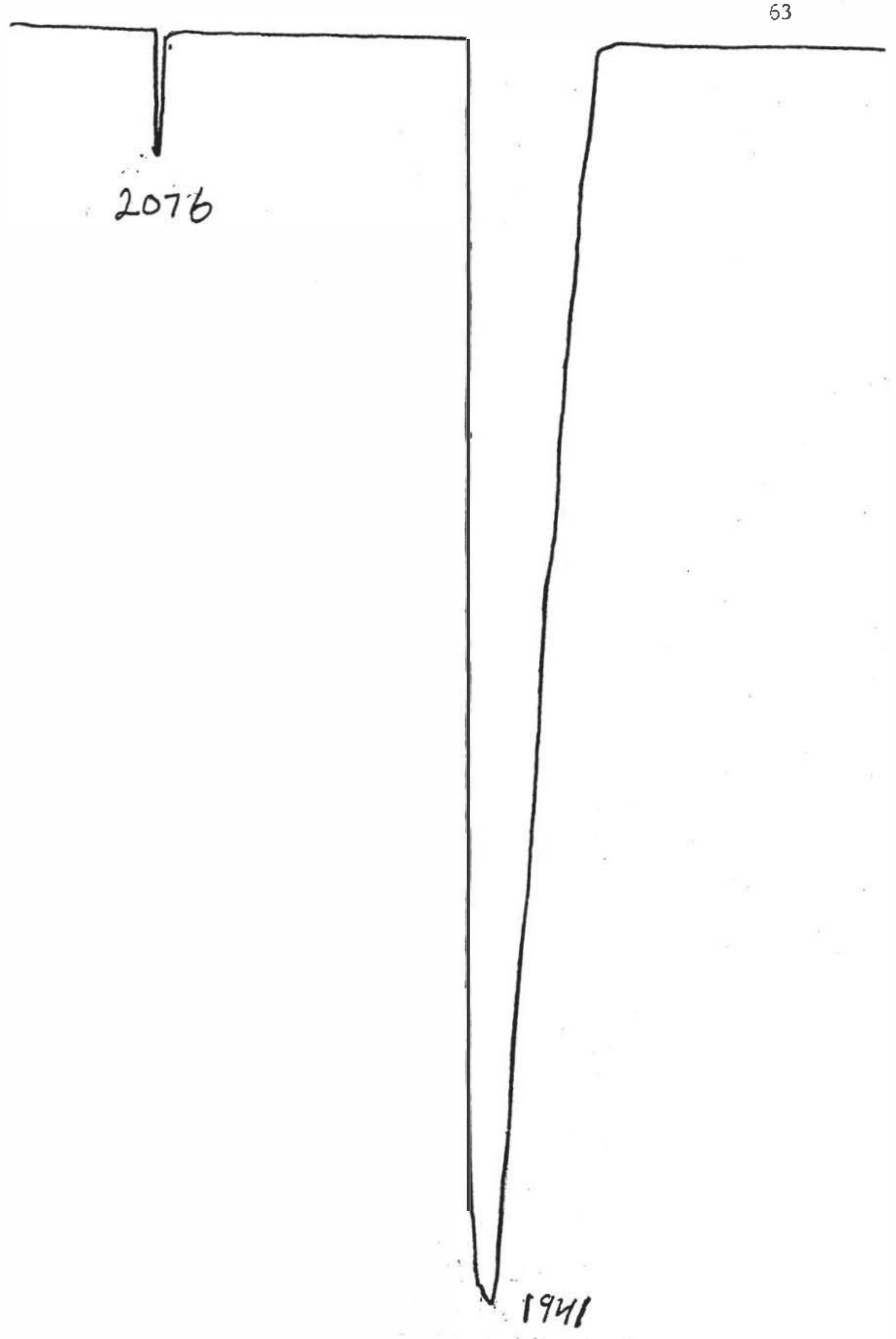

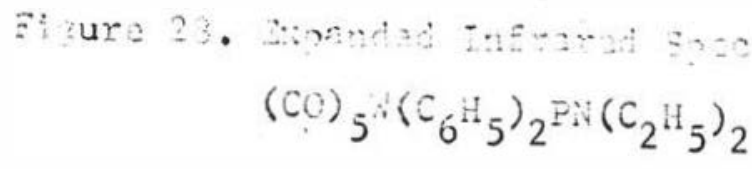




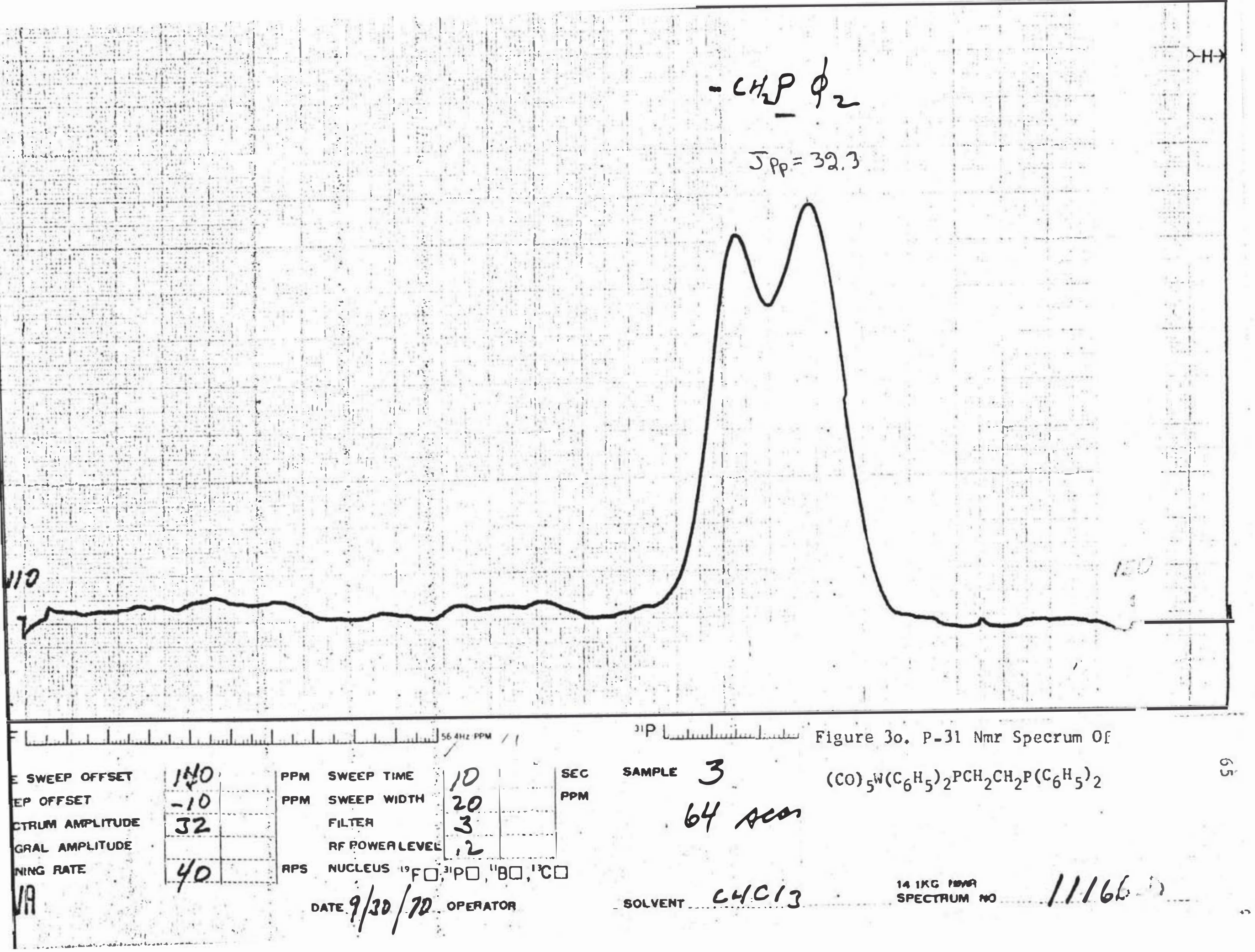




\section{BIBLIOGRAPHY}

1. R. J. Angelici and Sr. M. D. Malone, Inorg. Chem., 6, 1731 (1967)

2. H. J. Plastas, J. M. Stewart and S. O. Grim, J. Am. Chem. Soc., 21. 4326 (1969)

3. F. B. Ogilvie, R. L. Keiter, G. Wulfsburg and J. G. Verkade, Inore. Chem., $\underline{8}, 2346$ (1969)

4. R. L. Keiter and J. G. Verkade, Inorg. Chem., 8, 2115 (1969)

5. C. S. Kraihanzel, F. A. Cotton, Inorg. Chem., 2, 533 (1963)

6. D. Bergland and D. W. Meek, J. Am. Chem. Soc., 20, 518 (1968)

7. R. D. Bertrand, D. A. Allison and J. G. Verkade, J. Am. Chem. Soc., 22, 71 (1970)

8. E. Ercolani, J. V. Quagliano and L. M. Venanzi, Inorg. Chem. Acta, 13:31, 421 (1969)

9. D. Bergland and D. W. Meek, Inorg. Chem., 8, 2603 (1969)

10. J. Chatt and F. A. Hart, J. Chem. Soc., 1378 (1960)

11. A. M. Aguiar, S. Beisler and A. Mills, J. Org. Chem., 2?. 1001 (1962)

12. W. Hewartson and 月. R. Watson, J. Chem. Soc., 1940 (1962)

13. W. Kuchen and H. Buchwald, Chem. Ber., 21, 2871 (1958)

14. G. Ewart. D. S. Payne, A. L. Port and in part A. P. Iane, J. Chem. Soc., 3984 (1962)

15. E. O. Fisher and K. Ofele, Chem. Ber., 93, 1556 (1960)

16. H. Behrens and H. Zielsperger, 2. Naturforsch., 166, 349 (1961)

17. S. O. Grim, D. A. Wheatland and W. KicFarlane, J. Am. Chem. Soc., 89. 5773 (1967) 
18. D. A. Wheatland, Ph. D. Dissertation, "Tertiary Phosphine Derivatives of the Group VI Metal Carbonyls" University of Maryland (1967)

19. E. J. Corey, ed., "Organic Synthesis," Vol. 46, John Wiley and Sons, Inc.. New York (1966), 113 
LEVEL I8 $\quad \cdots \quad$ MAIN DATE $=70286$

$11 / 23 / 29$

C THIS RESEARCH IS DONE UNDER THE DIRECTION OF DR• R.L. KEITER.

C DK- - - REPRESENTS COMPOUNDS MR.DILIP P. SHAH HAS MADE IN THE LAB

C WE WILL ALSO HAVE THREEE EXTRA VALUES OF K'S WHICH ARE DUE TO QUADRATI1

C EQATIONS

C : THIS PROGRAME IS TO CALCULATE FORCE CONSTANTS.

C VI (I) IS ASSUMED TO BE HIGHER BY +5 CM-1 THEN A(E) AS IT IS UNRESOLVED

$C$ VII) IS A FRQUENCY DUE" TO C-O "WICH" IS TRANS TO THE IGAND $\cdots$

C V 1 (2)IS A FRQUENCY DUE TO C-O WICH IS INERACTING BETWEEN TRANS AND CI

C VIE) IS A FRQUENCY DUE TO C-O WICH IS EQITORIAL TO THE LIGAND

C WE WILL BE CALCULATING FORCE CONST, OF MONOSUBSTITUTED COMPLEXES

C... ALL THE DATA: FOR ONE COMPOUND SHOULD BE PUNCHEO OU. THE SAME. CARQ

C ALL THE FRQUENCIES ON DATA CARDS ARE PUNCED FOLLOWING WAY

C FIRST ONE IS PUNCHEO IN ONE TO TEN.

C SECOND ONE IS PUNCHED FROM 11 TO 20.

C. THIRD ONE WILL BE. PUNGEED FROM 21.T. 30

-C COMPOUND REF. SHOULD BE PUNCHED FROM 31 TO 35.

C LAST CARO OF THE DATA SHOULD HAVE 9999.9 FROM 1 TO6.

C GO MAN GO •

C. SOCK TO YOU

C WE THANK MR. LARRY SHEDWICK FOR HIS HELP IN MODIFY ING THIS PROGRAME.

DOUBLE PREC ISION CNO

REAL LCON,LAI, LA2, LE, KIPOS,KINEG,KI, K2,KIN,K $2 N$

TRIP $=9999.9$

. $\angle C O N=5.8890 E-2$

$U=0.14583$

WR ITE $(6,100)$

IOO FORMAT('IFORCE CONSTANT CALCULAAION OF W(CO) 5L \& W(CO) $5 L W(C O) 5$

1 BY MR. DILIP SHAH FOR HIS M.S RESEARCH' /// ' V 1 V

$2 \mathrm{~K}+\mathrm{K} \quad \mathrm{K}$

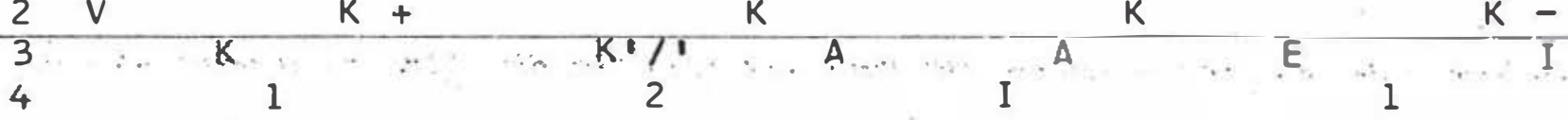

$52(/ / /)$

C CNO REPRESENTS THE REF - OF COMPLEXES

3 READ $(5,101)$ VSUBA 1 , VSUBA $2, V S U B E, C N O$

101 FORMAT $(3 F 10.1, A 6$.

IF (VSUBAI=TRIP) I, 9,1

$1 L A I=L C O N \because V S U B A I \div 2$

LA $2=L C O N * V S U B A 2 \% \approx 2$

$[E=[C O N * V S U B E * 2$

$A=40 \% U \% 2 \%(L A 1-L A 2)$

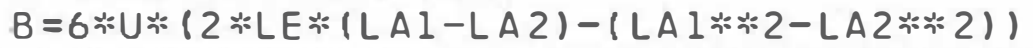

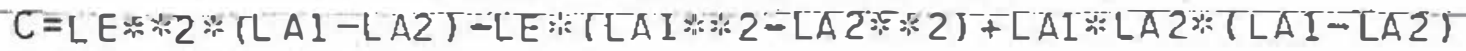

ROOT =B $* 2 \div 2-4 \div A=C$

IF (ROOT ) $8,2,2$

$R I P O S=(-B+S R R T(R O O T)) /(2 * A T$

$K I N E G=(-B-S Q R T(R O O T)) /(2 \% A)$

$\mathrm{KI}=0$

$K 2=0$

Appendix I Comouter programine for

calculation of force

con?stints 


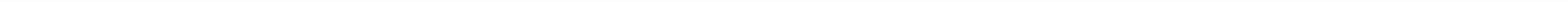




\section{Vita}

Name: Dilip Poonamchand Shah

Permanent Address: 1160 East Route 36. Apt. \# 5, Urbana, Ohio

Degree and Date to be Conferred: M. S. (Chemistry)

February, 1971

Date of Birth: December 13, 1945

Place of Birth: Bombay. India

Secondary Education: Matriculation from the B.K.H. School Bombay. India, March 1962

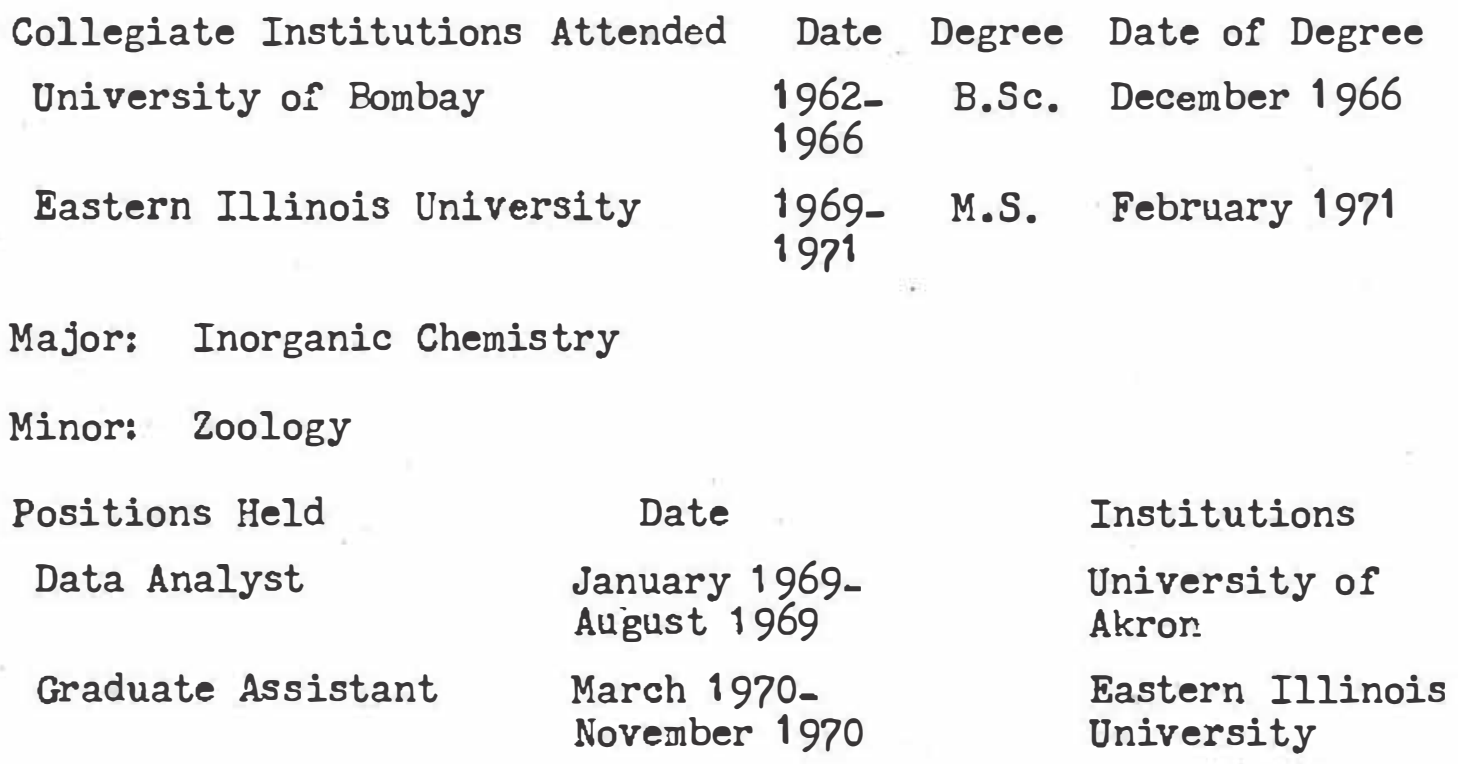

